In cooperation with the Wisconsin Department of Natural Resources

\title{
Hydrology, Nutrient Concentrations, and Nutrient Yields in Nearshore Areas of Four Lakes in Northern Wisconsin, 1999-2001
}

Kentuck Lake
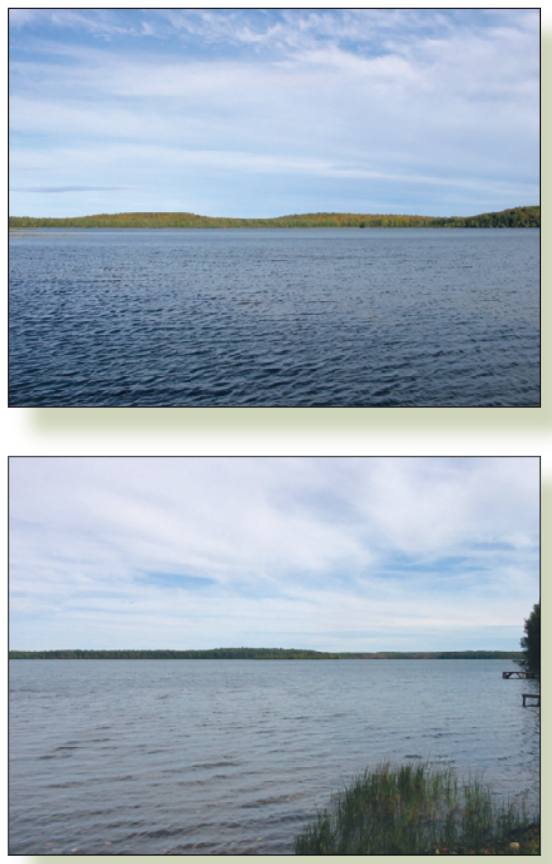

Butternut Lake
Lower Ninemile Lake
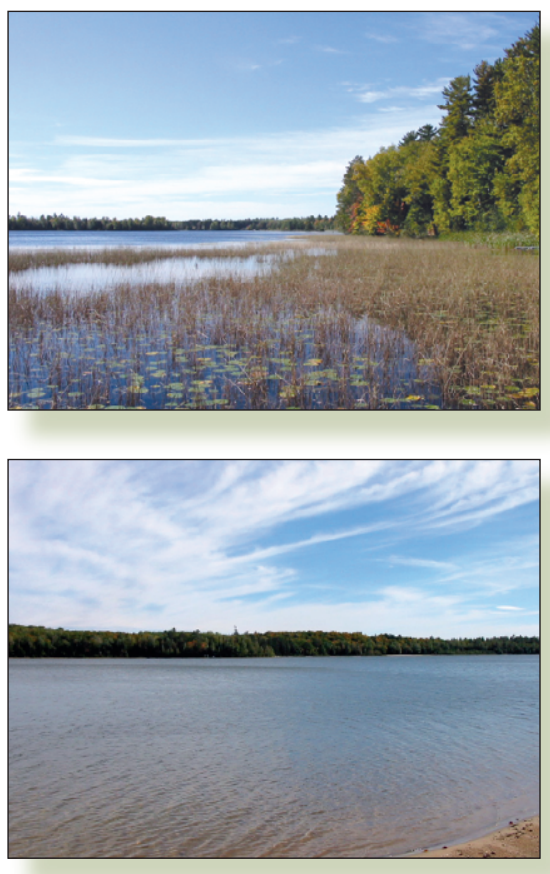

Anvil Lake

Water-Resources Investigations Report 03-4144 


\section{Hydrology, Nutrient Concentrations, and Nutrient Yields in Nearshore Areas of Four Lakes in Northern Wisconsin, 1999-2001}

By David J. Graczyk', Randall J. Hunt ${ }^{1}$, Steven R. Greb², Cheryl A. Buchwald ${ }^{1}$, and James T. Krohelski ${ }^{1}$

In cooperation with the Wisconsin Department of Natural Resources

${ }^{1}$ U.S. Geological Survey, ${ }^{2}$ Wisconsin Department of Natural Resources

Water-Resources Investigations Report 03-4144 


\title{
U.S. Department of the Interior \\ Gale A. Norton, Secretary \\ U.S. Geological Survey \\ Charles G. Groat, Director
}

U.S. Geological Survey, Reston, Virginia: 2003

\author{
For sale by U.S. Geological Survey, Information Services \\ Box 25286, Denver Federal Center \\ Denver, CO 80225 \\ For more information about the USGS and its products: \\ Telephone: 1-888-ASK-USGS \\ World Wide Web: http://www.usgs.gov/
}

Any use of trade, product, or firm names in this publication is for descriptive purposes only and does not imply endorsement by the U.S. Government. 


\section{Contents}

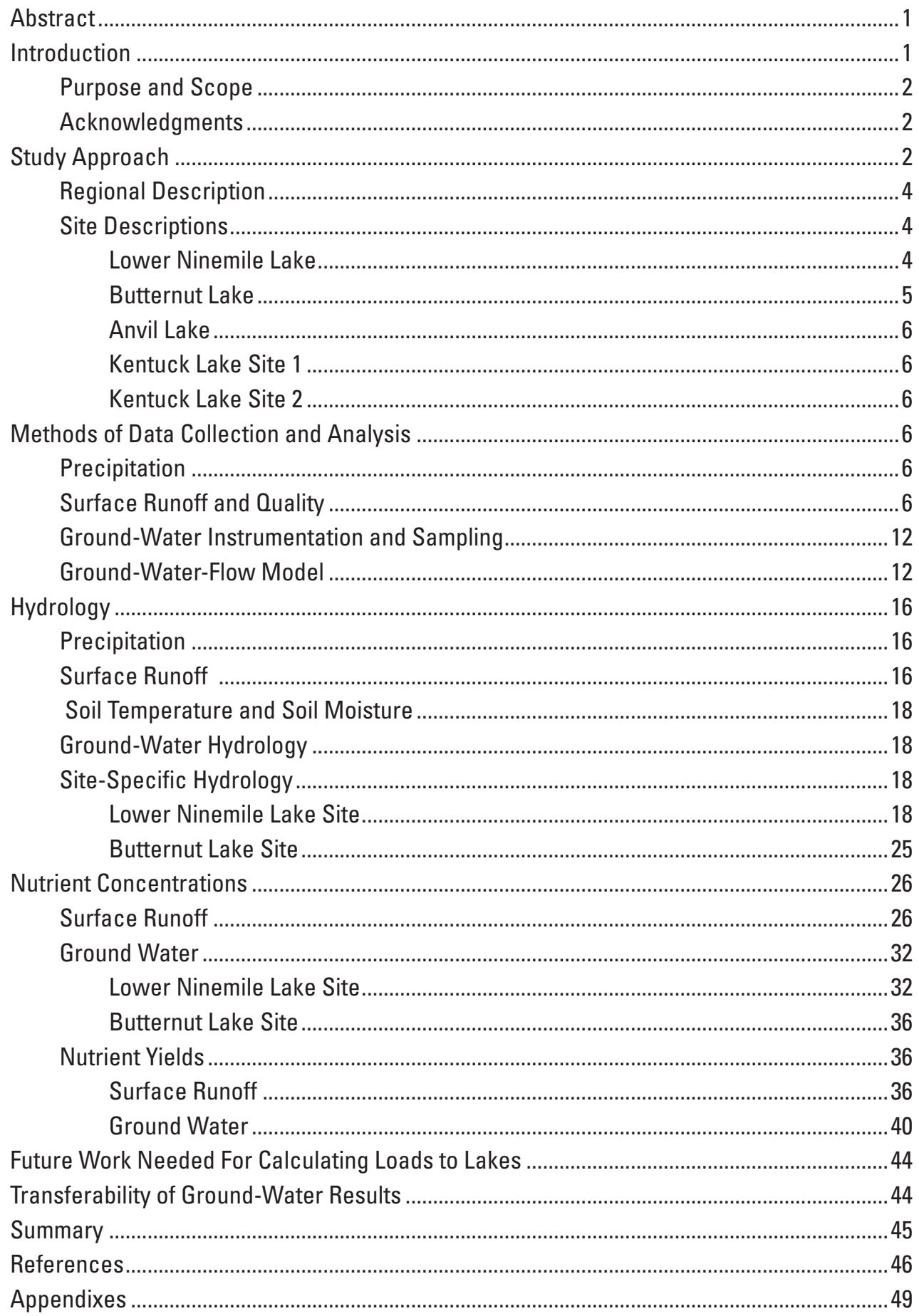




\section{Figures}

1-6. Maps showing:

1. Location of study area and data-collection sites.............................................. 3

2. Lower Ninemile Lake data-collection site..................................................... 5

3. Butternut Lake data-collection site ................................................................

4. Anvil Lake data-collection site .................................................................. 8

5. Kentuck Lake data-collection site 1 ..........................................................

6. Kentuck Lake data-collection site 2 …..................................................... 10

7. Schematic of automatic surface-runoff sampler............................................ 13

8. Map showing location targets and analytic elements used in the ground-water flow model

9-12. Graphs showing:

9. Lower Ninemile lawn and woods sites soil temperatures at 2 inches and 12 inches below ground surface

10. Butternut Lake lawn and woods sites soil temperatures at 2 inches and 12 inches below ground surface.

11. Lower Ninemile Lake lawn and woods sites soil moisture at 2 inches and 12 inches below ground surface.

12. Butternut Lake lawn and woods sites soil moisture at 2 inches and 12 inches below ground surface.

13. Maps showing:

13a.Simulated water table and head residuals for modeled area.

13b.Lake and tributary capture areas obtained from ground-water-flow model

14. Graph showing Lower Ninemile Lake levels, January 1, 1999 to March 1, 2002

15-16. Maps showing:

15. Water-table maps of Lower Ninemile Lake site showing the interconnectedness of the shallow aquifer and lake for three time periods.

16. Ground-water contour maps of Butternut Lake site for two time periods, northern Wisconsin

17-28. Graphs showing:

17. Vertical gradients at the Butternut Lake site P5 well nest 29

18. Concentrations of selected constituents for all samples collected by lawn and woods samplers

19. Phosphorus concentrations in the shallow ground-water system of the Lower Ninemile Lake site.

20. Nitrogen concentrations from the shallow ground-water system of the Lower Ninemile Lake site.

21a.Dissolved inorganic phosphorus concentrations in the shallow and deep ground-water systems of the Lower Ninemile Lake site

21b.Phosphorus concentrations from the shallow and deep ground-water systems of the Lower Ninemile Lake site.

22a.Nitrate plus nitrite concentrations from the shallow and deep ground-water systems of the Lower Ninemile Lake site.

22b.Ammonia concentrations from the shallow and deep ground-water systems of the Lower Ninemile Lake site.. 
23. Phosphorus concentrations from the shallow ground-water system of the Butternut Lake site.

24. Nitrogen concentrations from the shallow ground-water system of the Butternut Lake site.

25a.Dissolved inorganic phosphorus data concentrations the shallow and deep ground-water systems of the Butternut Lake site.

25b.Total phosphorus concentrations from the shallow and deep ground-water systems of the Butternut Lake site

26a.Nitrate plus nitrite concentrations from the shallow and deep ground-water systems of the Butternut Lake site

26b.Ammonia concentrations from the shallow and deep ground-water systems of the Butternet Lake site

27. Nutrient yields of surface runoff for lawn and wooded catchments. 41

28. Nitrate plus nitrite, ammonia, and Kjeldahl nitrogen annual yield at lawn and woods catchments

29. Dissolved and total phosphorus annual yield at lawn and woods catchments.

30. Comparison of surface-runoff and ground-water yields at the Lower Ninemile Lake site.

\section{Tables}

1. Type of data collected at each study site in northern Wisconsin ............................. 4

2. Catchment characteristics for data-collection sites, northern Wisconsin

3. Type and method of data collection at each site in northern Wisconsin................. 11

4. Results of quality-control samples for the five automatic samplers used in this study

5. Ground-water flow-model weights, measured values, simulated results for water-level and stream-flow targets

6. Precipitation at four data-collection sites for water years 2000 and 2001, northern Wisconsin

7. Summary statistics for surface runoff, runoff coefficients, and number of events at data-collection sites, northern Wisconsin

8. Estimated ground-water recharge from Lower Ninemile surface catchments, northern Wisconsin.

9. Summary of nutrient concentrations in surface-runoff samples collected at the lawn and woods catchments, northern Wisconsin

10. Composited values for nutrient concentrations, and number of samples collected at the lawn and woods runoff samplers at all properties for all storms, northern Wisconsin...

11. Comparison of runoff concentrations from other studies and data collected in this study of northern Wisconsin

12. Summary statistics for annual nutrient yields in runoff from the lawn and woods catchments, northern Wisconsin

13. Comparison of nutrient yields from previous studies throughout the country and from this study in northern Wisconsin. 


\section{Appendixes}

1. Soil core descriptions for selected wells in Vilas, Oneida, and Forest Counties, Wis.

2. Water chemistry data collected at lawn and wooded catchments, northern Wisconsin, October 1999-September 2001

3. Water chemistry data at the Butternut Lake site, and Lower Ninemile Lake site, northern Wisconsin; prior to snowmelt, early summer, and late summer.....

4. Constituent loads and yields at lawn and wooded catchments, northern Wisconsin, October 1999-September 2001. 


\section{Conversion Factors, Vertical Datum, and Abbreviated Units of Measurement}

\begin{tabular}{lcl}
\hline Multiply & By & To obtain \\
inch (in.) & 25.4 & millimeter $(\mathrm{mm})$ \\
foot $(\mathrm{ft})$ & 0.3048 & meter $(\mathrm{m})$ \\
mile (mi) & 1.609 & kilometer $(\mathrm{km})$ \\
acre & 0.4047 & hectare $($ ha $)$ \\
square mile $\left(\mathrm{mi}^{2}\right)$ & 2.590 & square kilometer $\left(\mathrm{km}^{2}\right)$ \\
square foot $\left(\mathrm{ft}^{2}\right)$ & 0.09294 & square meter $\left(\mathrm{m}^{2}\right)$ \\
cubic foot $\left(\mathrm{ft}^{3}\right)$ & 0.02832 & cubic meter $\left(\mathrm{m}^{3}\right)$ \\
gallon $(\mathrm{gal})$ & 3.785 & liter $(\mathrm{L})$ \\
cubic foot per second $(\mathrm{ft} / \mathrm{s})$ & 0.02832 & cubic meter per second $\left(\mathrm{m}^{3} / \mathrm{s}\right)$ \\
pounds per acre $(\mathrm{lb} / \mathrm{acre})$ & 112.1 & kilogram $(\mathrm{kg})$ \\
\hline
\end{tabular}

Temperature in degrees Fahrenheit $\left({ }^{\circ} \mathrm{F}\right)$ may be converted to degrees Celsius $\left({ }^{\circ} \mathrm{C}\right)$ as follows:

$$
{ }^{\circ} \mathrm{C}=\left({ }^{\circ} \mathrm{F}-32\right) / 1.8
$$

Elevation, as used in this report, refers to distance above mean sea level.

Vertical coordinate information is referenced to the North American Vertical Datum of 1988 (NAVD 88).

Abbreviated units of measurement used in this report: Physical measurements and chemical concentrations and water temperature are given in metric units.

The stratigraphic nomenclature used in this report is that of the Wisconsin Geological and Natural History Survey and does not necessarily follow that of the U.S. Geological Survey.

Water year: In the U.S. Geological Survey reports dealing with surface-water supply, the 12 -month period, October 1 through September 30. The water year is designated by the calendar year in which it ends and which includes 9 of the 12 months. Thus the year ending September 30, 2001 is called the "2001 water year". 


\title{
Hydrology, Nutrient Concentrations, and Nutrient Yields in Nearshore Areas of Four Lakes in Northern Wisconsin, 1999-2001
}

\author{
By David J. Graczyk', Randall J. Hunt' ${ }^{1}$, Steven R. Greb² ${ }^{2}$ Cheryl A. Buchwald', and James T. Krohelski ${ }^{1}$
}

\section{Abstract}

The effects of shoreline development on water quality and nutrient yields in nearshore areas of four lakes in northern Wisconsin were investigated from October 1999 through September 2001. The study measured surface runoff and ground-water flows from paired developed (sites containing lawn, rooftops, sidewalks, and driveways) and undeveloped (mature and immature woods) catchments adjacent to four lakes in northern Wisconsin. Water samples from surface runoff and ground water were collected and analyzed for nutrients. Coupled with water volumes, loads and subsequent yields of selected constituents were computed for developed and undeveloped catchments.

The median runoff from lawn surfaces ranged from 0.0019 to 0.059 inch over the catchment area. Median surface runoff estimates from the wooded catchments were an order of magnitude less than those from the lawn catchments. The increased water volumes from the lawn catchments resulted in greater nutrient loads and subsequent annual nutrient yields from the developed sites.

Soil temperature and soil moisture were measured at two sites with mixed lawn and wooded areas. At both of these sites, the area covered with a lawn commonly was warmer than the wooded area. No consistent differences in soil moisture were found.

A ground-water model was constructed to simulate the local flow systems at two of the paired catchments. Model simulations showed that much of the ground water delivered to the lake originated from distant areas that did not contribute runoff directly to the lake.

Surface runoff and ground-water nutrient concentrations from the lawn and wooded catchments did not have apparent patterns. Some of the median concentrations from lawns were significantly different (at the 0.05 significance level) from those at wooded catchments.
Water wells and piezometers were sampled for chemical analyses three times during the study period. Variability in the shallow ground-water chemistry over time in the lawn samples was larger than samples from the wooded areas and upgradient wells.

Median nutrient yields in surface runoff from lawns always were greater than those from the wooded catchments. Runoff volumes were the most important factor in determining whether lawns or wooded catchments contribute more nutrients to the lake.

The ground-water system had appreciable nutrient concentrations, and are likely an important pathway for nutrient transport to the lake. The nitrate plus nitrite nitrogen and total phosphorus yields to the ground-water system from a lawn catchment were approximately 3 to 4 times greater than those from the wooded catchment. There was no difference in the yields of dissolved inorganic phosphorus to the ground-water system from the lawn and wooded catchments.

Study results demonstrate that choosing the appropriate landscape position for locating lawns in sloped areas (specifically, slopes that do not terminate at the lake or areas with intervening flat or buffer zones between lawn and lake) can help reduce the adverse effect of lawns on the shallow ground water and, ultimately, the lake. Additional information would be needed to extrapolate these results to a large drainage area of a lake.

\section{Introduction}

The shoreline of a lake is the interface between terrestrial and aquatic ecosystems. Protection of this riparian area is important for a variety of reasons including wildlife habitat, water quality, and scenic views. Waterfront devel- 
opment has been rapid in northern Wisconsin in recent years. For example, lakes 500 to 1,000 acres in size have 9 times the number of homes on them today as they did in the 1960s (Wisconsin Department of Natural Resources, written commun., 1996). In addition, because of the premium price placed on lakeshore frontage, shoreline areas once thought undevelopable because of steep slopes, excessive wetness, or small area are now being built upon. Small seasonal cottages, no longer the norm for lakeshore dwellings, are being replaced by larger permanent homes.

A primary tool used in the protection of shoreland areas is shoreland-zoning laws. Wisconsin Administrative Code NR115 covers current shoreland zoning standards in the State of Wisconsin (Wisconsin Department of Natural Resources, 2000). The four major aspects of NR115 include control of development density, creation of vegetative buffers on public waterways, minimization of water-resource disturbances, and protection of wetlands. In addition to the State's NR115 code, counties may have additional shoreline-zoning requirements.

Previous studies have estimated the sediment and nutrient loadings from lake watersheds but few studies have determined the processes and pathways by which these constituents are delivered to a lake at a site scale. For example, few if any studies have determined the effectiveness of buffers or vegetation cutting restrictions on reducing chemical and sediment loads.

As development activities near lakes have increased, the movement of detrimental chemical constituents to lakes and the effects of these constituents on lakes have become important issues nationally, as well as in Wisconsin. In order to determine the effects of these constituents, surface-runoff and ground-water inputs to lakes and chemical loads they transport from small riparian catchments must be quantified. The U.S. Geological Survey, in cooperation with the Wisconsin Department of Natural Resources, conducted a study during 1999-2001 to determine surface-runoff and ground-water inputs to four lakes in northern Wisconsin.

\section{Purpose and Scope}

This report summarizes concentration data for nutrients, primarily nitrogen and phosphorus species, collected from 4 small riparian catchments draining to 4 lakes in northern Wisconsin (fig. 1). In addition, the concentration data were coupled with surface runoff and ground-water flows to compute loads and yields of nutrients in 4 catchments. The data-collection period was from November 1999 through September 2001.

\section{Acknowledgments}

The authors acknowledge the assistance of Truman (Gus) and Betty Gussick, Dolf and Carol Pfefferkorn, Harry Weart, Robert and Carlene Scott, Gerhard and Hilde Becker, and Candace Purdy. These property owners graciously allowed us to install equipment and monitor surface- and ground-water flow from their property and intrude on their privacy for 2 years. Without their assistance, patience, and unlimited access to their property, we could not have collected the data to complete this study. We also are grateful for the assistance of Sandy Gillum. Sandy's tireless effort in initially finding data-collection sites, for measuring ground-water levels, and collecting surface-water samples was invaluable to the successful completion of the study.

\section{Study Approach}

The effects of shoreline development on water and nutrient loading to lakes were assessed by means of a paired approach. The comparison focused on four lakes, three in Vilas County and one in Forest County in northern Wisconsin (fig 1). The study approach was (1) measure surface runoff and ground-water flows from developed catchments (sites containing lawn, rooftops, sidewalks, and driveways) and undeveloped catchments (mature and immature woods), (2) collect surface runoff and groundwater samples from the developed and undeveloped areas of each site for nutrient analyses, (3) couple water volumes and concentrations to determine loads and yields, and (4) compare and contrast concentrations, loads, and yields from developed and undeveloped land.

The study approach required a range of data-collection techniques. In order to conceptualize the distribution of flow to the ground-water and surface-water systems, measurements of soil temperature were made to assess times suitable for infiltration and indicate the qualitative evapotranspiration rate. Soil-moisture profiles were collected to assess the interception of infiltrating water and the antecedent conditions for the sites. Finally, a largescale $\left(\sim 185 \mathrm{mi}^{2}\right)$ ground-water-flow model was used to put the local sites into a regional framework and to constrain estimates of water recharged to the ground-water system.

A reconnaissance was done before the study began to determine whether surface runoff and ground-water-flow data could be collected at each site. Data collected from mini piezometers installed in the littoral zone helped establish two types of sites - sites where ground water flowed 

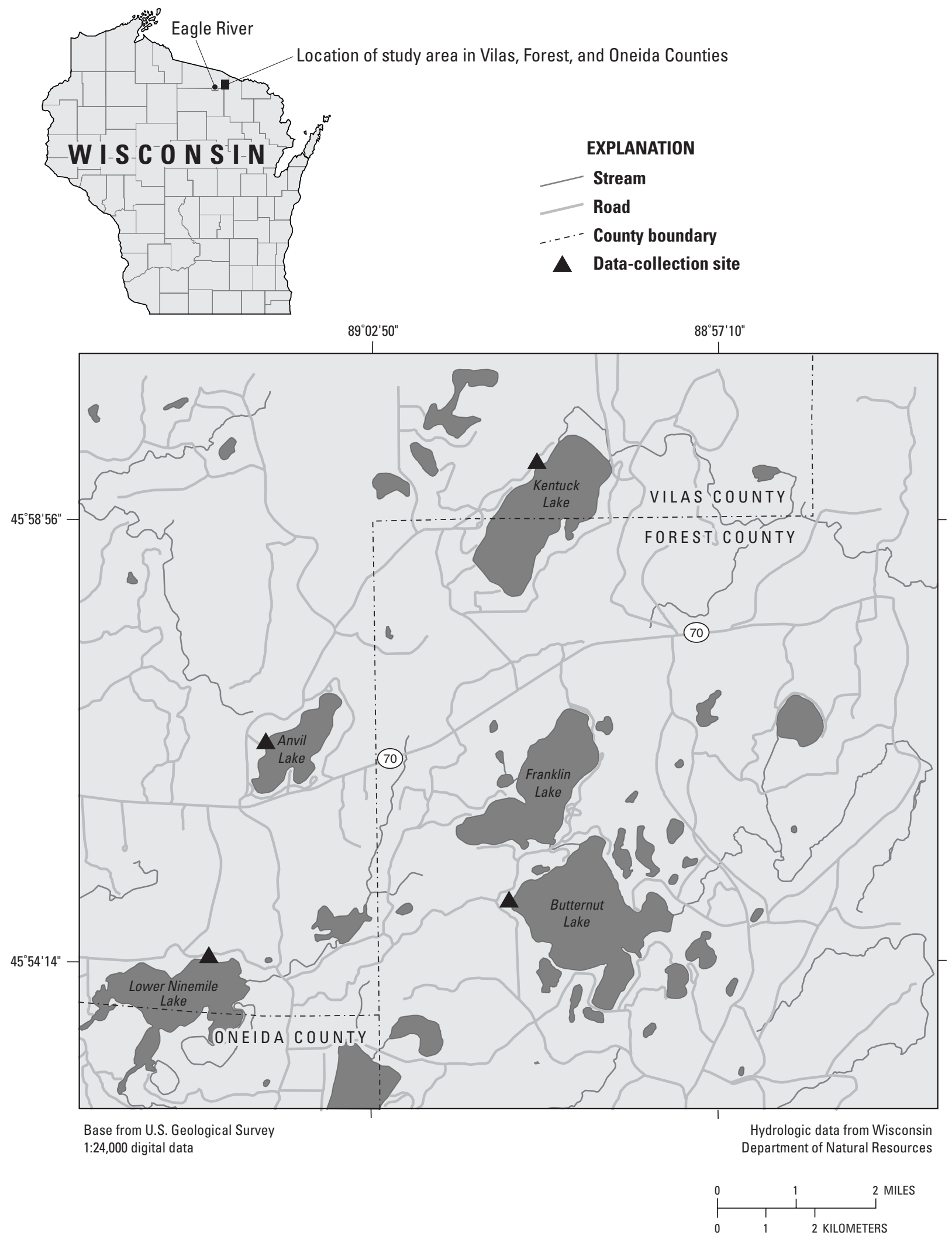

Figure 1. Location of study area and data-collection sites, northern Wisconsin. 
to the lake and sites where ground water flowed from the lake to the local ground-water system. Sites where ground water flowed to the lake were instrumented with both ground-water and surface runoff monitors. If the groundwater flow was away from the lake to the local groundwater system, then only surface runoff was monitored. The sites and type of data collected at each site can be found in table 1.

Table 1. Type of data collected at each study site in northern Wisconsin

[--, no equipment $]$

\begin{tabular}{lcccc}
\hline & \multicolumn{2}{c}{ Surface-water data } & \multicolumn{2}{c}{ Ground-water data } \\
\hline Lake & Lawn & Woods & Lawn & Woods \\
Lower Ninemile & $\mathrm{X}$ & $\mathrm{X}$ & $\mathrm{X}$ & $\mathrm{X}$ \\
Butternut & $\mathrm{X}$ & $\mathrm{X}$ & $\mathrm{X}$ & $\mathrm{X}$ \\
Kentuck site 1 & $\mathrm{X}$ & -- & $\mathrm{X}$ & -- \\
Kentuck site 2 & -- & $\mathrm{X}$ & -- & -- \\
Anvil & $\mathrm{X}$ & $\mathrm{X}$ & -- & -- \\
\hline
\end{tabular}

A paired approach was used - that is, areas of developed land (lawns and impervious areas) and wooded areas (minimally disturbed land) were monitored. At three of the lakes, Lower Ninemile, Butternut, and Anvil, these paired catchments were adjacent to each other on the same property. The two catchments at Kentuck Lake were considered paired even though they are at sites approximately $0.5 \mathrm{mi}$ from each other. In order to determine variability within sites, multiple undeveloped and developed catchments were monitored within each site.

\section{Regional Description}

Knowledge of the regional hydrogeological system is needed in order to understand how the catchments interacted with the lakes. Geologic data used during this study consisted of interpretive geologic maps and reports presented by Attig (1985) for Vilas County and by Simpkins and others (1987) for Forest County. These sources are excerpted briefly here. Glacial deposits of the Langlade Lobe are present throughout southeastern Vilas, northeastern Oneida, and northwestern Forest Counties. These deposits, known as the Nashville Member of the Copper Falls Formation, range in thickness from about $40 \mathrm{ft}$ to over $250 \mathrm{ft}$ and generally overlie mafic metavolcanic rock (Attig, 1985). The Nashville Member is composed of till (mixture of gravel and loamy sand), generally deposited subglacially, and sand and outwash (mixture of sand and gravel) deposited by meltwater.
Glacial lakes in northern Wisconsin typically were formed when an ice block broke off the retreating glacier, was surrounded or buried by outwash, and left a depression in the landscape, known as a kettle; it is when the ice melted and filled this kettle that a kettle lake was formed. Kettle lakes are typified by a high variability of deposits found in the vicinity of the lakes. This variability is a result of the depositional environments ranging from flowing meltwater streams (sand and gravel) to more calm backwater areas where fine-grained sediment (silts and clay) accumulated. Kentuck, Anvil, and Butternut Lakes probably were formed by melted ice blocks that protruded above aggrading sand and gravel. As the ice melted, finegrained material became interbedded with the coarser sand and gravel. Simpkins and others (1987) describe surficial deposits in the vicinity of these lakes as sand and gravel in areas of hummocky topography. Meltwater streams deposited poorly to moderately well sorted sand and gravel on ice that eventually melted to form the hummocky topography.

The fourth study lake, Lower Ninemile, is substantially different from the kettle lakes; it can be described as a flowage lake because the origin of Lower Ninemile Lake is a manmade dam that backs up water. Therefore, interbedded fine-grained material typical of kettle lakes would not be expected in the vicinity of a flowage lake (John Attig, Wisconsin Geological and Natural History Survey, written commun., 2002). Attig (1985) describes the deposits in the vicinity of Lower Ninemile Lake as collapsed stream sediment. Peat deposits (partially decomposed organic matter) are present in small areas that are low-lying and poorly drained in the Lower Ninemile Lake vicinity.

\section{Site Descriptions}

The data-collection network, drainage area, and site layout are shown in figures 2-6. A detailed description of each site follows. A description of soil cores from these sites can be found in appendix 1. Monitoring equipment was installed such that the direct effect of runoff from impervious surface was minimized. The results represent runoff from riparian turf-covered areas without significant effect from impervious-surface runoff.

\section{Lower Ninemile Lake}

Two adjacent catchments, one draining a developed part and one draining an undeveloped part of the property were monitored (fig. 2). The lawn catchment drained 
$975 \mathrm{ft}^{2}(0.0224$ acre $)$, with a slope of 14 percent. The wooded catchment drained $720 \mathrm{ft}^{2}$ (0.0165 acre), with a slope of 15 percent (table 2). The turf density was fairly thin, and the soil at depth was sandy with well-sorted gravel (appendix 1). The wooded catchment consisted of conifers and deciduous hardwoods with an understory of immature deciduous hardwoods. There were a few shrubs with a mat of decaying conifer needles and other decaying organic matter for ground cover. The soils in the woods consisted of a 3-ft mantle of silt over sand.

\section{Butternut Lake}

A lawn catchment of $440 \mathrm{ft}^{2}(0.0101$ acre $)$ was monitored along with two adjacent wooded sites: upper woods with a catchment size of $420 \mathrm{ft}^{2}(0.0096$ acre $)$ and lower woods with a catchment size of $130 \mathrm{ft}^{2}(0.0030$ acre $)$ (fig. 3 and table 2). The slopes of the lawn, upper woods, and lower woods were 17,16 , and 16 percent, respectively (table 2). The turf density was fairly thick; underneath the turf was a sandy soil mixed with gravel, and a lacustrine clay at depth (appendix 1). The wooded areas (upper and

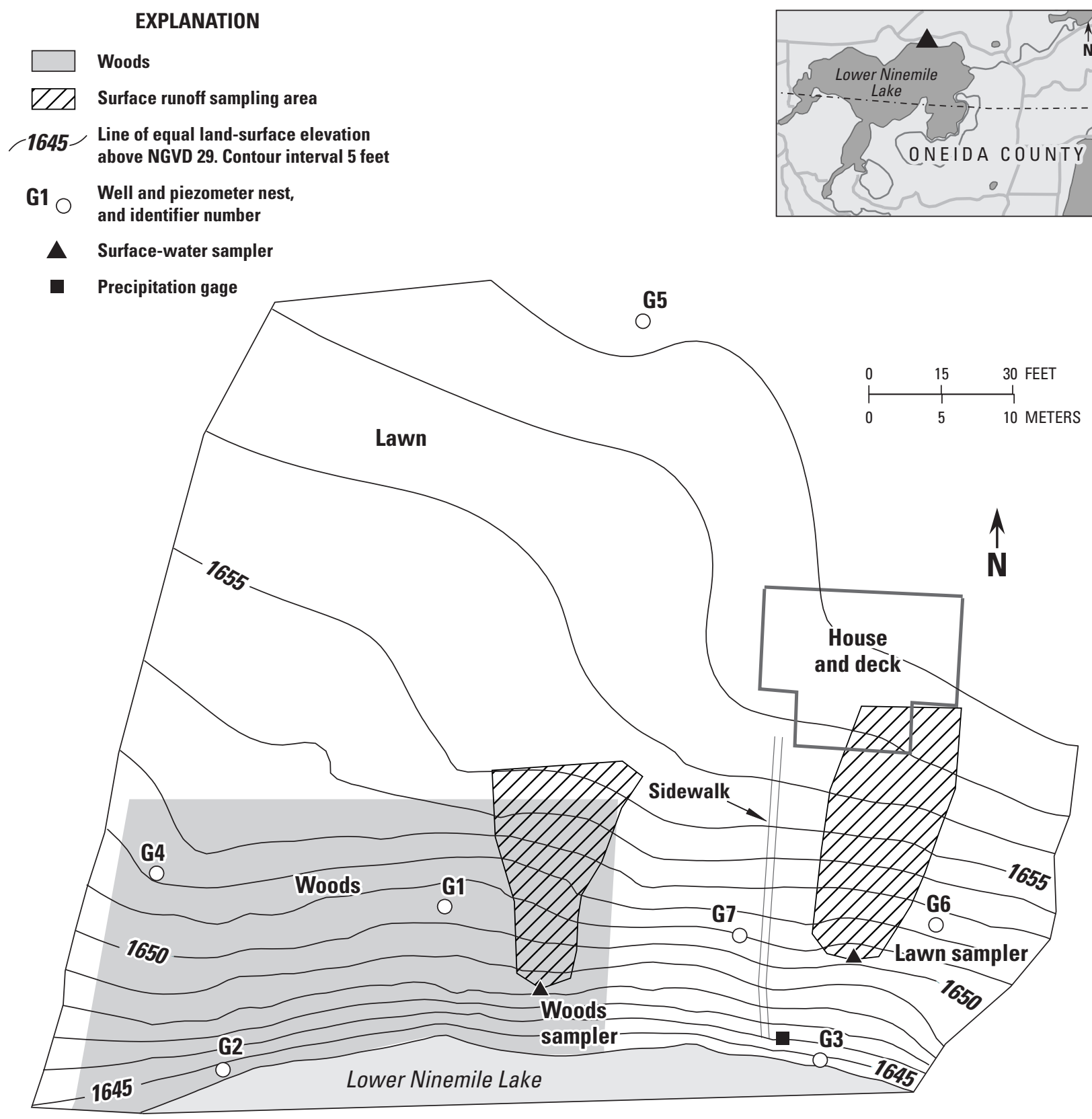

Figure 2. Lower Ninemile Lake data-collection site, northern Wisconsin. 
lower) consisted of mature deciduous hardwoods and conifers. The ground cover was leaf litter and other decaying organic matter. The soil consisted of sand and gravel.

\section{Anvil Lake}

The lawn catchment drained the smallest area of the study, $85 \mathrm{ft}^{2}(0.0020$ acre) and the slope was 14 percent (fig. 4 and table 2). Three wooded catchments drained areas of $400 \mathrm{ft}^{2}$ (0.0092 acre), $385 \mathrm{ft}^{2}$ (0.0088 acre), and $365 \mathrm{ft}^{2}(0.0084$ acre for woods 1 , woods 2 , and woods 4 , respectively (fig. 4 and table 2). The turf density was fairly thick, and grass was interspersed with moss. The wooded areas consisted mostly of mature deciduous hardwoods with a subcanopy of deciduous hardwoods. The ground cover was mostly upland sedges, leaf litter, and other decaying organic matter over soils of silt, sand, and gravel.

\section{Kentuck Lake Site 1}

The lawn catchment drained an area of $1,080 \mathrm{ft}^{2}$ ( 0.0248 acre) with a gentle slope of 5 percent (fig. 5 and table 2). This catchment was the largest of all the lawn catchments monitored, but it had the lowest slope (table 2). The turf density was fairly thick. The soils appeared to be lacustrine deposits and fairly tight. Water from snowmelt and heavy precipitation ponded on the lawn and infiltrated slowly, and it evaporated or ran off for longer periods compared with the other lawn sites. Although groundwater levels were measures during the study, ground-water

Table 2. Catchment characteristics for data-collection sites, northern Wisconsin

[ft², square feet]

\begin{tabular}{lrrc}
\hline \multicolumn{1}{c}{ Site } & \multicolumn{2}{c}{ Drainage area } & Slope \\
\cline { 2 - 3 } & \multicolumn{1}{c}{ (ft') $^{2}$} & (acre) & (percent) \\
\hline Lower Ninemile Lake, lawn & 975 & 0.0224 & 14 \\
Lower Ninemile Lake, woods & 720 & .0165 & 15 \\
Butternut Lake, lawn & 440 & .0101 & 17 \\
Butternut Lake, upper woods & 420 & .0096 & 16 \\
Butternut Lake, lower woods & 130 & .0030 & 16 \\
Anvil Lake, lawn & 85 & .0020 & 14 \\
Anvil Lake, woods 1 & 400 & .0092 & 24 \\
Anvil Lake, woods 2 & 385 & .0088 & 23 \\
Anvil Lake, woods 4 & 365 & .0084 & 22 \\
Kentuck Lake site 1, lawn & 1,080 & .0248 & 5 \\
Kentuck Lake site 2, woods & 108 & .0025 & 10 \\
\hline
\end{tabular}

sampling and analysis were not done because of the low infiltration rate of surface runoff.

\section{Kentuck Lake Site 2}

The wooded catchment was paired with the site 1 lawn catchment on Kentuck Lake, which is approximately $0.5 \mathrm{mi}$ north of site 2 . The site 2 wooded catchment was $108 \mathrm{ft}^{2}(0.0025$ acre $)$, and the slope was 10 percent (fig. 6 and table 2). The site 2 wooded catchment was the smallest wooded catchment monitored. The canopy at site 2 consisted of mature deciduous hardwoods and some conifers. The understory was mostly immature deciduous hardwoods with a ground cover of leaf litter and moss that was several inches thick.

\section{Methods of Data Collection and Analysis}

Precipitation, surface runoff and water quality, ground-water flow and water quality, ground-water levels, soil temperature, and moisture data were collected from developed and undeveloped catchments. Each data type is described in the following paragraphs.

\section{Precipitation}

Tipping-bucket rain gages were installed at four of the paired sites (figs. 2, 3, 4, and 6). The rainfall record at Kentuck Lake site 2 was used for the rainfall record at site 1 . The precipitation during the nonfrozen portion of the year (March 15 to November 15) was measured at 15-minute intervals and summed for the day. Precipitation during the winter was estimated from National Oceanic and Atmospheric Administration (NOAA) weather records collected at Eagle River, Wis., approximately $10 \mathrm{mi}$ west of the data-collection sites (fig. 1).

\section{Surface Runoff and Quality}

The quantity and quality of surface runoff was monitored by means of two types of collectors. The nonautomated samplers used for quantity and quality are described by Waschbush and others (1999). The sampler consisted of two 5-ft lengths of a 0.5 in diameter polyvinyl chloride (PVC) well pipe with slots cut into and along its length. The pipes then were placed side by side in a shallow depression, perpendicular to the slope, so that surface 


\section{EXPLANATION}

Woods

Surface runoff sampling area

Line of equal land-surface elevation above sea level. Hachures indicate depression. Contour interval 1 foot

P1 Well and piezometer nest, and identifier number

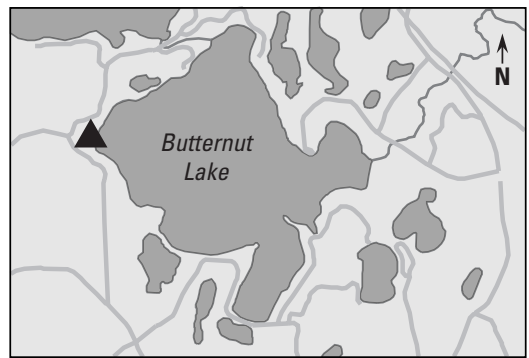

- Surface-water sampler

- Precipitation gage

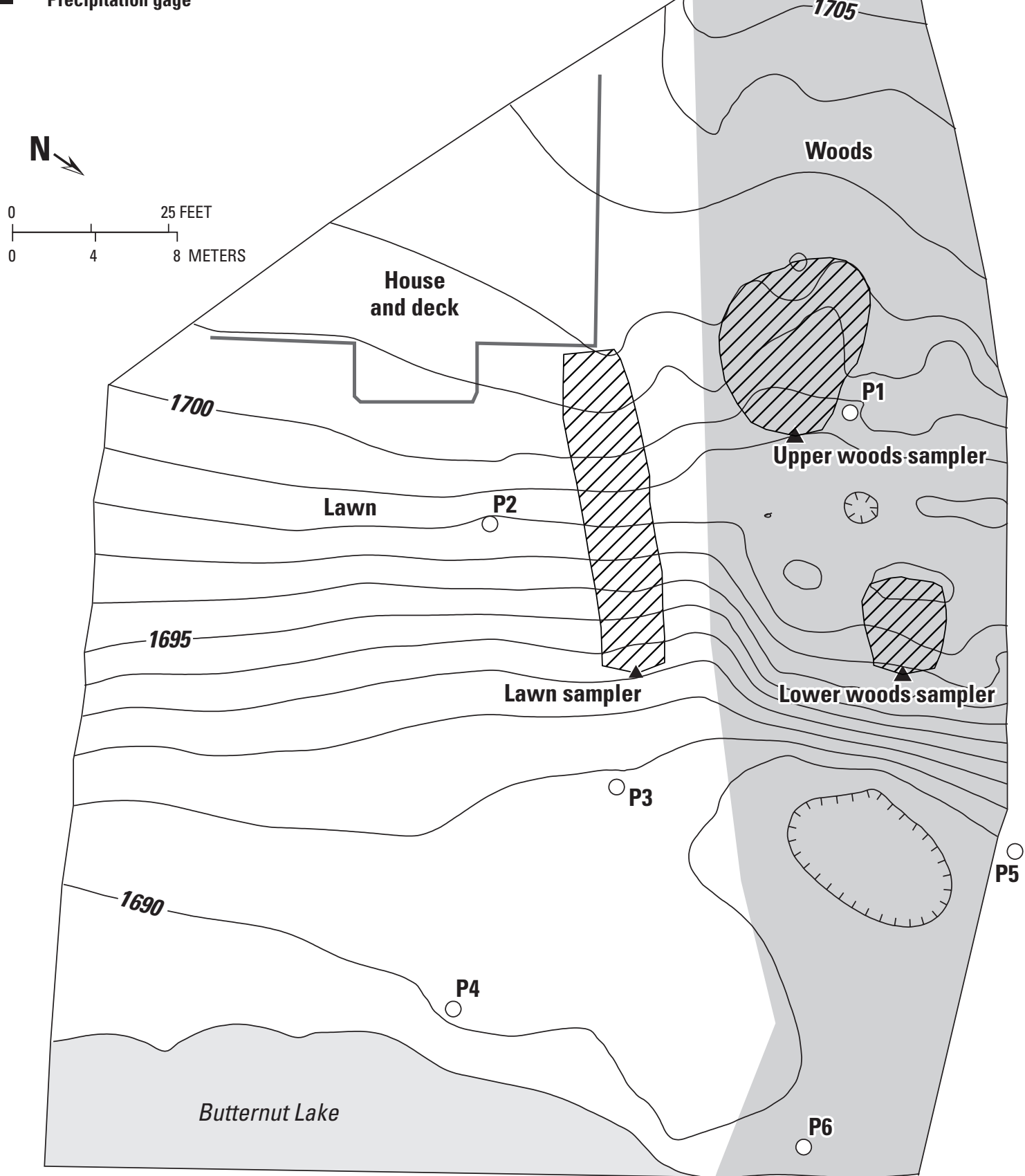

Figure 3. Butternut Lake data-collection site, northern Wisconsin. 


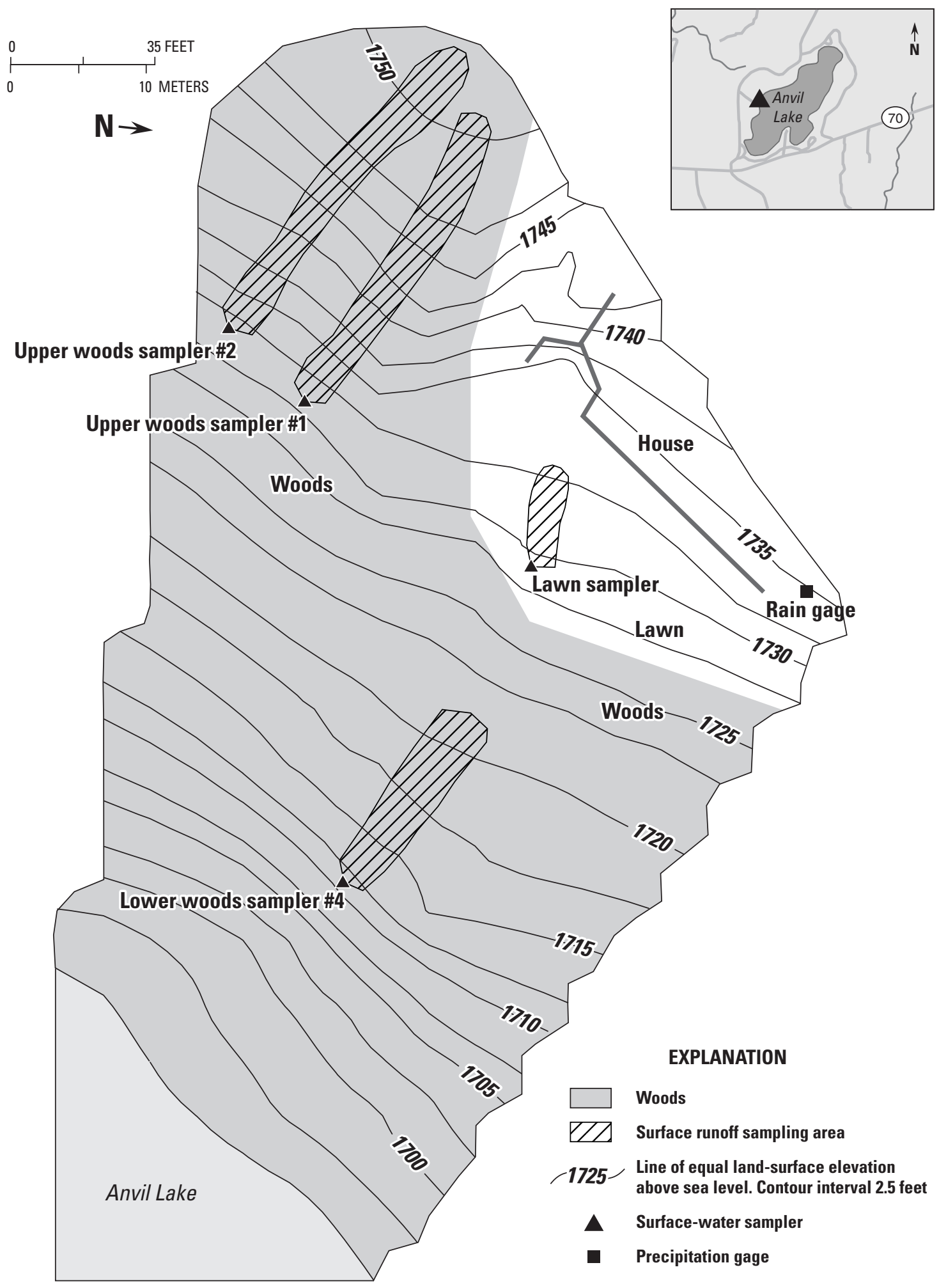

Figure 4. Anvil Lake data-collection site, northern Wisconsin. 


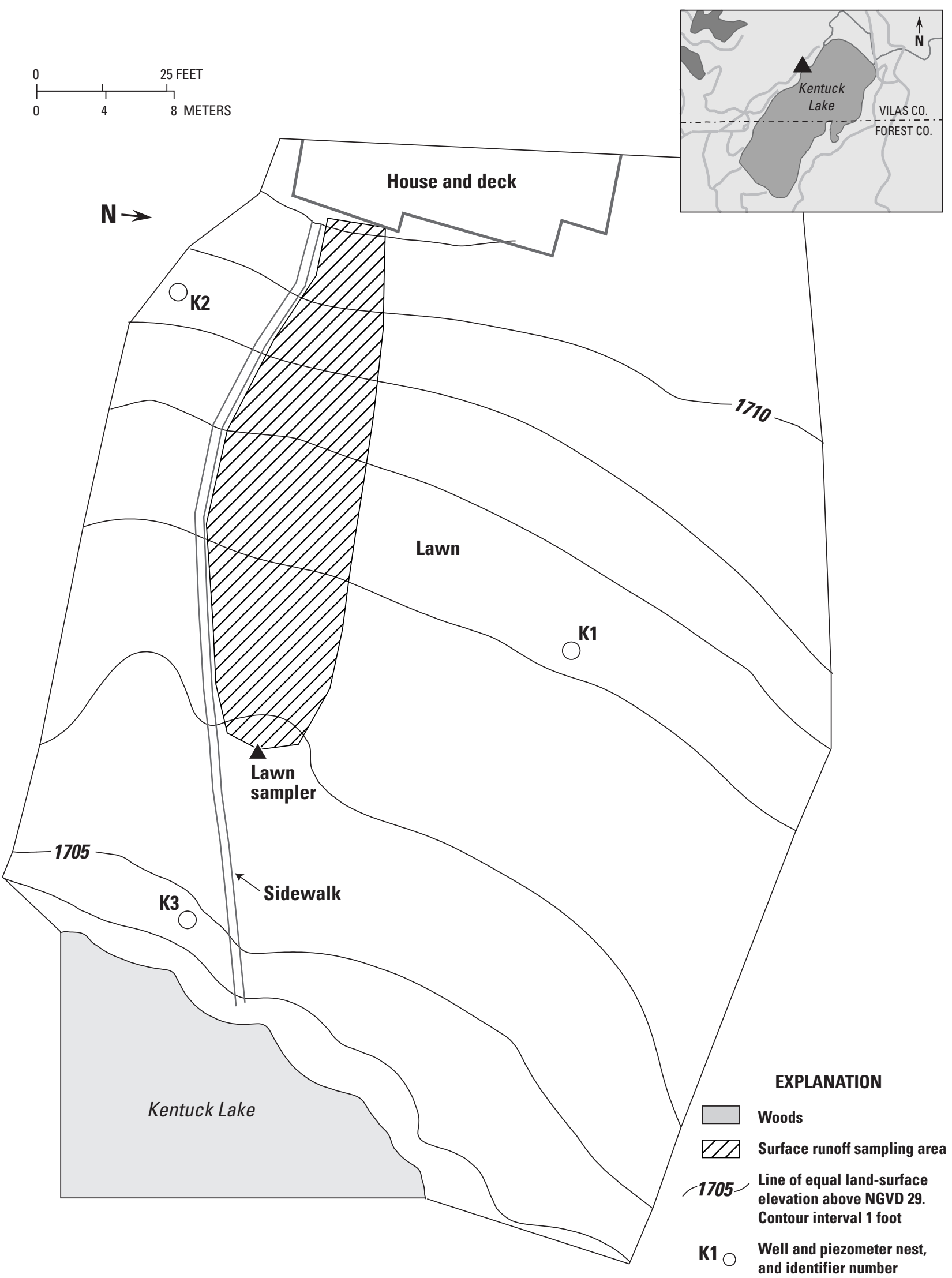

- Surface-water sampler

Figure 5. Kentuck Lake data-collection site 1, northern Wisconsin. 


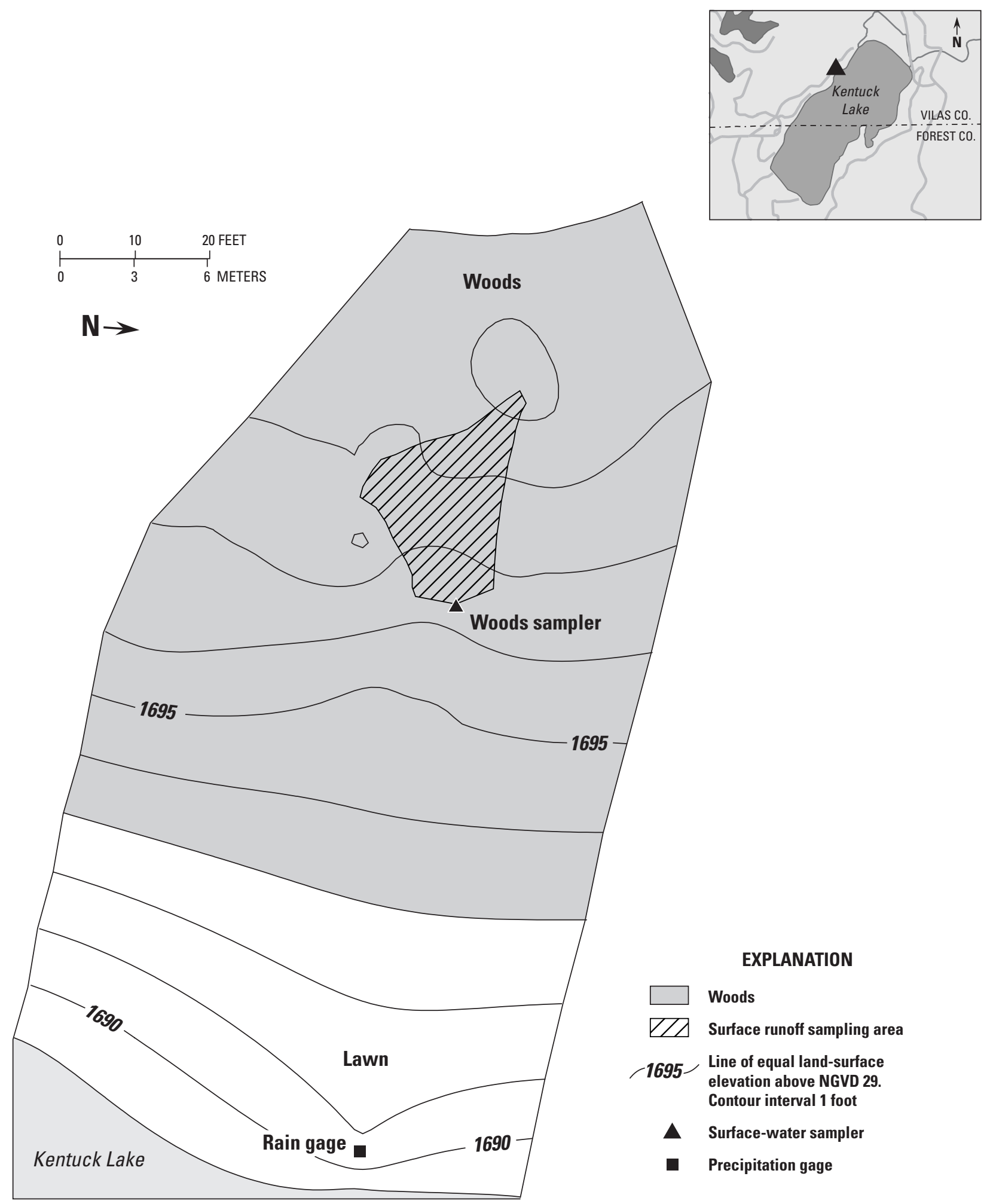

Figure 6. Kentuck Lake data-collection site 2, nothern Wisconsin. 
runoff was intercepted and could drain into a 1-gal glass bottle that was buried at the intersection of the two pipes. This type of collector was installed at six catchments (table 3). The sampler was checked weekly, plus after rain and snowmelt events, by a local observer. The surfacerunoff quantity was estimated by determining the volume of water collected. On several occasions the sample bottle was full and, therefore, may have overfilled. The volume for these storms was considered a minimum. Samples were processed using a 10-port plastic sample splitter to obtain the volume needed for analysis by the Wisconsin State Laboratory of Hygiene (WSLOH). If there was not enough water (less than $100 \mathrm{~mL}$ ) to process and analyze a sample, the water was discarded and the bottle was rinsed with distilled water and then replaced.

Automatic monitors were installed at five catchments (table 3). The monitor consisted of an approximately 10-ft-long plastic barrier driven into the ground with approximately 0.5 to $1 \mathrm{in}$. of the barrier remaining above the ground (fig. 7). As surface runoff flowed to the barrier, the barrier deflected the runoff to a drain in the center of the barrier. The runoff drained into a large-volume tipping bucket. The tipping bucket was calibrated before deployment in the field so that the volume of water could be determined with each tip. The tipping bucket drained into a 5-gal collector buried in the ground below the barrier. Water was pumped from this collector to another 5-gal collector. The total number of tips was recorded. Some water was diverted into a sample collector and used for water-quality analysis. A local observer checked the sampler weekly, and more frequently after rainfall events. Samples were processed through a cone splitter until the required volume of water remained for analysis of the selected constituents.

Unfiltered samples were used for determination of ammonia, nitrate plus nitrite, Kjeldahl nitrogen, and total phosphorus concentrations. Samples to be analyzed for dissolved phosphorus were filtered in the field (0.45-micron cellulose nitrate filter). All samples were analyzed by the WSLOH using standard methods (Wisconsin State Laboratory of Hygiene, 1992).

Quality-control samples were collected from the automatic surface-water samplers to ensure that a minor design problem was not biasing the data. The design of the automatic sampler system may have resulted in some water remaining in the pump bucket. This remaining water could not be completely pumped out during or after the rainfall event when the sampler was serviced, but it would be pumped out during the next event, or if there was sufficient time between events, would evaporate and could leave a residue. This residue could redissolve during the next event. Five quality-control samples were collected at Lower Ninemile lawn and Kentuck Lake site 2 woods sampler, four were collected from the Butternut and Kentuck Lake site 1 lawn samplers, and three were collected at the Lower Ninemile woods sampler (fig. 1).

The quality-control sample was collected by processing 1,000 to $3,000 \mathrm{~mL}$ of distilled water through the sampling system. The median concentration (in milligrams per liter) at each site can be found in table 4 . The concentrations may appear high, but the effect of the residue carryover was expected to be the largest for small events and negligible for larger events. Because small events were small contributors to load calculations, residue effects were not considered further in this study.

Table 3. Type and method of data collection at each site in northern Wisconsin

$[--$, no equipment $]$

\begin{tabular}{|c|c|c|c|c|c|c|c|}
\hline \multirow[b]{2}{*}{ Site } & \multirow[b]{2}{*}{ Precipitation } & \multicolumn{2}{|c|}{ Surface runoff } & \multicolumn{2}{|c|}{ Surface-water quality } & \multirow{2}{*}{$\begin{array}{c}\text { Ground-water } \\
\text { quantity }\end{array}$} & \multirow{2}{*}{$\begin{array}{c}\text { Ground-water } \\
\text { quality }\end{array}$} \\
\hline & & Nonautomatic & Automatic & Nonautomatic & Automatic & & \\
\hline Lower Nine Mile Lake, lawn & $\mathrm{X}$ & -- & $\mathrm{X}$ & -- & $\mathrm{X}$ & $\mathrm{X}$ & $\mathrm{X}$ \\
\hline Lower Nine Mile Lake, woods & -- & -- & $\mathrm{X}$ & -- & $\mathrm{X}$ & $\mathrm{X}$ & $X$ \\
\hline Butternut Lake, lawn & $X$ & -- & $\mathrm{X}$ & -- & $X$ & $\mathrm{X}$ & $\mathrm{X}$ \\
\hline Butternut Lake, woods & -- & $X$ & -- & $\mathrm{X}$ & -- & $X$ & $X$ \\
\hline Butternut Lake, woods & -- & $X$ & -- & $X$ & -- & $\mathrm{X}$ & $X$ \\
\hline Anvil Lake, lawn & $\mathrm{X}$ & $\mathrm{X}$ & -- & $\mathrm{X}$ & -- & -- & -- \\
\hline Anvil Lake, woods 1 & -- & $\mathrm{X}$ & -- & $\mathrm{X}$ & -- & -- & -- \\
\hline Anvil Lake, woods 2 & -- & $\mathrm{X}$ & -- & $\mathrm{X}$ & -- & -- & -- \\
\hline Anvil Lake, woods 4 & -- & $\mathrm{X}$ & -- & $\mathrm{X}$ & -- & -- & -- \\
\hline Kentuck Lake site 1 , lawn & -- & -- & $X$ & -- & $\mathrm{X}$ & -- & -- \\
\hline Kentuck Lake site 2, woods & $X$ & -- & $\mathrm{X}$ & -- & $\mathrm{X}$ & -- & -- \\
\hline
\end{tabular}


Table 4. Results of quality-control samples for the five automatic samplers used in this study

[All values are median concentration in milligrams per liter]

\begin{tabular}{lcccccc}
\hline \multicolumn{1}{c}{ Site } & $\begin{array}{c}\text { Number of } \\
\text { samples }\end{array}$ & $\begin{array}{c}\text { Ammonia } \\
\text { nitrogen }\end{array}$ & $\begin{array}{c}\text { Nitrate plus } \\
\text { nitrite }\end{array}$ & $\begin{array}{c}\text { Kjeldahl } \\
\text { nitrogen }\end{array}$ & $\begin{array}{c}\text { Dissolved } \\
\text { phosphorus }\end{array}$ & $\begin{array}{c}\text { Total } \\
\text { phosphorus }\end{array}$ \\
\hline Lower Nine Mile Lake, lawn & 5 & 0.12 & 0.11 & 0.65 & 0.05 & 0.16 \\
Lower Nine Mile Lake, woods & 3 & .10 & .39 & 2.8 & .063 & .14 \\
Butternut Lake, lawn & 4 & .26 & .54 & 1.1 & .06 & .12 \\
Kentuck Lake site 1, lawn & 4 & .15 & .84 & 1.4 & .10 & .21 \\
Kentuck Lake site 2, woods & 5 & .67 & 1.2 & 2.2 & .22 & .49 \\
\hline
\end{tabular}

\section{Ground-Water Instrumentation and Sampling}

A series of water-table wells (long screens intersecting the uppermost ground water) and piezometers (short screen wells installed below the water table) were installed at Lower Ninemile Lake, Butternut Lake, and Kentuck Lake site 1 by means of hydraulic push equipment (figs. 2, 3, and 5). The water-table wells (given the designation "A") consisted of a 1-in.-diameter PVC well riser and a 5-ft PVC well screen. The screen was placed such that the midpoint was near the water level measured during installation. The piezometers consisted of a 3/8-in. well riser with a 6-in. screen for intermediate ("B") and deep ("C") piezometers placed near water-table wells and approximately $10-15 \mathrm{ft}$ and $20-25 \mathrm{ft}$ below land surface, respectively. Water levels in the wells and piezometers were measured by hand approximately biweekly except for winter periods, when the measurements were approximately monthly. The water-table wells also were instrumented with pressure transducers and capacitance probes that collected water-level measurements on regular intervals. Pressure transducers have been reported to have nonsystematic errors when used for long-term, water-level monitoring (Rosenberry, 1990); therefore, water-level data were removed when there were large discrepancies (greater than $0.1 \mathrm{ft}$ ) between the transducer measurement and the hand-measured water level.

The Lower Ninemile and Butternut site wells were sampled in February, June, and August 2001. The February sampling included water-table wells (A wells) and deeper piezometers ( $\mathrm{B}$ and $\mathrm{C}$ piezometers; maximum depth of $25 \mathrm{ft}$ ) in order to assess the base-line concentrations of the shallow and deep systems. The June sampling also included shallow and deep locations to assess the change in the constituent concentrations at the water table and the effect of changes in the shallow ground-water system on the deeper ground-water system. The August sampling included only the shallow water-table wells. The water-table wells were evacuated completely or pumped to remove at least three well volumes with a peristaltic pump before sampling. Unfiltered samples were used for field measurements of specific conductance, temperature, $\mathrm{Eh}$, and $\mathrm{pH}$, and laboratory measurements of alkalinity. Filtered samples (0.45-micron cellulose nitrate filter) were collected for determination of ammonia, nitrate plus nitrite, Kjeldahl nitrogen, dissolved inorganic phosphorus (DIP), and total phosphorus concentrations. Samples were analyzed by the WSLOH using standard methods (Wisconsin State Laboratory of Hygiene, 1992).

Soil temperatures were measured at the lawn and woods catchments at the Lower Ninemile Lake and Butternut Lake properties to assess when the surface was frozen (times of low ground-water recharge and high surface runoff). Soil-moisture measurements were collected to assess what were representative moisture levels in the wooded and developed catchments to understand the flow distribution and potential for evapotranspiration interception. Unsaturated zones at the catchments were instrumented with a thermocouple and soil-moisture probe. Data were collected hourly at 2 -in. and $1-\mathrm{ft}$ depths by means of stationary thermocouples and time-domain reflectometers. At the Lower Ninemile Lake site, the lawn and wooded catchments were instrumented on sloped areas of the landscape. At the Butternut Lake site, the woods catchment was instrumented on a slope, whereas the lawn was instrumented on a flat area adjacent to the base of the slope (near well P3 in fig. 3).

\section{Ground-Water-Flow Model}

An analytic element ground-water-flow model, using the computer program GFLOW (Haitjema, 1995), was developed to simulate the shallow ground-water system and its interaction with surface-water features. A complete description of analytic element modeling is beyond the scope of this report; a brief description taken from Hunt and others (2000) is given below. Strack (1989) and 
Haitjema (1995) provide detailed discussions of the analytic element method.

An infinite aquifer is assumed in analytic element modeling. To construct an analytic element model, features important to ground-water flow (for example, wells) and surface-water features are entered as mathematical elements. Each element is represented by an analytic solution. The effects of these individual solutions are superposed, or added together, to arrive at a solution for the groundwater-flow system. In the GFLOW model used here, the analytic elements are two-dimensional and are used to simulate only steady-state conditions (that is, water-levels do not vary with time). Comparisons of analytic element to finite-difference numerical model techniques have been discussed by others (Hunt and Krohelski, 1996; Hunt and others 1998, Haitjema and others, 2001).

The GFLOW model was calibrated by use of parameter-estimation techniques that have been applied to other ground-water-flow models in Wisconsin (Hunt and others, 2000; Hunt and Steuer, 2000; Kelson and others, 2002). Briefly, the primary benefit of a properly constructed
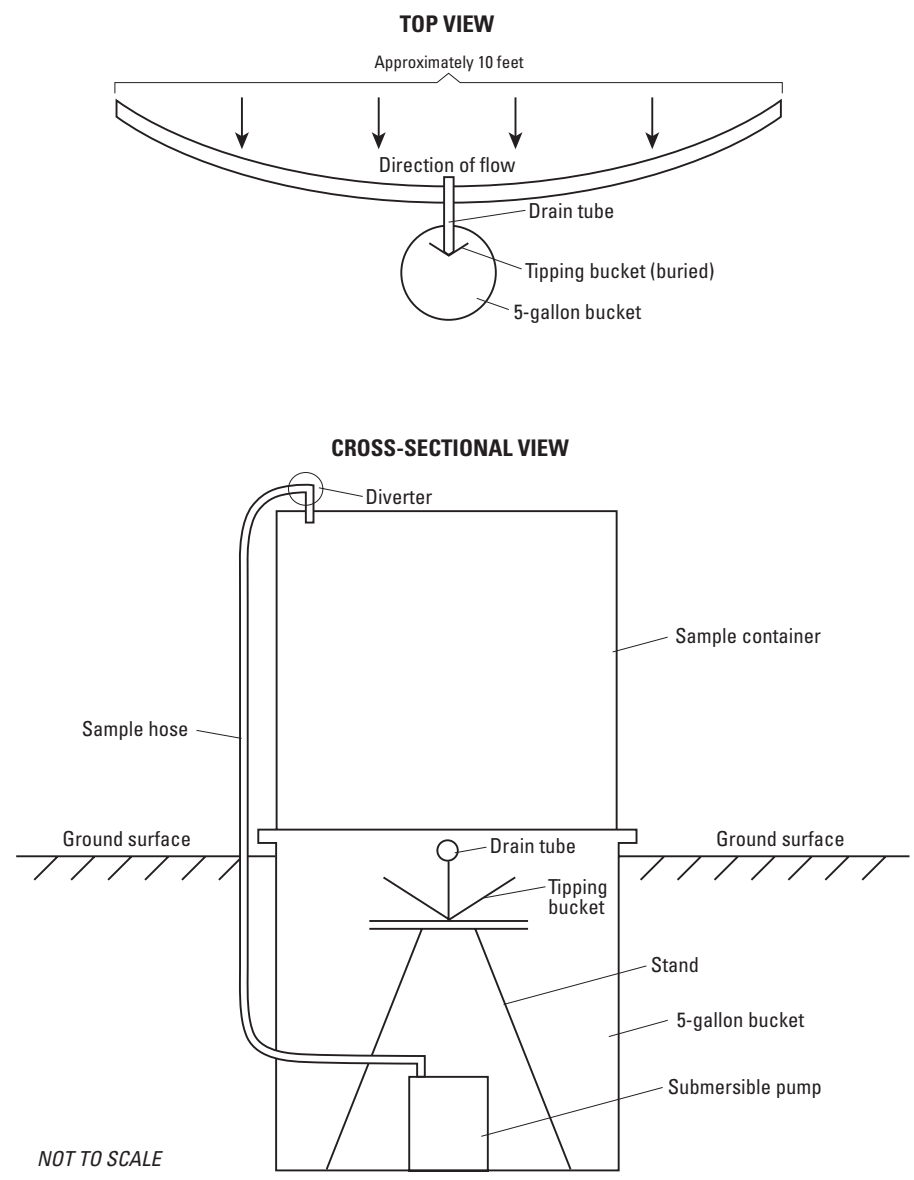

Figure 7. Schematic of automatic surface-runoff sampler used in this study. parameter-estimation model over typical trial-and-error calibration is the ability to automatically calculate parameter values that are a quantified best fit between simulated model output and observed data. In this study, the GFLOW model was coupled with the parameter estimation code UCODE (Poeter and Hill, 1998).

Initial model development included estimating the elevation of the base of the shallow aquifer, a global recharge rate, and a horizontal hydraulic conductivity. The base of the model approximates the bottom of the highconductivity unconsolidated sediments (about 1,550 ft above sea level). The global recharge rate and horizontal hydraulic conductivity were considered calibration parameters; thus, these parameters were varied during model calibration. Initially, recharge was set to $10.5 \mathrm{in} / \mathrm{yr}$ and horizontal hydraulic conductivity set to $28.4 \mathrm{ft} / \mathrm{d}$, based on previous modeling results in the area by Hunt and others (1998).

The ground-water-flow model consists of "far-field" and "near-field" elements. The location and elevation of far-field surface-water features were added to the model

(dark green lines in fig. 8) and are simulated with coarse linesinks (linear analytic elements used to simulate surface-water features) and little or no resistance between the surface-water features and the groundwater system. The purpose of simulating the far-field features is to explicitly define the regional groundwater-flow field around the primary area of interest, or "near-field." In this study, the near-field is the primary area of interest and encompasses Lower Ninemile and Butternut Lakes, as well as other nearby features that affect the hydrology of the lakes (blue and pink lines in fig. 8).

Streambed-sediment resistance in the near-field was set equal to 0.5 day. Resistance in analytic element modeling is calculated by dividing the streambedsediment thickness by the vertical hydraulic conductivity. For this model, the value of 0.5 day corresponds to a 1-ft sediment thickness and a vertical hydraulic conductivity of $2.0 \mathrm{ft} / \mathrm{d}$. The stream width was assigned according to stream order and ranged from 1 to $40 \mathrm{ft}$. Parameter sensitivity assessments within UCODE demonstrated that the model results are not sensitive to changes in stream or lake resistance when varied over reasonable ranges; therefore, the values for specific streams and lakes were fixed in all simulations.

Surface-water features were simulated with a range of sophistication. Streams in the far-field were not used for streamflow calibration; thus, streams simply were modeled as individual linesinks. 


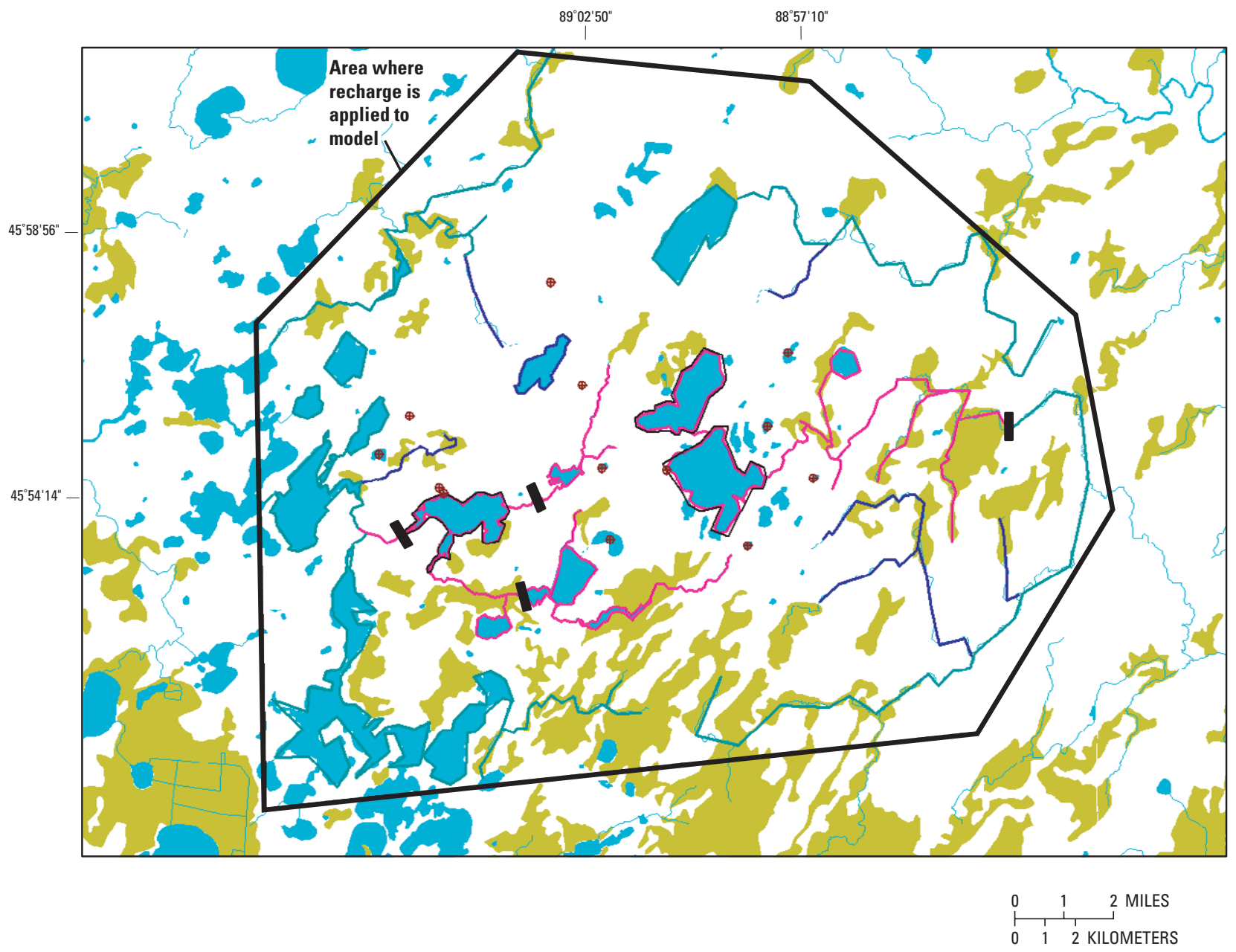

EXPLANATION

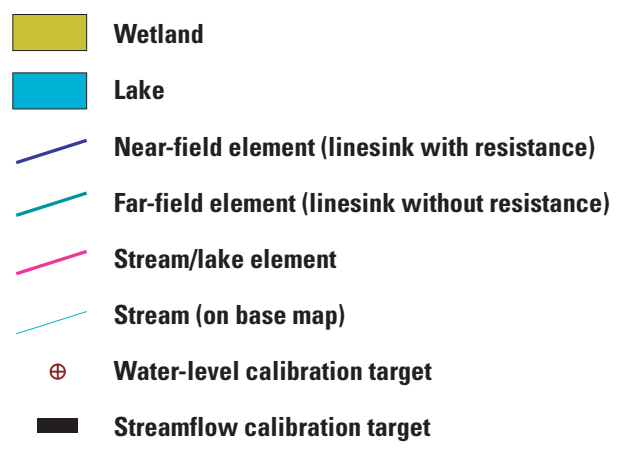

Figure 8. Location targets and analytic elements used in the ground-water-flow model, northern Wisconsin. 
Near-field streams were used for streamflow calibration and used a "stream element" (Mitchell-Bruker and Haitjema, 1996) that accounted for upstream gains and losses to base flow. Streams simulated using stream elements are shown as pink lines in figure 8. Lakes where simulation of lake stage was not desired were simulated as linesinks with resistance. Drainage lakes in the near-field were linked to the stream network by stream elements based on the methodology of Hunt and others (1998). Two of the study lakes (Lower Ninemile and Butternut Lakes) were simulated by means of a newly developed analytic lake element (Hunt and others, 2003). The lake element solves for lake stage on the basis of simulated surface-water inflows and estimated surface-water outflows from the lake. The value of resistance was set equal to 0.5 day for flowage lakes and 0.5 to 10 days for kettle lakes. Annual precipitation and evaporation over the lakes was set to 31.1 and $21.3 \mathrm{in} / \mathrm{yr}$, respectively, on the basis of long-term averages for models constructed in western Vilas County (Hunt and others, 1998).

The model was evaluated with measured data that included ground-water levels and streamflow (fig. 8). Data collected during this study and existing field data were used to evaluate the far-field areas of the model. Groundwater levels for six existing wells were obtained from well-construction reports (four wells) and levels measured as part of this study (two wells). In addition, calibration targets from area seepage lakes that were thought to represent the water table (seven lakes) also were used. Stages from the study lakes (Lower Ninemile and Butternut Lakes) were not used as calibration targets because surface-water outlets controlled their stage. Average conditions (the median flow, or Q50) from a historical streamflow-gaging station on the North Branch Pine River near Alvin (USGS station 04063640) were used as a calibration target. This target is important because it drains a large

Table 5. Ground-water flow-model weights, measured values, simulated results for water-level and streamflow targets for the analytic element model, northern Wisconsin

[Optimized recharge $=9.7$ inches per year; horizontal hydraulic conductivity $=18$ feet per day. STD, standard deviation (feet); CV, coefficient of variation (dimensionless)]

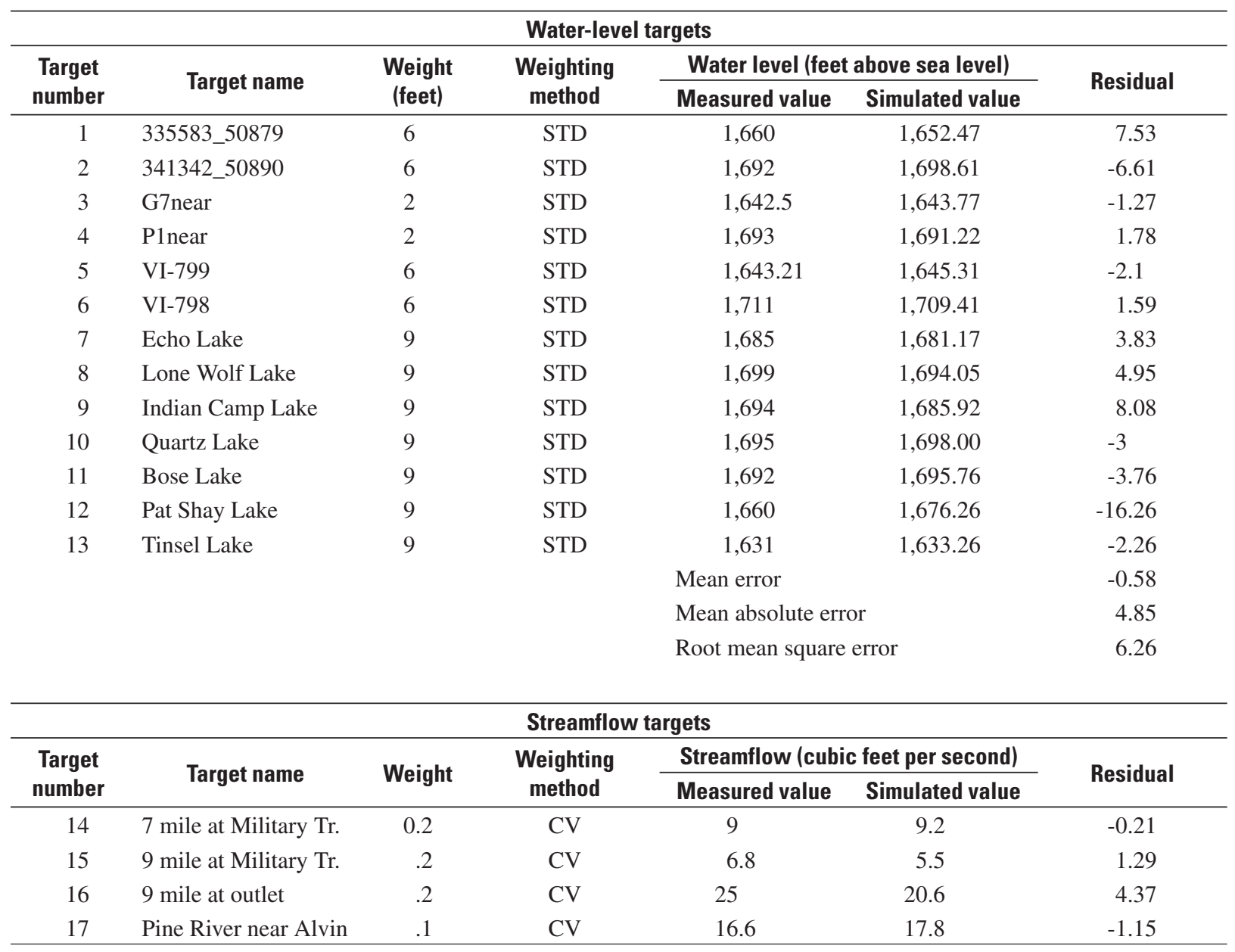


part of the study area and is considered representative of present conditions, although the gaging station ceased operation in 1967. Preliminary model results indicated that additional information regarding the distribution of streamflow in the site area was needed. Therefore, a synoptic survey (a spatially distributed set of measurements taken at approximately the same time) of flows was done on April 30, 2002. Sites in this survey included Sevenmile Creek at Military Trail, Lower Ninemile Creek at Military Trail, and the Lower Ninemile Lake outlet. Because this time period was not a time of median flows, the measured flows were adjusted to the daily median flow using the data from the nearest operating USGS gaging station (Popple River at Fence, USGS station 04063700; approximately 30 miles southeast of Ninemile Lake).

The parameter optimization requires the modeler to formalize the importance of the calibration targets by assigning weights to the observed values (table 5). These associated standard deviations for ground-water levels and lake stages ranged from 2 to $9 \mathrm{ft}$ (table 5). The Pine River gaging station base-flow target was assigned a coefficient of variation of 0.1 . The synoptic flow targets do not have flow-duration information and were given less weight in the optimization (coefficient of variation equal to 0.2 ).

\section{Hydrology}

\section{Precipitation}

Rainfall recorded at each site for water years 2000 and 2001 can be found in table 6 .

Table 6. Precipitation at four data-collection sites for water years 2000 and 2001, northern Wisconsin

[NOAA, National Oceanic and Atmospheric Administration]

\begin{tabular}{lcc}
\hline \multicolumn{1}{c}{ Site } & $\begin{array}{c}\text { Partial } \\
\text { water year } \\
\mathbf{2 0 0 0}^{\text {a }} \\
\text { (in.) }\end{array}$ & $\begin{array}{c}\text { Water year } \\
\mathbf{2 0 0 1} \\
\text { (in.) }\end{array}$ \\
\hline Lower Ninemile Lake rain gage & 27.99 & 27.25 \\
Butternut Lake rain gage & 31.13 & 28.53 \\
Kentuck Lake rain gage & 26.76 & 29.86 \\
Anvil Lake rain gage & 29.70 & 29.53 \\
Long-term NOAA average & $27.74^{\mathrm{b}}$ & 30.21 \\
\hline
\end{tabular}

${ }^{a}$ Data collection started November 15. Used NOAA rain gage from November 1 to November 15.

${ }^{\mathrm{b}} 11$-month average.
Precipitation in water year 2000 ranged from 26.76 in. to 31.13 in. and in water year 2001 precipitation ranged from 27.75 in. to 29.86 in. Precipitation at the study site bracketed the long-term normal precipitation of $27.74 \mathrm{in}$. for water year 2000 (11-month period) and was below the normal of 30.21 in. during water year 2001 (National Oceanic and Atmospheric Administration, 2000).

\section{Surface Runoff}

Surface runoff was collected at the study sites to compute loads and yields of constituents. The runoff, in inches, from each catchment and the calculated runoff coefficient (the ratio of surface runoff to total rainfall that produced that runoff) can be found in table 7. The median surface runoff from lawns ranged from 0.002 in. (Anvil Lake Site) to 0.059 in. (site 1 Kentuck Lake) (table 7). Although the slope of the Kentuck Lake site 1 catchment was the least steep of all the lawn catchments, it had the largest runoff coefficient. This high runoff coefficient likely was due to the lacustrine soil at Kentuck Lake site 1 being very fine grained with low permeability. Rainfall often pooled on the surface, infiltrated slowly, and ran off.

The sandier soil at the Lower Ninemile Lake lawn had a median runoff coefficient of 0.013 (table 7). The other two lawns at Butternut and Anvil Lakes were thicker than the Lower Ninemile Lake lawn and had lower runoff coefficients than the other sites (table 7). The largest median runoff coefficient was 0.06 for the lawn catchment at Kentuck Lake (table 7).

Results from the study sites can be compared to the coefficient base in the Source Loading and Management Model (SLAMM), which is used to generate runoff volume from urban runoff and contaminant source areas (Pitt and Voorhees, 1993). The SLAMM coefficient base has been developed using runoff monitoring data from a number of sites throughout Wisconsin. The median runoff coefficient for the clay soils at the Kentuck Lake site 1 is in the range used in SLAMM. Likewise, the runoff coefficients for the sites with more sandy soil (Lower Ninemile, Butternut, and Anvil) also are in the range of runoff coefficients used in SLAMM. In an ongoing study in Madison, Wis., a lawn similar to that at Lower Ninemile Lake had a median runoff coefficient of 0.014 (Todd Stuntebeck, U.S. Geological Survey, written commun., 2002), which is similar to the median runoff coefficient from this study. The other two lawns, one at Butternut Lake and the other at Anvil Lake, are thicker than those at the Lower Ninemile Lake site and had similar runoff coefficients to lawns being 


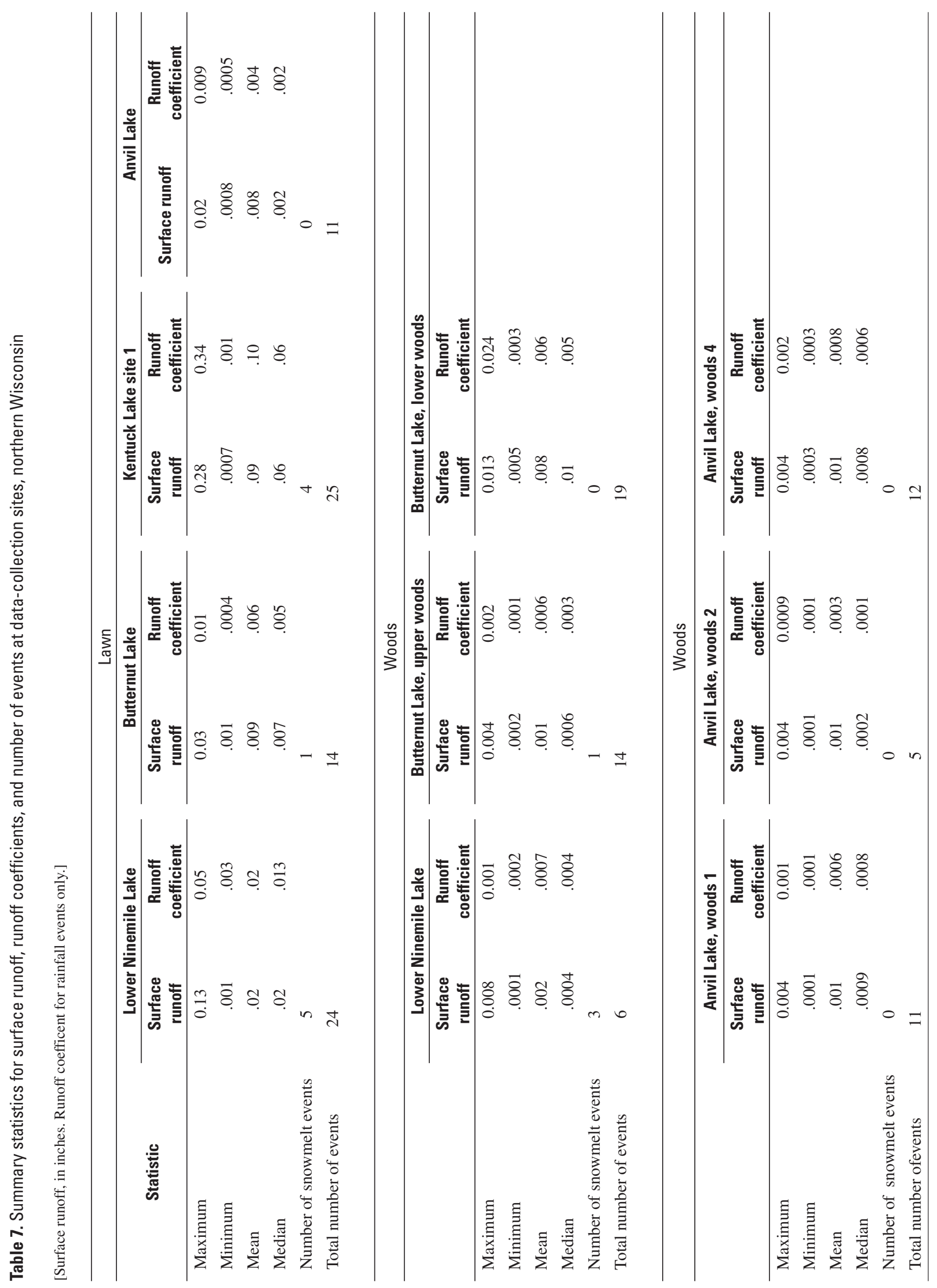


studied in Madison, Wis. (Todd Stuntebeck, U.S. Geological Survey, written commun., 2002).

Generally, the median surface-runoff estimates from the wooded catchments were an order of magnitude less than the median surface runoff from the lawn catchments. In one case (Kentuck Lake site 2), not a single runoff event occurred during the study. The lower runoff observed at the wooded catchments may be due to a number of factors: (1) the tree canopy likely intercepted a portion of the precipitation, (2) the thick organic-matter layer at the surface may have retarded runoff by absorbing the rainfall that fell on the wooded catchments, or (3) increased permeability in the upper soil due to bioturbation (for example, worm holes may have allowed most of the precipitation to infiltrate). Other investigators have determined that wooded catchment-runoff coefficients range from 0.05 to $0.025-$ much higher values than observed in this study (table 7).

\section{Soil Temperature and Soil Moisture}

At both the Lower Ninemile Lake and Butternut Lake sites, the lawn commonly was warmer than the woods during the growing season (figs. 9 and 10); the period that the ground was frozen, however, was similar at both types of catchments. Therefore, duration of frozen ground is not considered to be a controlling process on the volume of runoff generated at these sites. At the Lower Ninemile Lake site, the lawn consistently was drier than the woods, both at a depth of $2 \mathrm{in.} \mathrm{and} 12 \mathrm{in}$. (fig. 11), indicating less water infiltrated the soil in the lawn than in the woods. At the Butternut Lake site, the opposite relation was noted (fig. 12). This result is attributed to different locations in the topographic landscape. Whereas the Lower Ninemile Lake lawn and woods instrumentation were both on a slope, the Butternut Lake woods instrumentation was on a slope but the lawn instrumentation was on a flat area at the base of the slope. The enhanced runoff of water that, in turn, infiltrated the soil at the base of the slope would account for higher soil moistures. The associated evapotranspiration, however, appeared to be higher at Butternut Lake because of the higher temperature (fig. 10), the additional available shallow soil moisture (fig. 12 top panel), and the reduction in moisture difference between the 2-in. and 12-in. depth (fig. 12). Increased infiltration into the shallow soil at the base of the lawn slope may be evapotranspired before it could recharge to the groundwater system.

\section{Ground-Water Hydrology}

Simulated water-table and water-level residuals from the optimized model are shown in figure 13a. The optimized recharge (9.7 in/yr) and horizontal hydraulic conductivity $(18 \mathrm{ft} / \mathrm{d})$ were similar to those used in nearby areas (Hunt and others, 1998; Kelson and others, 2002). The differences between measured and simulated ground-water and lake levels were a mean of $0.6 \mathrm{ft}$, a mean absolute error of $4.8 \mathrm{ft}$, and a root mean square error of $6.3 \mathrm{ft}$ (table $5)$. The largest error in lake stage was noted in the simulation of Pat Shay Lake. Because this target is located on a steep hydrologic gradient, the simulated stage could have been improved by simulating the lateral extent of the lake. The large residual also may be a result of site-specific geologic features that may control the local ground-waterflow system but were not included in the regional model. Simulated flows also were reasonable in magnitude (all values are within 20 percent of measured value) at a given site (table 5) but also as distributed throughout the basin.

The ground-water-model results illustrate important concepts about flows to lakes in this area. First, water flows toward surface-water features from distant areas (on the order of miles); therefore, areas that constitute the ground-water-recharge areas (or zones) for lakes and tributaries are outside the immediate near-shore catchment. The model also can be used to calculate the capture zones (fig. 13b) of Lower Ninemile Lake and Butternut Lake. (The other study basins are not shown because they were not explicitly included in the modeling for this study.) These capture zones reflect all the areas that provide ground-water recharge to the lakes and the tributary systems to the lakes. Second, simulation results demonstrate that the zones that feed a lake system can be small or large and are a function of the larger surface-water system rather than the size of the lake. Moreover, the vulnerability of a lake to changes in the watershed will depend, in part, on the size of its capture zone. Finally, although the ground-water model can characterize the regional system, a smaller-scale view of the site hydrology is needed to interpret the local catchments monitored during this study.

\section{Site-Specific Hydrology}

\section{Lower Ninemile Lake Site}

Because the Lower Ninemile Lake site has characteristics of a flowage lake (a river that has been dammed), the geologic depositional history and associated near-lake sediments are simpler than ice-block (kettle) lakes in the 
2 INCHES BELOW GROUND SURFACE
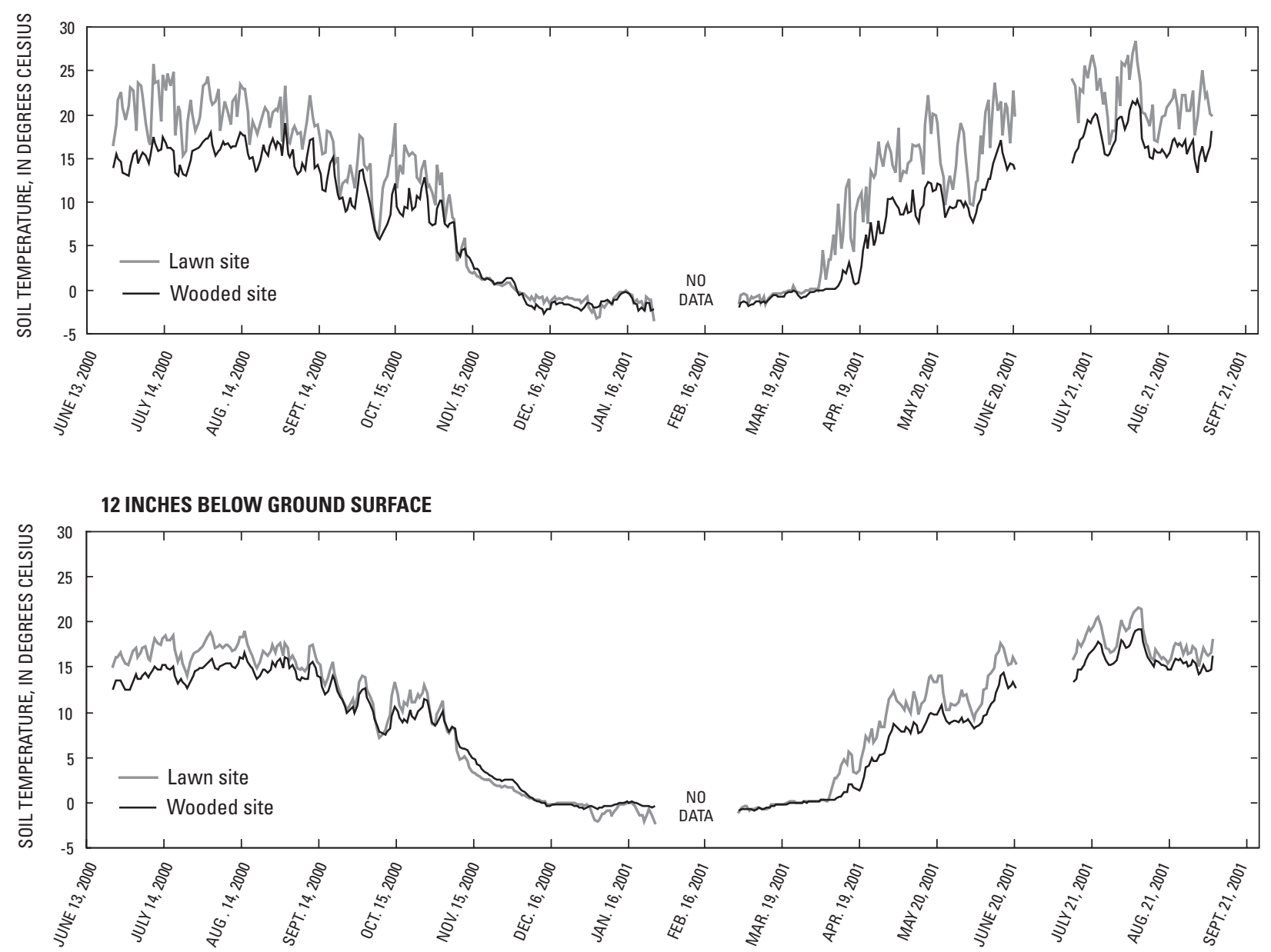

Figure 9. Soil temperatures at 2 inches and 12 inches below ground surface, Lower Ninemile Lake lawn and wooded catchments, northern Wisconsin. 
2 INCHES BELOW GROUND SURFACE
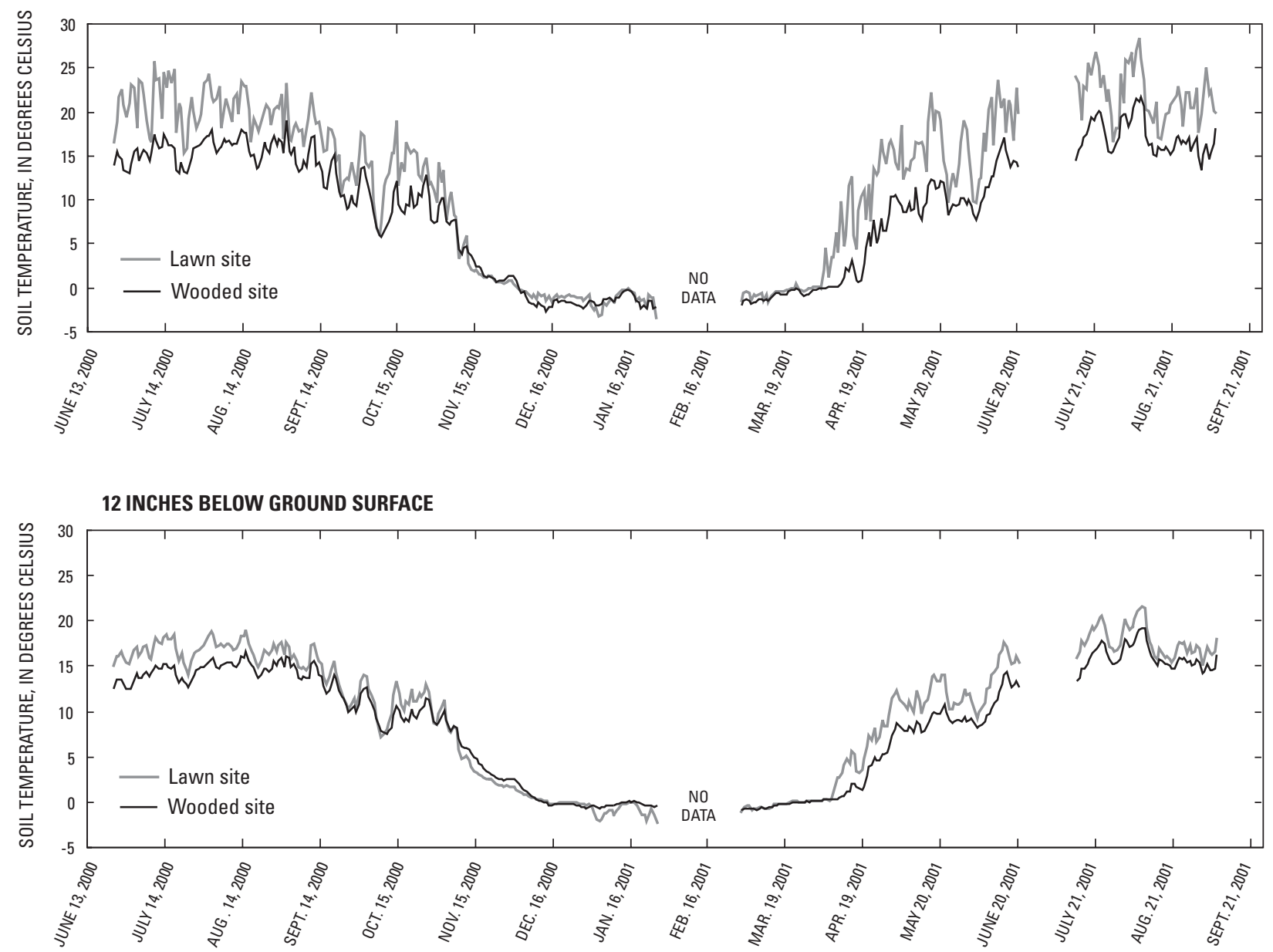

Figure 10. Soil temperatures at 2 inches and 12 inches below ground surface, Butternut Lake lawn and wooded catchments, northern Wisconsin. 
2 INCHES BELOW GROUND SURFACE
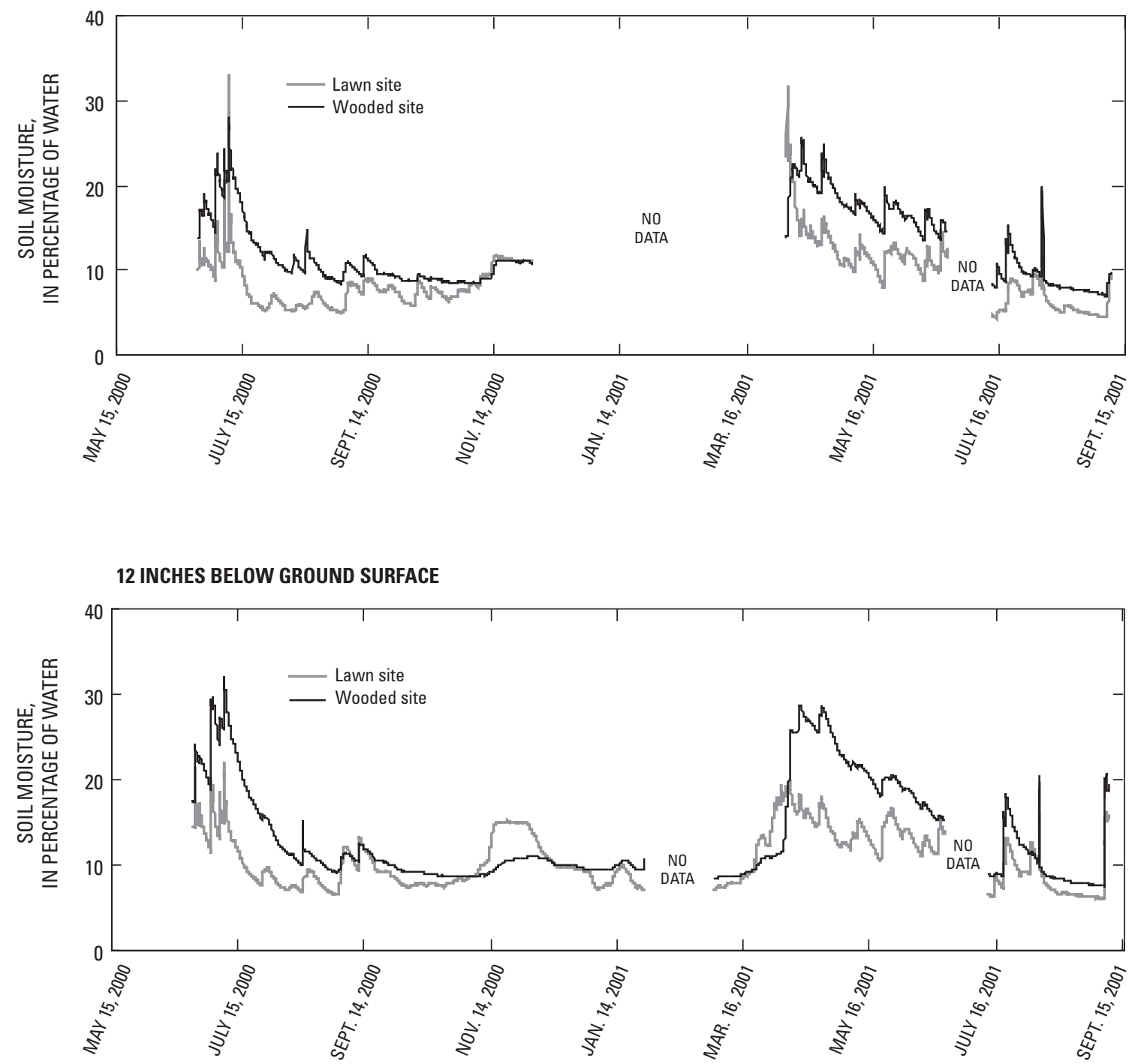

Figure 11. Soil moisture at 2 inches and 12 inches below ground surface, Lower Ninemile Lake lawn and wooded catchments, northern Wisconsin. 
2 INCHES BELOW GROUND SURFACE
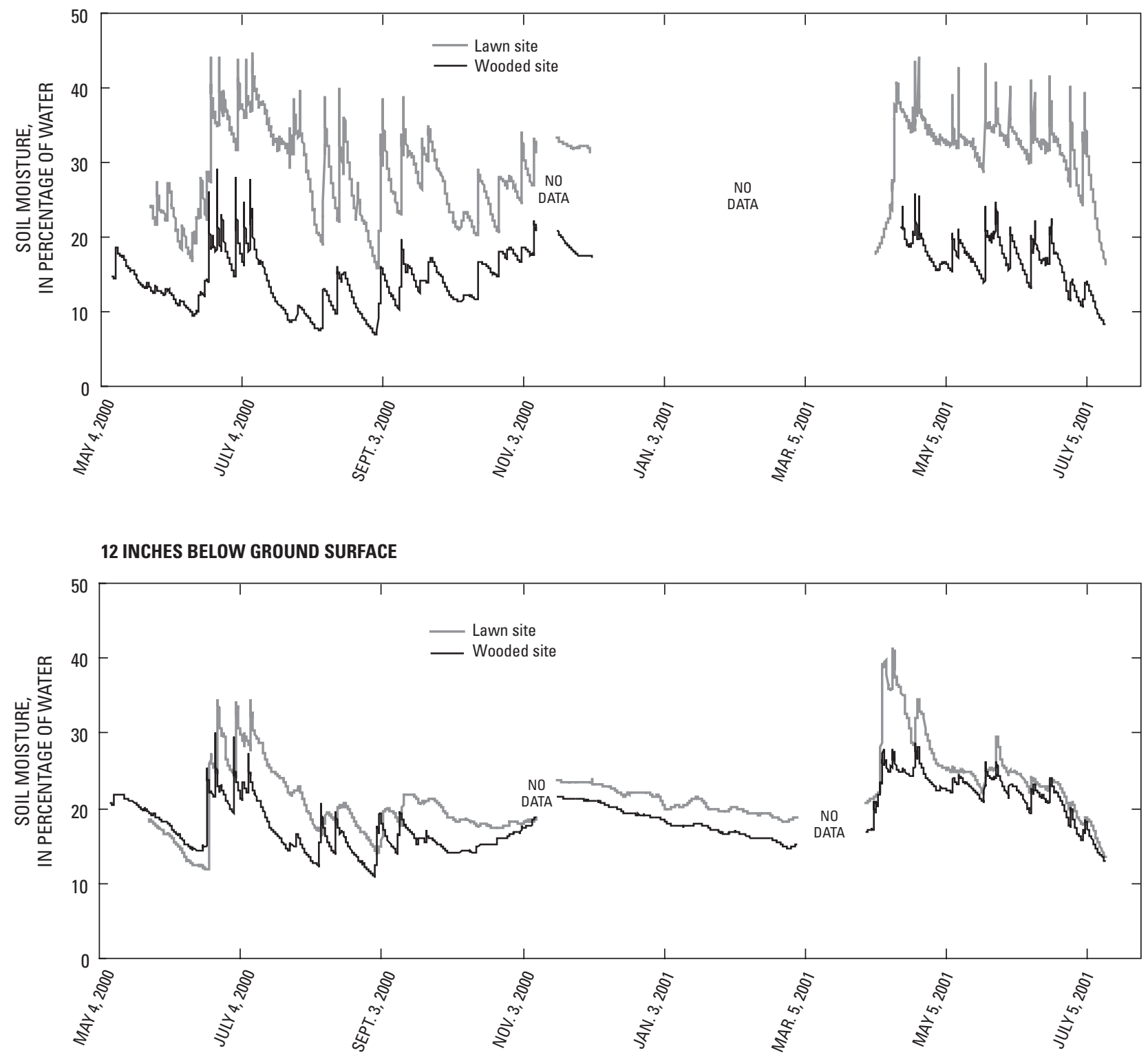

Figure 12. Soil moisture at 2 inches and 12 inches below ground surface, Butternut Lake lawn and wooded catchments, northern Wisconsin. 


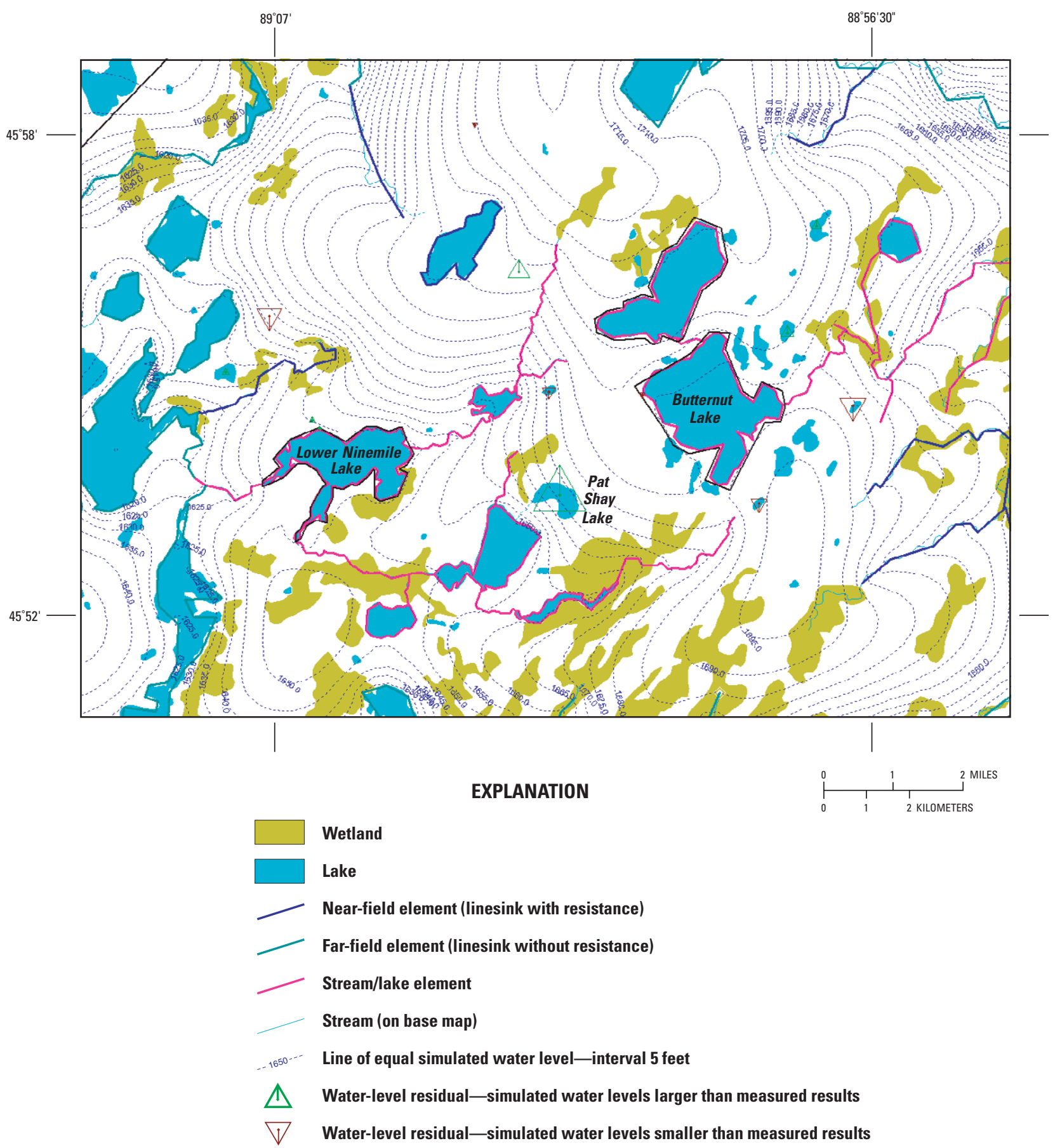

Figure 13a. Simulated water table and water-level residuals for modeled area, northern Wisconsin. The water-level residual symbols point upward when simulated results are larger than measured results and point downward when simulated results are smaller than measured results. The size of the largest symbol (Pat Shay Lake) represents a residual of 16.25 feet. 


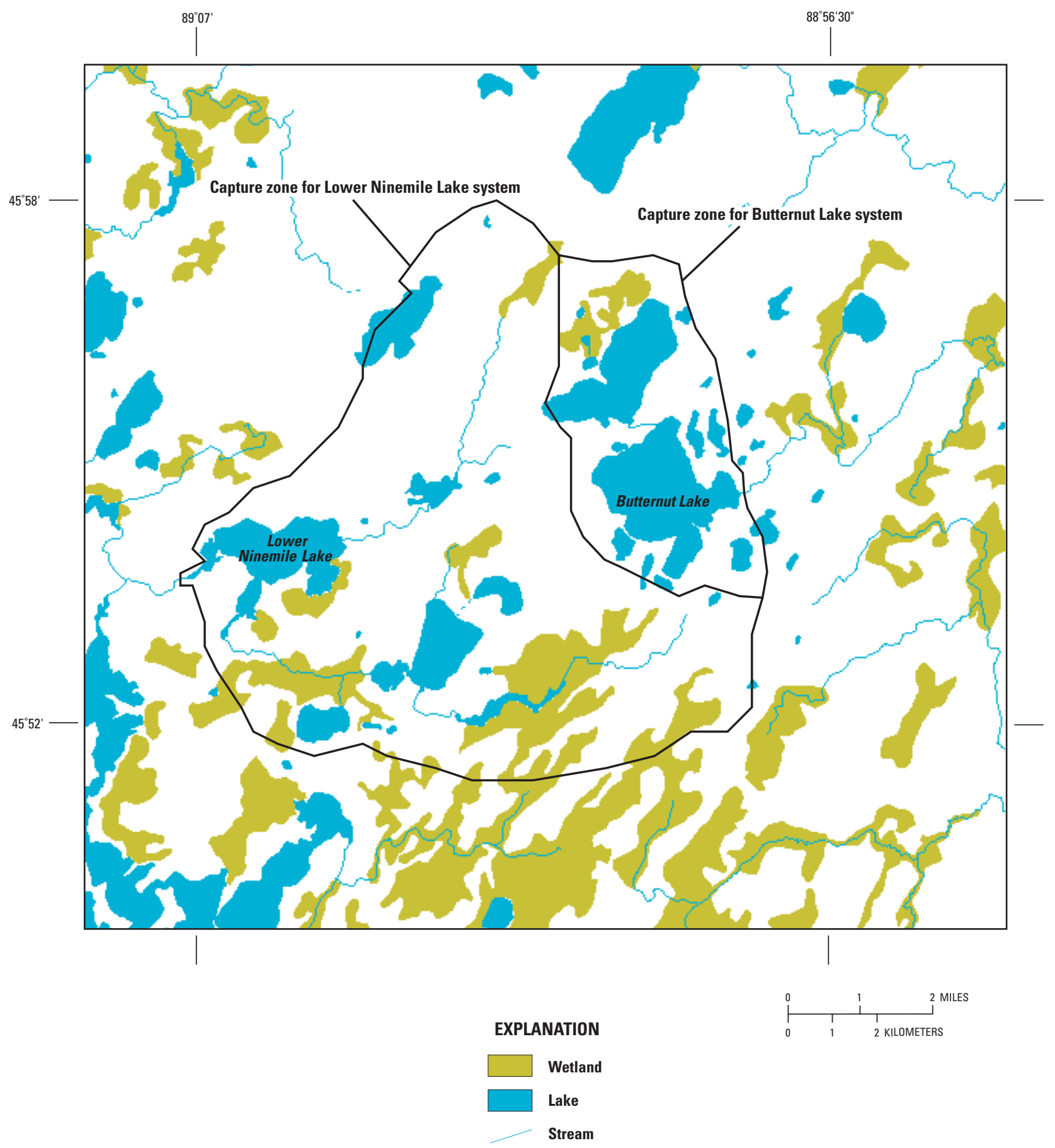

Figure 13b. Model-simulated lake and tributary capture zones, northern Wisconsin. 
Table 8. Estimated ground-water recharge from Lower Ninemile Lake surface catchments, northern Wisconsin

\begin{tabular}{|c|c|c|c|c|c|c|}
\hline & \multicolumn{3}{|c|}{ Lawn } & \multicolumn{3}{|c|}{ Woods } \\
\hline & Low & Intermediate & High & Low & Intermediate & High \\
\hline $\begin{array}{l}\text { Recharge rate } \\
\quad \text { (inches per year) }\end{array}$ & 8.0 & 10.0 & 12.0 & 10.0 & 12.0 & 14.0 \\
\hline $\begin{array}{l}\text { Annual volume of ground } \\
\text { water recharged } \\
\text { (gallons) }\end{array}$ & 4,862 & 6,078 & 7,294 & 4,488 & 5,386 & 6,284 \\
\hline
\end{tabular}

area. Therefore, the ground-water system is not affected by the heterogeneity that occurs near ice-block lakes. However, Lower Ninemile Lake is regulated according to powergeneration and water-storage needs rather than simple natural inputs and outputs of water. The lake-level regulation results in changing lake levels that are periodic and are characterized by winter drawdown, usually mid- to late October, with a subsequent recovery period (or drawup) beginning in mid-February until late spring (fig. 14). The lowering of lake levels increases the gradient of the ground-water-flow system to the lake (fig. 15a); the recovery period results in short-term reversals in gradient so that flow is not toward the lake (fig 15b). Approximately 4-6 weeks after the initiation of drawup, the ground-water system re-equilibrates and is again characterized by flow from the land to the lake, although with a lower gradient than during periods of lake drawdown (fig. 15c).

A simple mass-balance calculation was done to estimate the streamflow from the surface catchments monitored at the sites to the ground-water system. The surface areas of the lawn and wooded catchments were multiplied by recharge estimates for the lawn and wooded catchments. The estimates bracket the ground-water-model results but were varied spatially because the amount of measured runoff appreciably was higher in the lawn catchment than in the woods catchments. Although the actual recharge rate is not known, a range of recharge rates was used to calculate the volume recharged to the ground-water system listed in table 8 .

The flows from the surface catchments monitored in this study can be compared to the flows from the larger regional system using a streamflow-inspection line in the GFLOW model. The simulated quantity of water flowing through a vertically oriented cross section can be obtained. For the approximate width of the Lower Ninemile Lake lawn and woods ( $24 \mathrm{ft}$ ), the simulated regional streamflow equals $77,090 \mathrm{ft}^{3} / \mathrm{yr}$ for the lawn catchment and 70,590 $\mathrm{ft}^{3} / \mathrm{yr}$ for the woods catchment, of which the catchments monitored during this study accounted for about 1 percent of the ground water discharged to the lake through this section. Therefore, although areas adjacent to lakes clearly are important for surface runoff into the lake, most ground water discharged to the lake is from areas not adjacent to the lake. This comparison demonstrates that off-lake development has the potential to affect a lake's hydrology and water quality through the ground-water system, even if surface runoff effects are not expected to be appreciable.

\section{Butternut Lake Site}

The Butternut Lake site has characteristics typical of kettle lakes in northern Wisconsin. The sediments are more heterogeneous than near flowage lakes and are characterized by low conductivity, silt, and clay units that usually extend beneath the lake and onto nearshore areas (Kenoyer and Anderson, 1989). This heterogeneity results in more complex ground-water-flow patterns. Butternut Lake is not regulated; rather, lake stages are controlled by natural inputs and outputs of water and are not characterized by the dramatic gradient reversals observed at Lower Ninemile Lake.

At the Butternut Lake site, low-conductivity material was noted in cores near the lake and in the woods (appendix 1), and it has a local effect on the lake/ground-water interaction. The areas where clay was noted in the boring are areas where the shallow ground-water levels are higher than the surrounding ground-water system-both horizontally (fig. 16) and vertically (fig. 17). The flow system is notably more complex than that measured at Lower Ninemile Lake (fig. 15). The effect of the clay is twofold: first, the associated recharge mound can form a barrier to ground-water flow from the west and reduce the amount of ground water discharged to the lake. The shape of this mound (or the effect of the clay layer) often changessometimes it is more an oval recharge mound in the lower woods around P5, leaving P3 and sometimes P6 unaffected, but at other times the mound is elongated where the P3, P5, and P6 water levels all are mounded. Second, the clay serves as a restriction to vertical flow. Therefore, the ground-water flow is divided into a shallow component and a deep component, with little interchange expected between components. This division of ground-water flow 


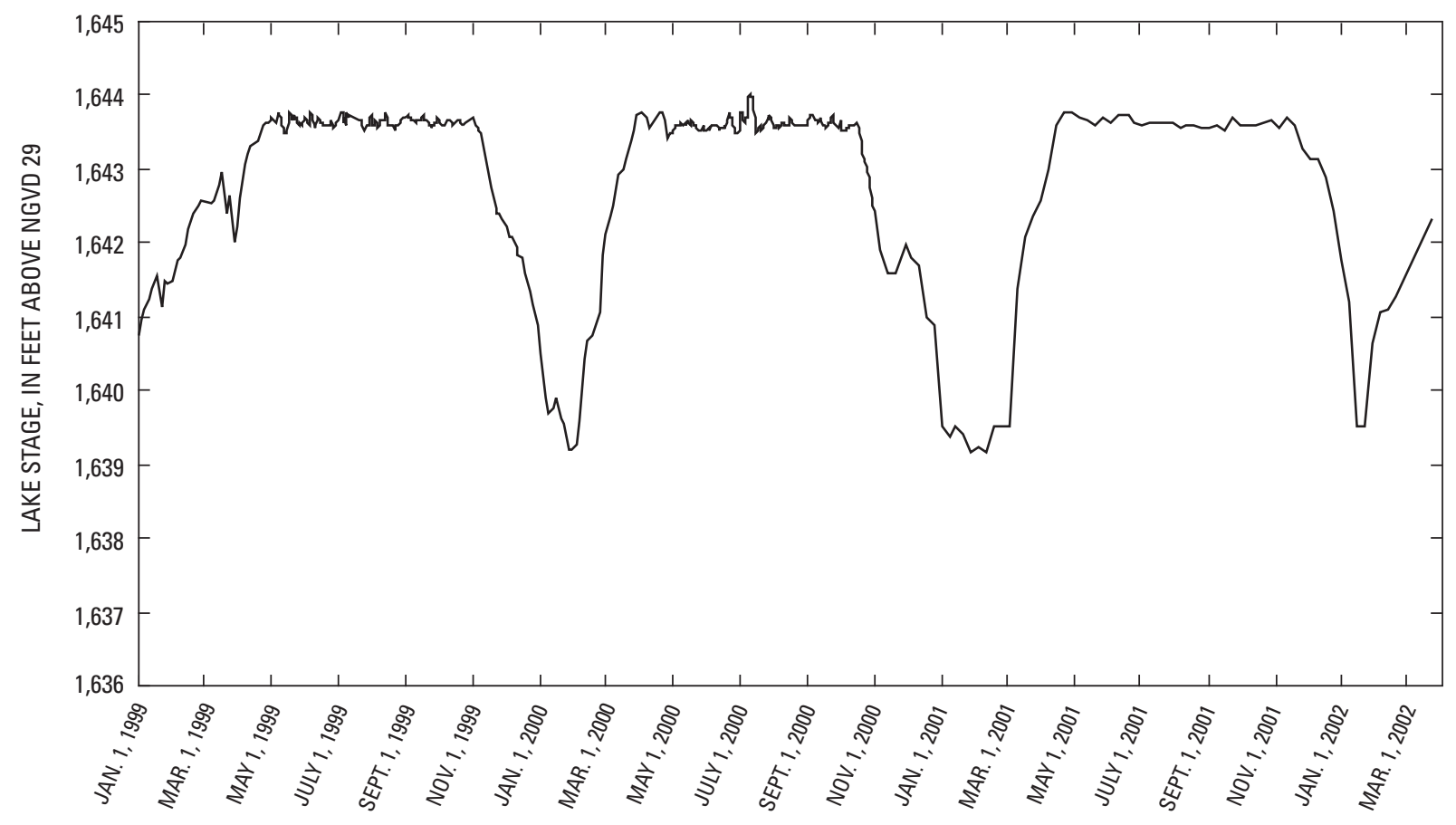

Figure 14. Lower Ninemile Lake levels, northern Wisconsin, January 1, 1999, to March 1, 2002.

effects the lake-edge buffers on ground-water-transported constituents. For example, transport from areas upgradient of the clay unit likely will flow under the clay unit during times of flow toward the lake, bypassing the buffer-strip roots. The presence of a clay layer near the lake also will reduce the likelihood that the buffer-strip roots will intercept any potential contaminants carried by the distant ground water. Nearshore ground-water constituents, on the other hand, will be more focused into the buffer-strip root zone by the low-conductivity clay.

Although Butternut Lake is not regulated, the flow system is relatively complex spatially and temporally (fig. 16). Unlike the Lower Ninemile site, the regional model is not suitable (because of its large scale) for incorporating the geologic detail necessary to simulate the Butternut Lake site. Therefore, a comparison of ground water recharged from the local basins to the water of the regional system cannot be made. Water levels measured at the Butternut Lake site indicate that the flow is predominantly toward Butternut Lake from April through February and away from the lake during March. Although a comparison of the importance of regional flow and site-derived flow cannot be made, water levels collected during this study indicate that water recharged from the site likely will discharge to the lake for most of the year.

\section{Nutrient Concentrations}

\section{Surface Runoff}

Samples were collected during runoff events caused by rainfall and snowmelt from November 1999 through September 2001. A total of 76 water samples collected by the lawn samplers and 67 water samples collected by the woods samplers were analyzed. The results of all of the samples collected and analyzed are given in appendix 2 . The maximum, minimum, mean, and median at each site can be found in table 9 .

During the 23-month study period, no samples were collected at Kentuck Lake site 2 woods site because there was no surface runoff at this catchment. The woods at this site could be characterized as being the most mature of all the woods in the study are and consist mostly of sugar maple and hemlock. The ground cover is mostly immature sugar maple and a thick mat of decomposing organic matter and moss. The mature canopy, thick organic mat, and low slope (lowest of all the wooded sites - 10 percent) may have contributed to the lack of surface runoff.

Comparing the median nutrient concentrations from lawns with the median nutrient concentrations from woods across sites, no apparent and consistent pattern for these concentrations is found. For example, at the Lower 

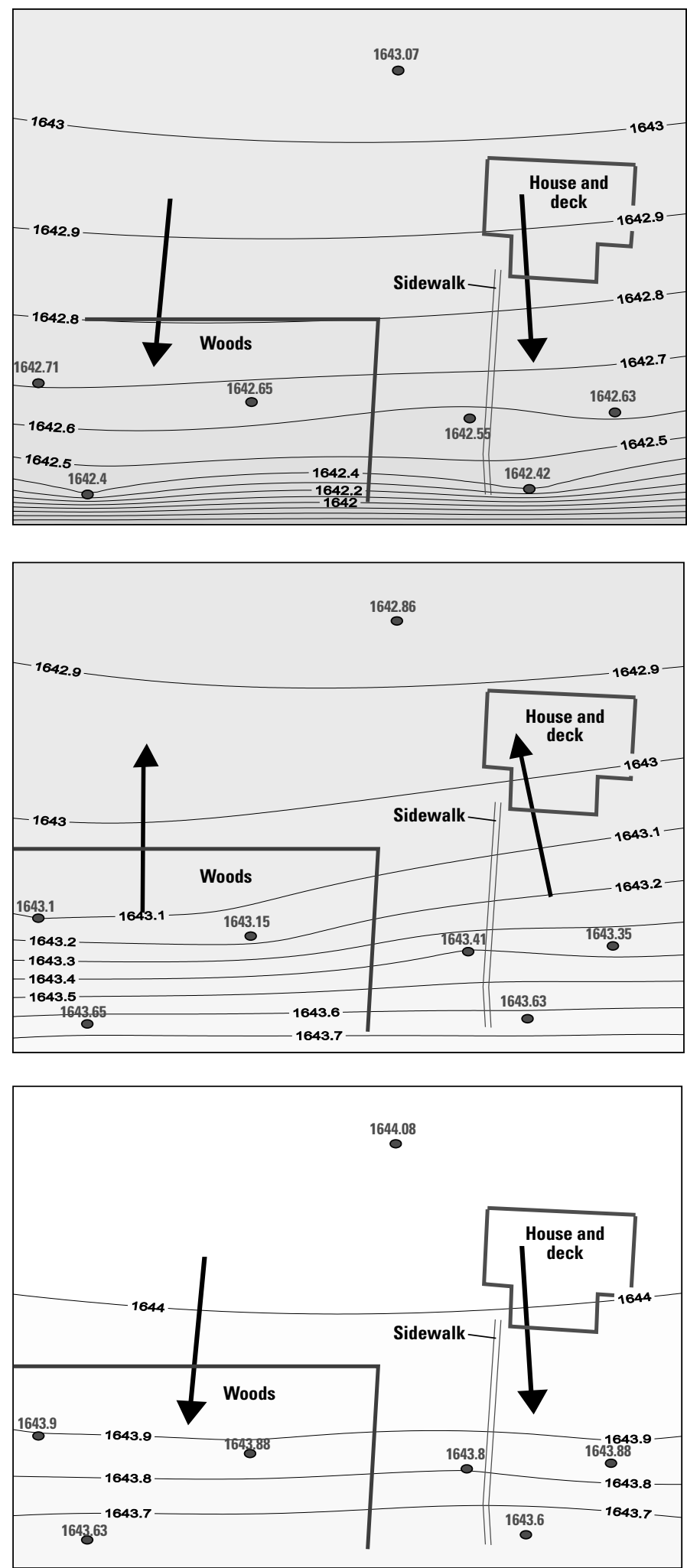

\section{A}

Water-table contour map from November 15, 2000, illustrating how the ground-water gradient increases to the lake as a result of winter drawdown of lake stage. Lake elevation is 1641.6 feet above NGVD 29. Contour interval 0.1 foot.

\section{B}

Water-table contour map from April 2, 2000, showing how spring drawup of lake levels causes reversal in the ground-water gradient. Lake elevation is 1643.75 feet above NGVD 29. Contour interval 0.1 foot.

\section{C}

Water-table contour map from July 24,2000 , weeks after drawup; ground-water system has re-equilibrated and flow is once again to the lake but with less gradient. Lake elevation is 1643.63 feet above NGVD 29. Contour interval 0.1 foot.

Figures 15. Water-table maps of Lower Ninemile Lake site showing the interconnectedness of the shallow aquifer and lake for three time periods, northern Wisconsin. 

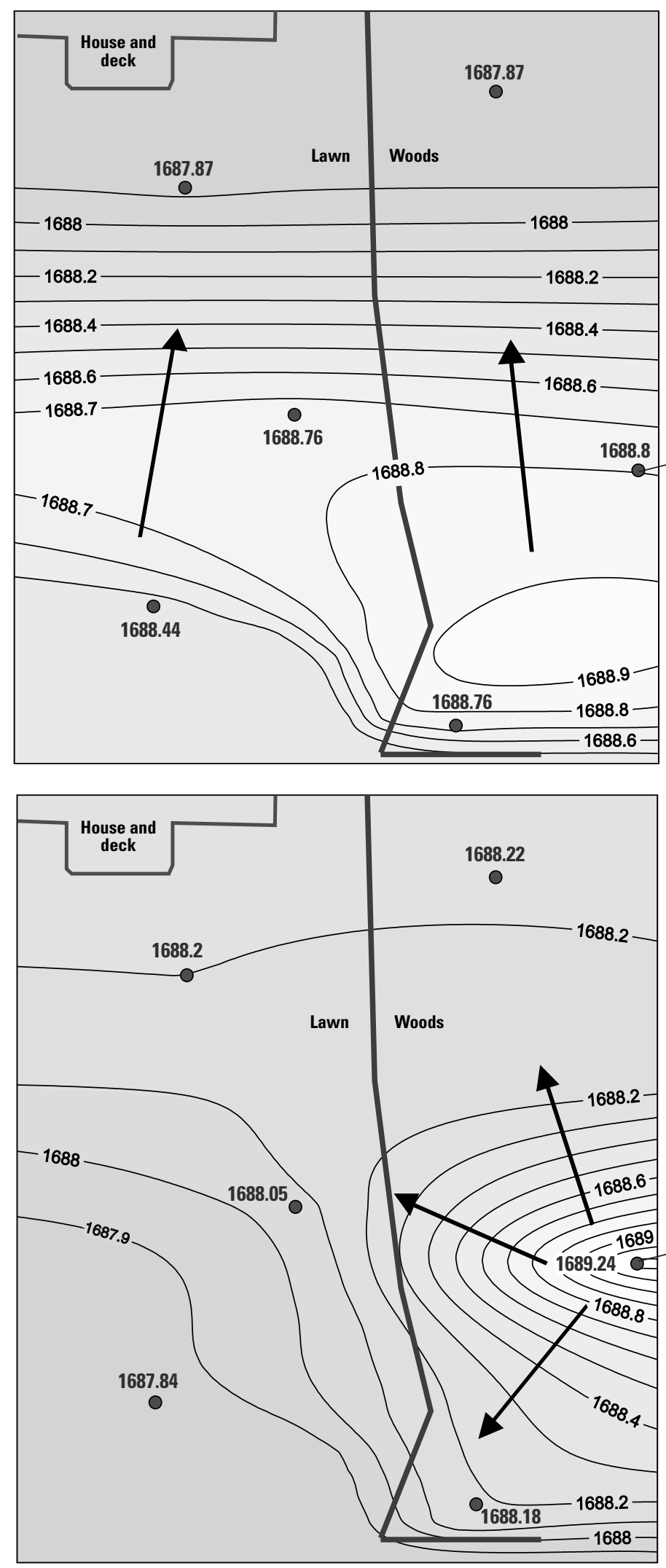

Water-table contour map from February 25, 2000, during the ground-water reversal that naturally occurs in early spring.

Water-table contour map from May 29, 2000, showing how the clay layer has a localized effect and perches those water levels surrounding well P5.

Figures 16. Ground-water contour maps of Butternut Lake site for two time periods, northern Wisconsin. 


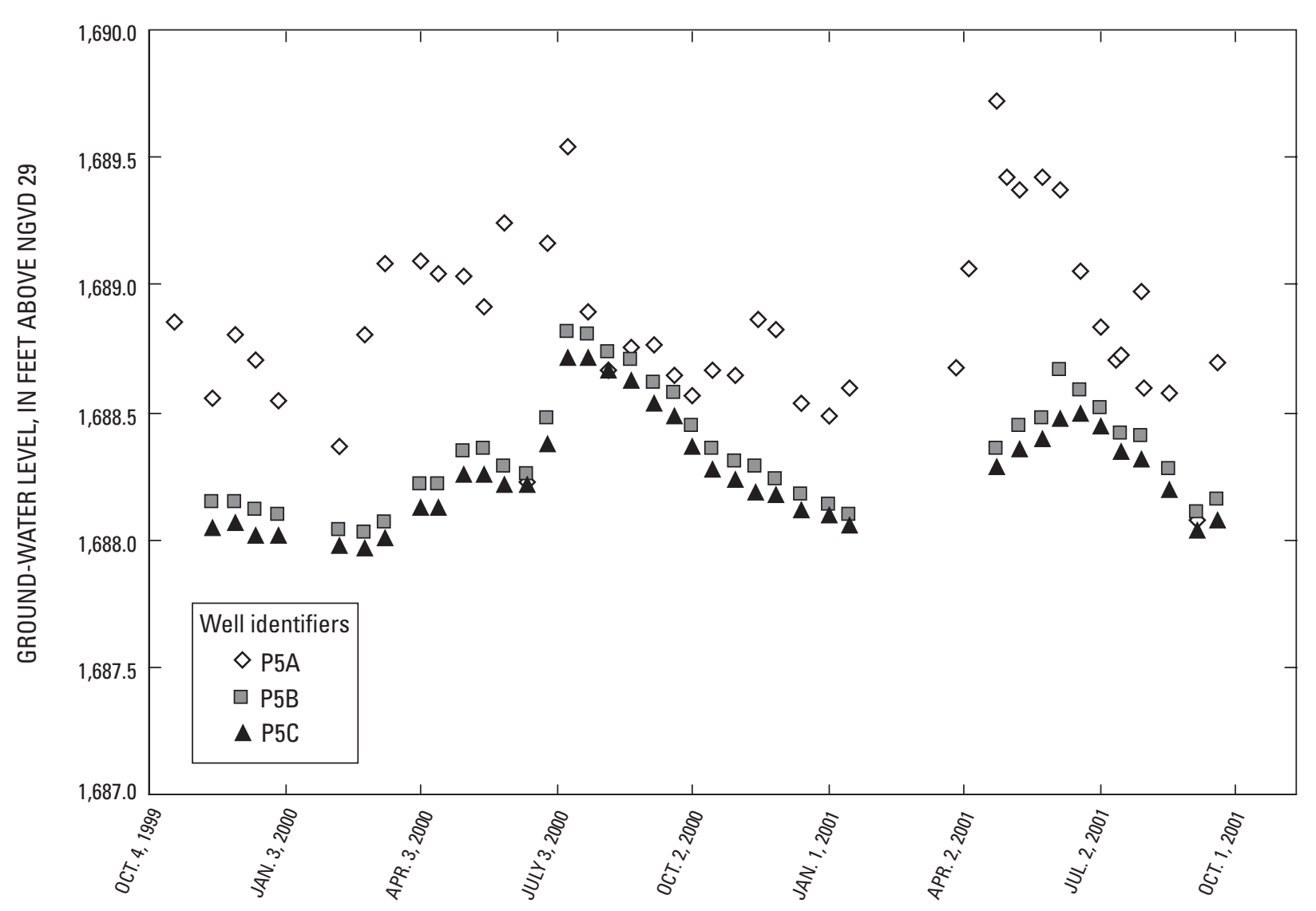

Figure 17. Vertical gradients at the Butternut Lake site P5 well nest, northern Wisconsin.

Ninemile Lake site, the median dissolved phosphorus and total phosphorus concentration for the lawn samples was greater than those for the woods samples. In contrast, the median concentration of dissolved phosphorus and total phosphorus concentration for the lawn samples was less than the median concentration for the woods samples at the Butternut Lake site.

A nonparametric Wilcoxon rank-sum test (Conover, 1980) was used to determine whether the differences between the lawn and woods median concentrations were statistically significant. At the Lower Ninemile Lake site, median ammonia nitrogen concentration for the lawn site was significantly different $(\mathrm{P}<0.05)$ from that for the woods. None of the other nutrient concentrations were significantly different. At the Butternut Lake site, median concentrations for nitrate plus nitrite nitrogen, dissolved total phosphorus, and total phosphorus for the lawn site were significantly different $(\mathrm{P}<0.05)$ from those for the upper woods. When comparing the lawn with the lower woods, the median nitrate plus nitrite nitrogen, total Kjeldahl nitrogen, and total phosphorus concentrations were significantly different $(\mathrm{P}<0.05)$. At the Anvil Lake site only, the median dissolved phosphorus concentration at the lawn site was significantly different from the median concentration at the woods 4 site.

All sample-concentration data from lawn sites were composited and compared to composited sample nutrient-concentration data from wooded sites. The maximum, minimum, mean, median, and number of samples is given in table 10 .

The median nutrient concentrations from the wooded sites were all greater than those from the lawn sites except for nitrate plus nitrite nitrogen (table 10 and fig. 18). The nonparametric Wilcoxon rank-sum test was used to determine whether the concentrations from the lawn sites were statistically significantly different from these of the wooded sites. All of the median nutrient concentrations for lawns were significantly different $(\mathrm{P}<0.05)$ from the median nutrient concentrations for woods.

The median concentrations at other sites throughout the country, as reported in the literature, can be found in table 11. The median concentrations from this study are within the range of those from the other literature (table 11), although the composited median concentrations from this study are closer to the lower end of the range of literature values. 


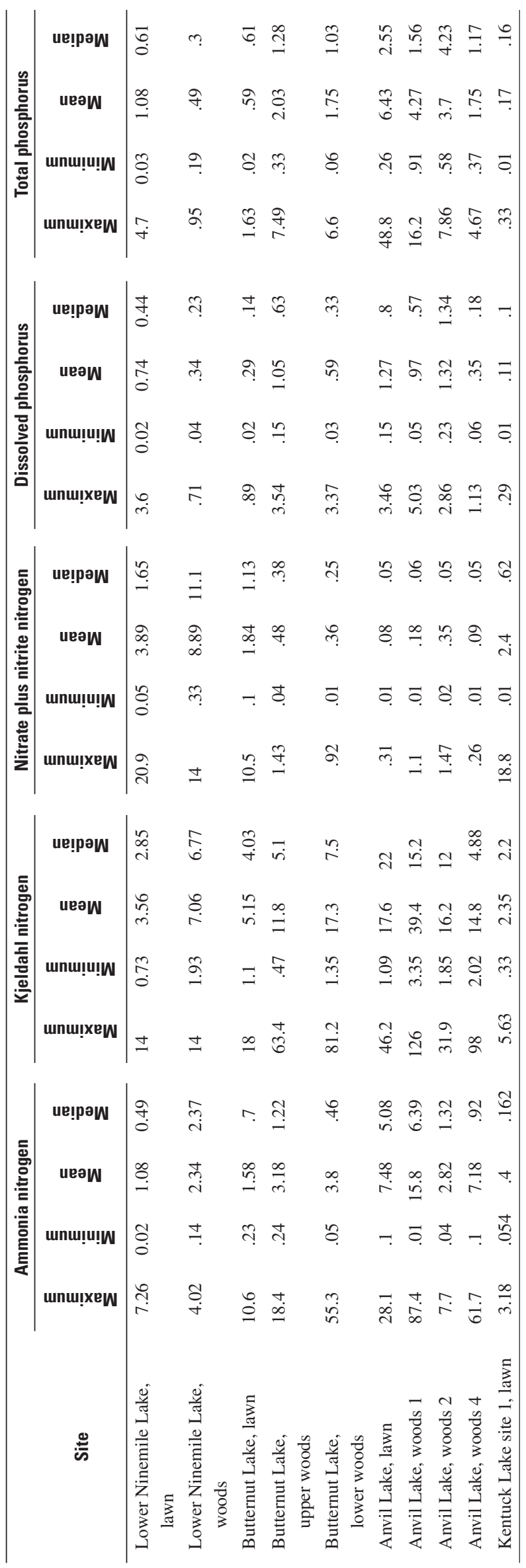


Table 10. Composited values for nutrient concentrations, and number of samples collected at the lawn and woods runoff samplers at all sites for all storms, northern Wisconsin

LAWN SAMPLES

Number of samples $=76$

Concentrations in milligrams per liter

\begin{tabular}{lccccc}
\hline & $\begin{array}{c}\text { Ammonia } \\
\text { nitrogen }\end{array}$ & $\begin{array}{c}\text { Nitrate plus } \\
\text { nitrite } \\
\text { nitrogen }\end{array}$ & $\begin{array}{c}\text { Total Kjeldahl } \\
\text { nitrogen }\end{array}$ & $\begin{array}{c}\text { Dissolved } \\
\text { phosphorus }\end{array}$ & $\begin{array}{c}\text { Total } \\
\text { phosphorus }\end{array}$ \\
\hline Maximum & 28.1 & 20.9 & 46.2 & 3.60 & 48.8 \\
Minimum & 0.02 & .01 & .33 & .01 & .009 \\
Mean & 1.87 & 2.43 & 2.78 & .52 & 1.46 \\
Median & .42 & .77 & 2.78 & .17 & .32
\end{tabular}

\section{WOODS SAMPLES}

Number of samples $=67$

Concentrations in milligrams per liter

\begin{tabular}{lccccc}
\hline & $\begin{array}{c}\text { Ammonia } \\
\text { nitrogen }\end{array}$ & $\begin{array}{c}\text { Nitrate plus } \\
\text { nitrite } \\
\text { nitrogen }\end{array}$ & $\begin{array}{c}\text { Total Kjeldahl } \\
\text { nitrogen }\end{array}$ & $\begin{array}{c}\text { Dissolved } \\
\text { phosphorus }\end{array}$ & $\begin{array}{c}\text { Total } \\
\text { phosphorus }\end{array}$ \\
\hline Maximum & 87.4 & 14.0 & 126 & 5.03 & 16.2 \\
Minimum & .013 & .01 & .47 & .03 & .06 \\
Mean & 6.05 & 1.07 & 18.4 & .74 & 2.26 \\
Median & .98 & .21 & 7.38 & .33 & 1.12 \\
\hline
\end{tabular}

Table 11. Comparison of runoff concentrations from other studies and data collected in this study of northern Wisconsin [All concentrations in milligrams per liter; --, not analyzed; USGS, U.S. Geological Survey]

\begin{tabular}{|c|c|c|c|c|c|c|}
\hline Citation & Land use & $\begin{array}{c}\text { Ammonia } \\
\text { nitrogen }\end{array}$ & $\begin{array}{l}\text { Nitrate plus } \\
\text { nitrite }\end{array}$ & $\begin{array}{l}\text { Kjeldahl } \\
\text { nitrogen }\end{array}$ & $\begin{array}{c}\text { Dissolved total } \\
\text { phosphorus }\end{array}$ & $\begin{array}{c}\text { Total } \\
\text { phosphorus }\end{array}$ \\
\hline Cole and others, 1997 & Turf & 4.0 & 3.5 & & & 1.0 \\
\hline King and others, 2001 & Stream draining turf & .03 & .50 & -- & -- & .13 \\
\hline Dennis, 1986 & Residential & -- & -- & -- & -- & .22 \\
\hline Garn, 2002 & Fertilized lawn & 1.07 & .12 & 5.9 & .77 & 2.85 \\
\hline Garn, 2002 & Unfertilized lawn & .63 & .14 & 5.1 & .38 & 1.8 \\
\hline Thomann, 1987 & Urban & -- & -- & 1.3 & -- & .066 \\
\hline Bannerman and others, 1996 & Urban & .24 & .49 & 1.0 & .09 & .29 \\
\hline Barten, 1997 & Lawn & 3.6 & 1.5 & 5.8 & 1.0 & 1.45 \\
\hline Stuntebeck, USGS, written commun., 2002 & Fertilized lawn & -- & -- & -- & .33 & 1.12 \\
\hline Stuntebeck, USGS, written commun., 2002 & Unfertilized lawn & -- & -- & -- & .64 & 1.34 \\
\hline U.S. Environmental Protection Agency, 1983 & Residential & -- & -- & -- & .14 & .38 \\
\hline Garn, 2002 & Woods & 4.3 & .24 & 9.8 & 2.0 & 4.0 \\
\hline Thomann, 1987 & Woods & -- & -- & .85 & -- & .14 \\
\hline Dennis, 1996 & Woods & -- & -- & -- & -- & .055 \\
\hline This study & Lawn & 0.42 & 0.77 & 2.8 & 0.17 & 0.32 \\
\hline This study & Woods & .98 & .21 & 7.4 & .33 & 1.12 \\
\hline
\end{tabular}



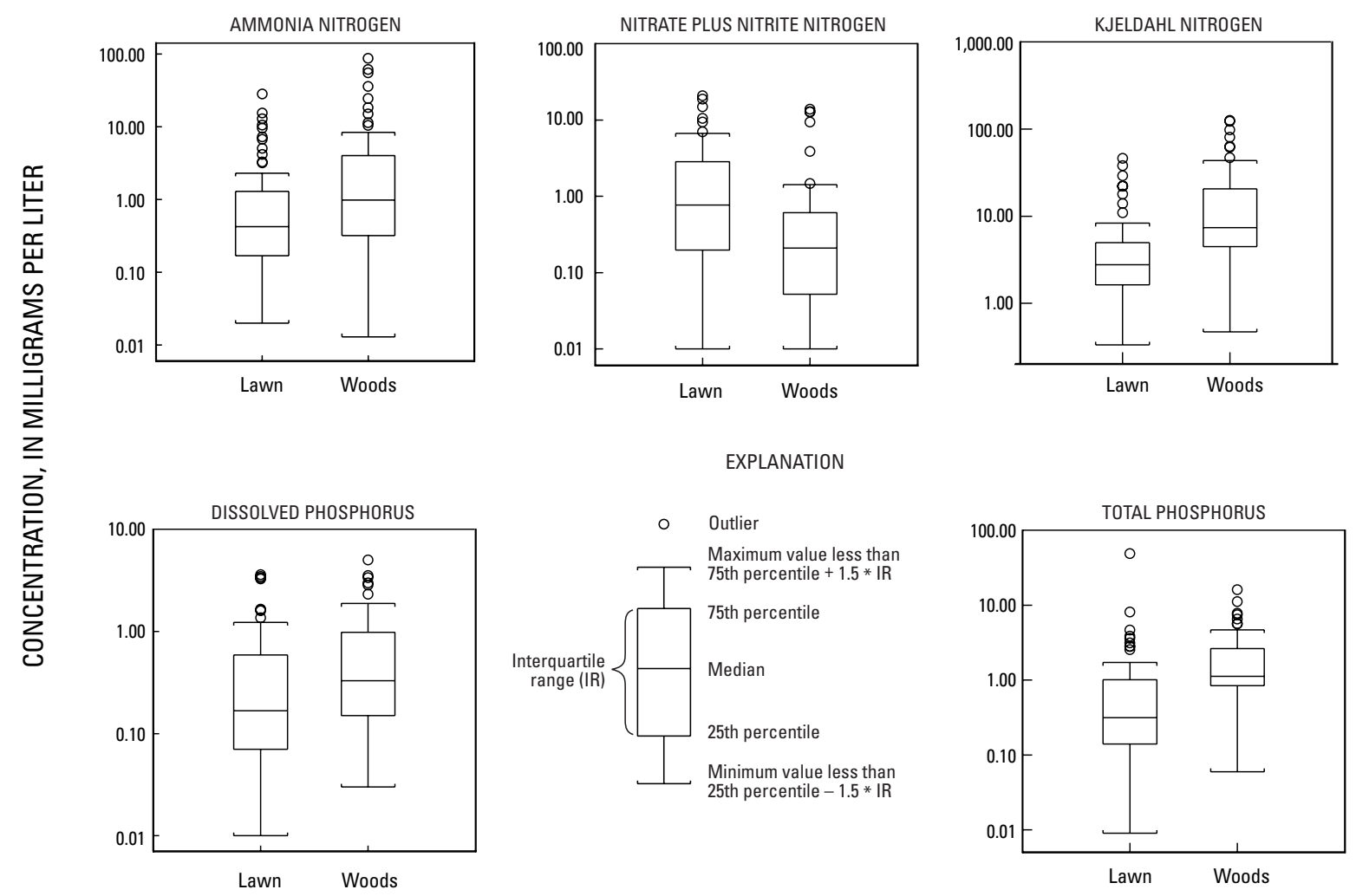

Figure 18. Concentrations of selected constituents for all surface-runoff samples collected by lawn and woods samplers, northern Wisconsin.

\section{Ground Water}

The water-table wells and piezometers at the Lower Ninemile and Butternut Lake sites were sampled for chemical analysis during February, June, and August 2001. The results are discussed in the following sections below; the complete results are included in appendix 3 .

\section{Lower Ninemile Lake Site}

At Lower Ninemile Lake, nutrient (nitrogen and phosphorus) concentrations in shallow ground water (figs. 19 and 20) generally were less than those in surface runoff (fig. 18). Ground-water chemistry was more variable in lawn samples than either the woods samples or the upgradient-well (G5A) samples (figs. 19 and 20). In the shallow ground water, concentrations of nitrate plus nitrite and total phosphorus for lawn samples were appreciably higher than those for woods samples. Dissolved inorganic phosphorus and ammonia concentrations were similar in shallow ground water at both site types.
The dynamic nature of the ground-water chemistry also is evident in deeper ground water (B and C depths, figs. 21a, 21b, 22a, and 22b). Nutrient concentrations at depths are greater than those measured in the shallow ground water (for example, in G1C), an indication that areas distant from the lake affect the quality of water that discharges to the lake. This finding is consistent with the results of the ground-water-flow model simulation, which shows that an appreciable amount of the water discharged to the lake originated away from the near-lake areas.

Because the site is near a ground-water-discharge area (the shore of the lake) contributes to the temporal variability of water chemistry in two ways. First, it is an area of converging flowlines, so small changes in ground-water level could result in the sample being collected at a location with a different flowline and associated recharge area. Secondly, manipulation of lake stage reverses the gradient near the lake (fig. 15); therefore, infiltrated lake water (and reactions facilitated by the infiltrating water) may be affecting the ground-water chemistry at the site. 


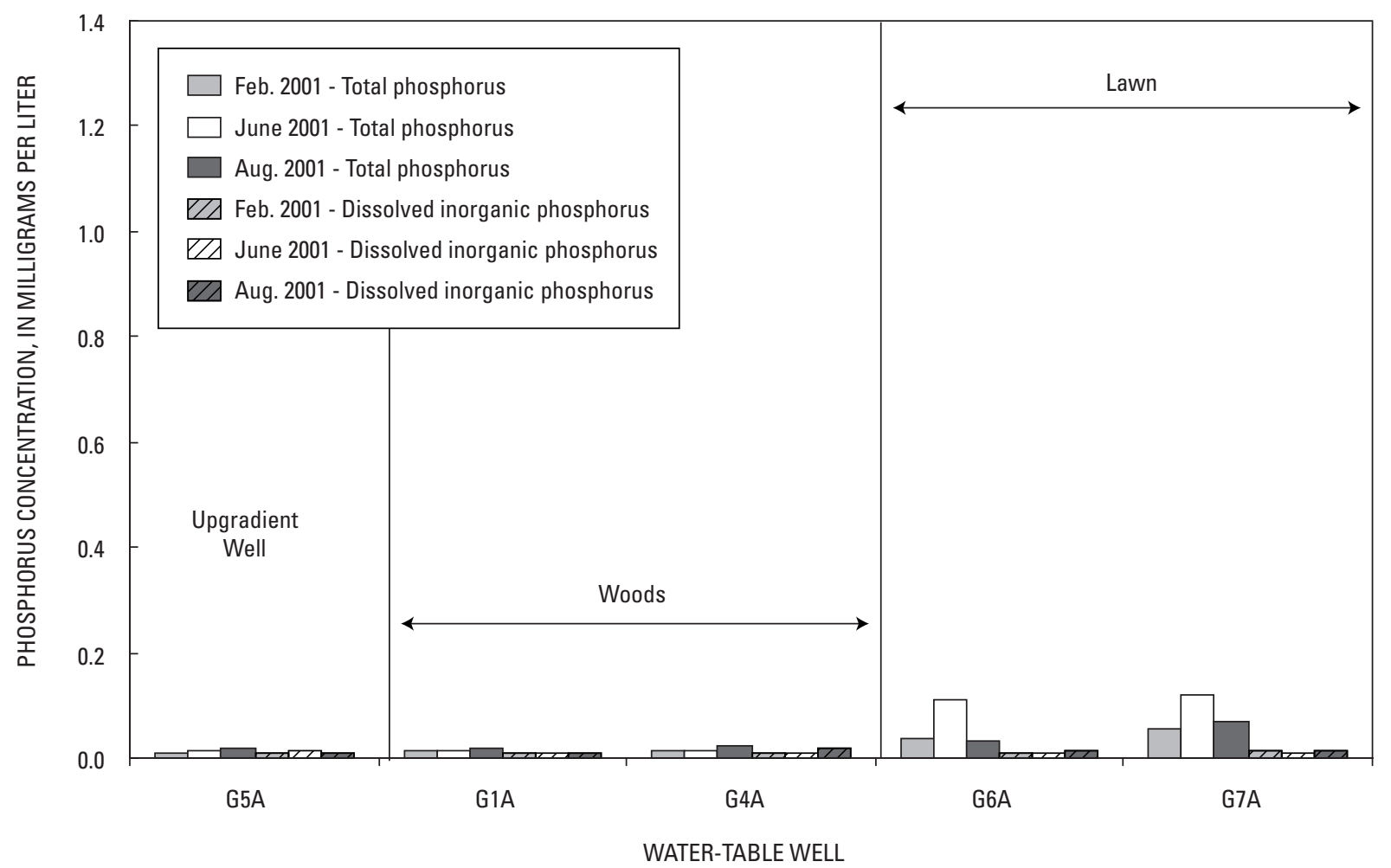

Figure 19. Phosphorus concentrations in the shallow ground-water system of the Lower Ninemile Lake site, northern Wisconsin.

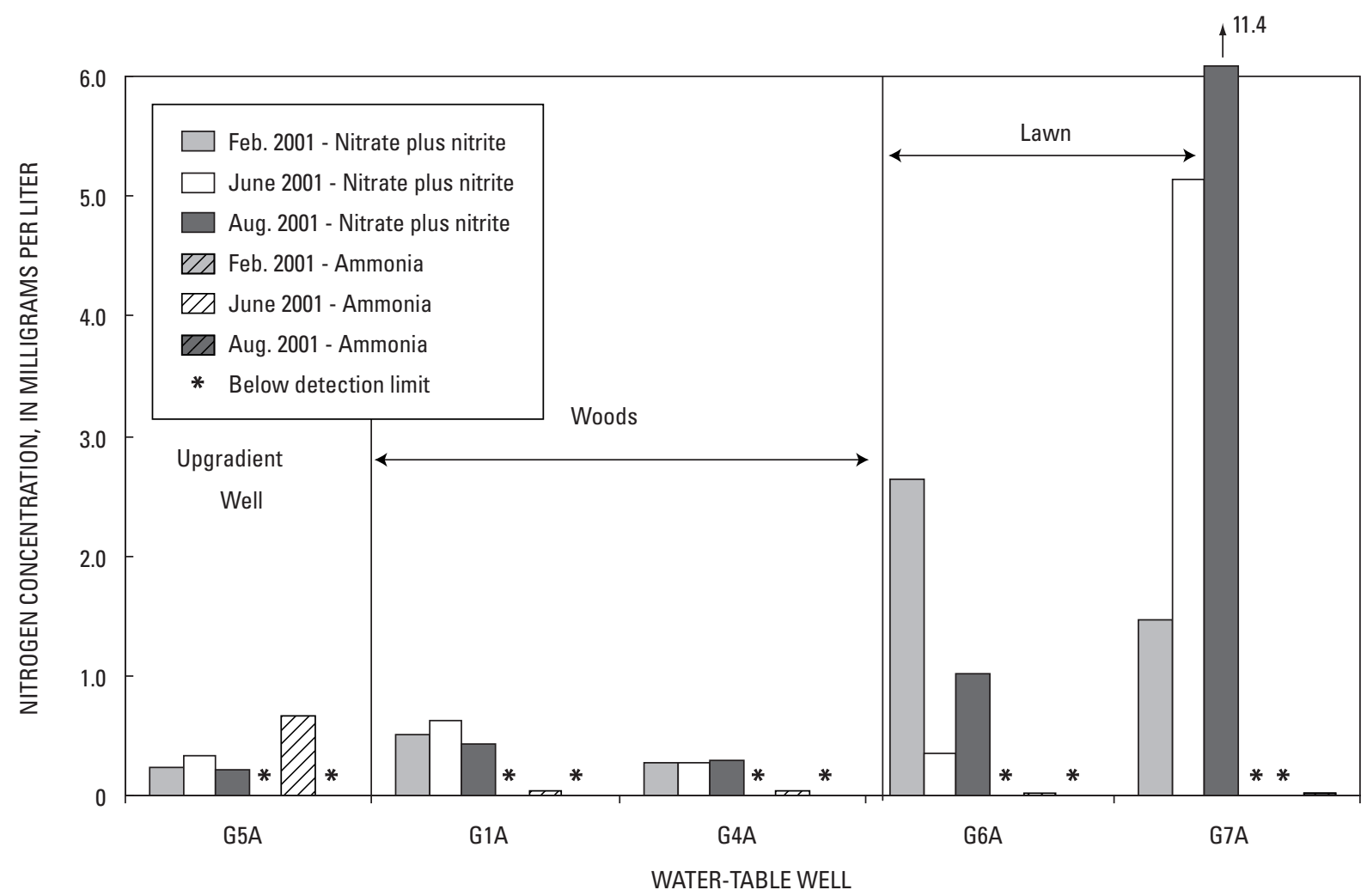

Figure 20. Nitrogen concentrations from the shallow ground-water system of the Lower Ninemile Lake site, northern Wisconsin. (All samples for total nitrogen were below detection limit.) 


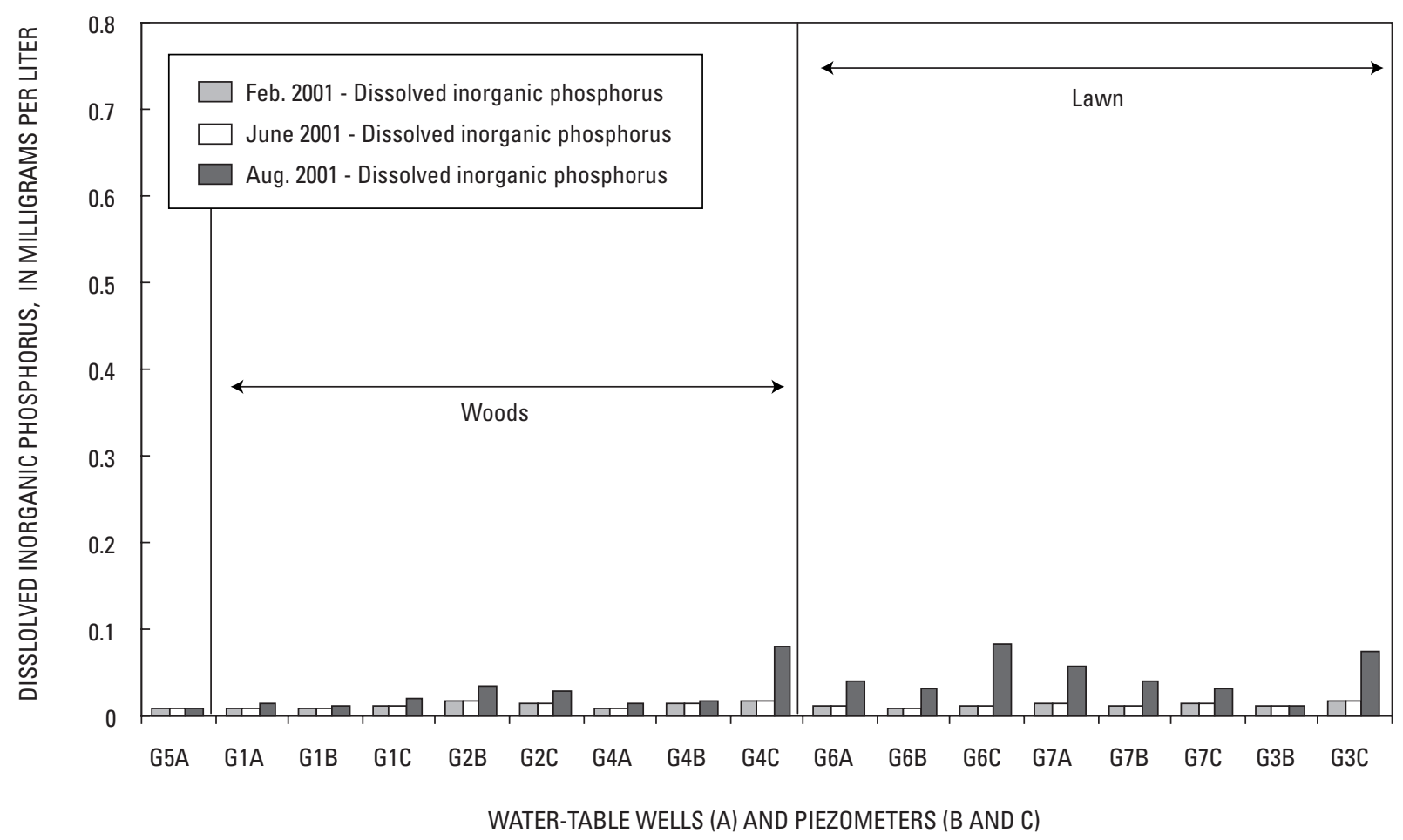

Figure 21a. Dissolved inorganic phosphorus concentrations in the shallow (A) and deep (B and $C$ ) ground-water systems of the Lower Ninemile Lake site, northern Wisconsin. (G5 is an upgradient well.)

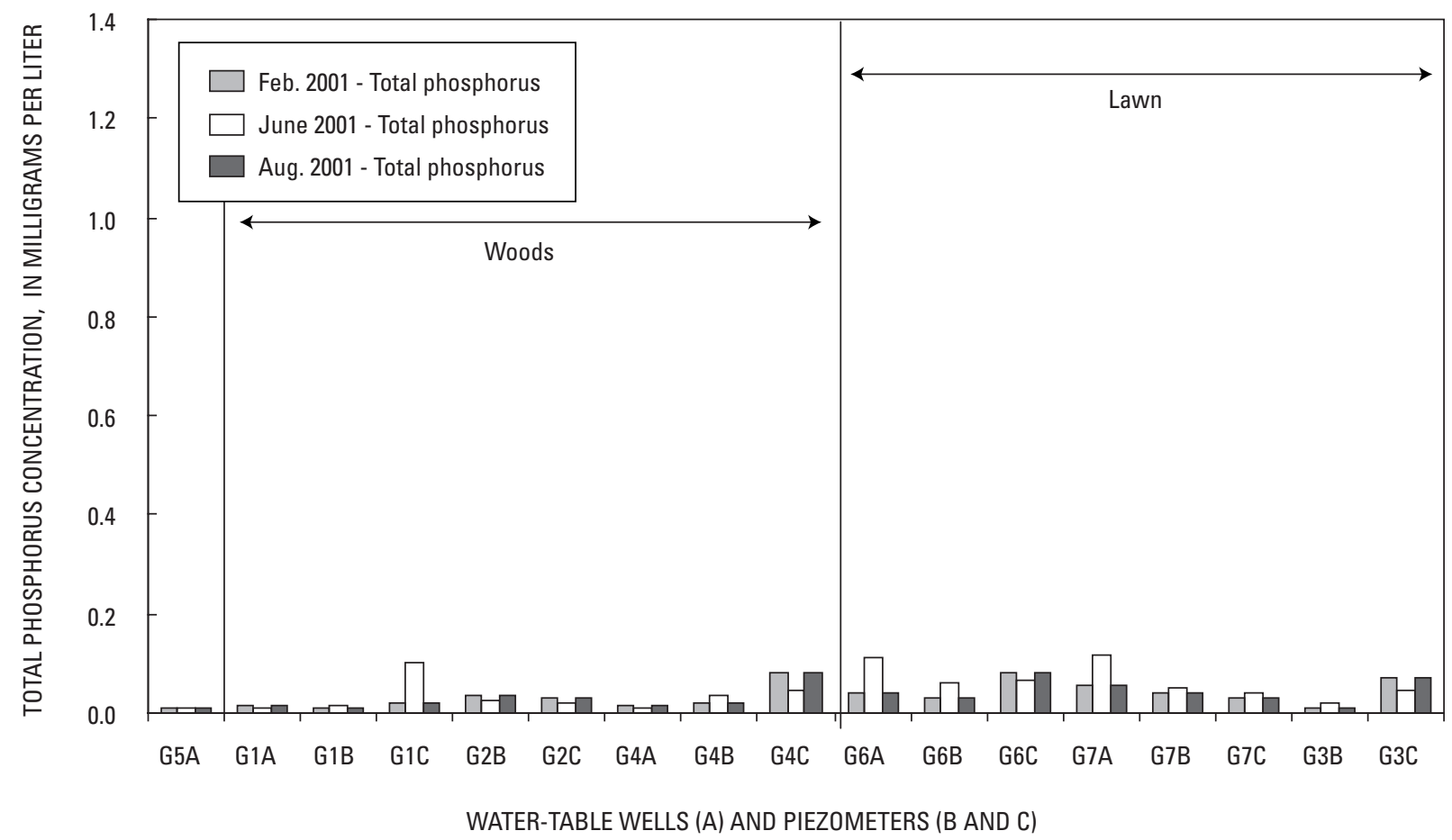

Figure 21b. Phosphorus concentrations from the shallow ( $A$ ) and deep ( $B$ and $C$ ) ground-water systems of the Lower Ninemile Lake site, northern Wisconsin. (G5 is an upgradient well.) 


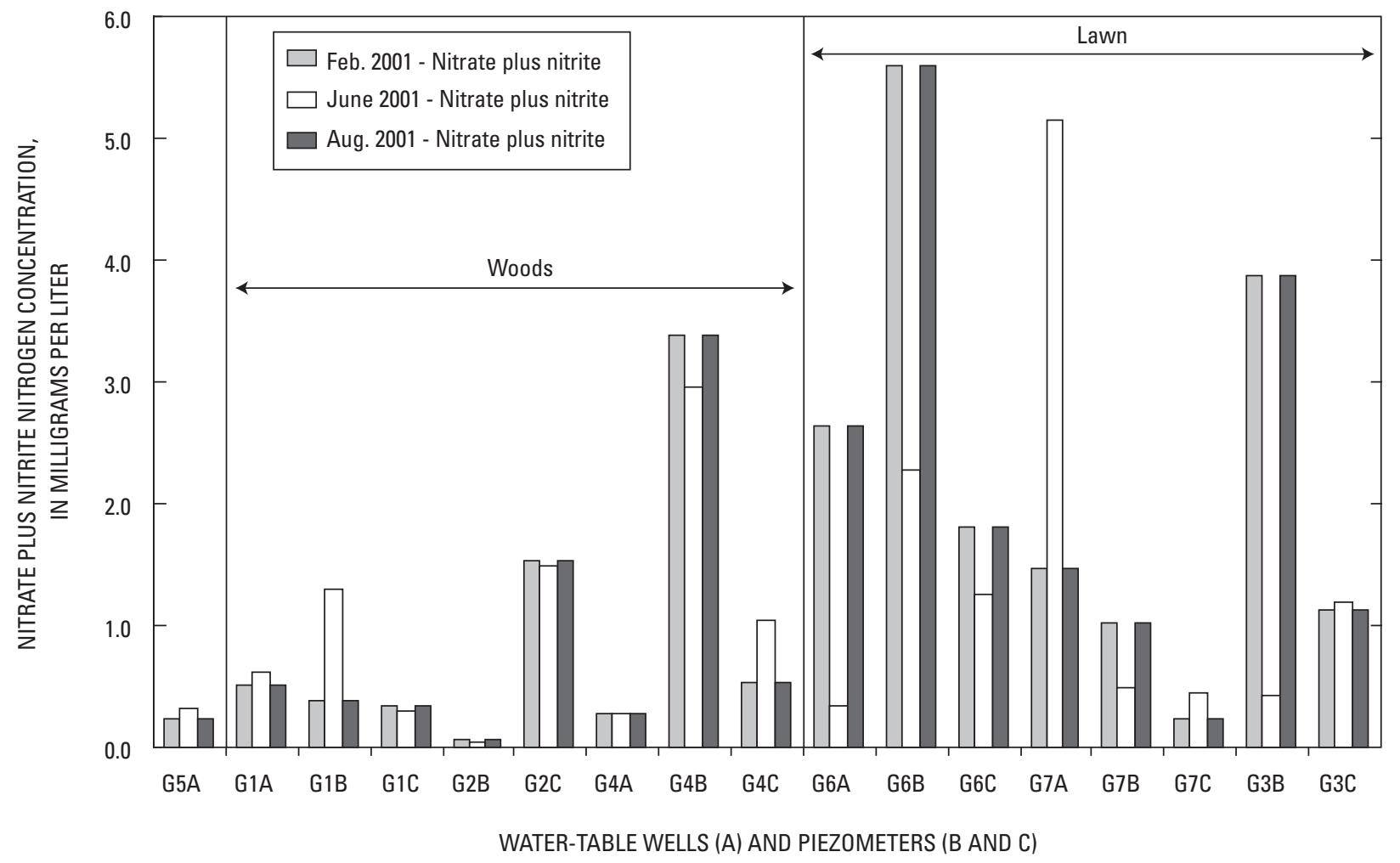

Figure 22a. Nitrate plus nitrite concentrations from the shallow $(A)$ and deep $(B$ and $C$ ) ground-water systems of the Lower Ninemile Lake site, northern Wisconsin. (G5 is an upgradient well.)

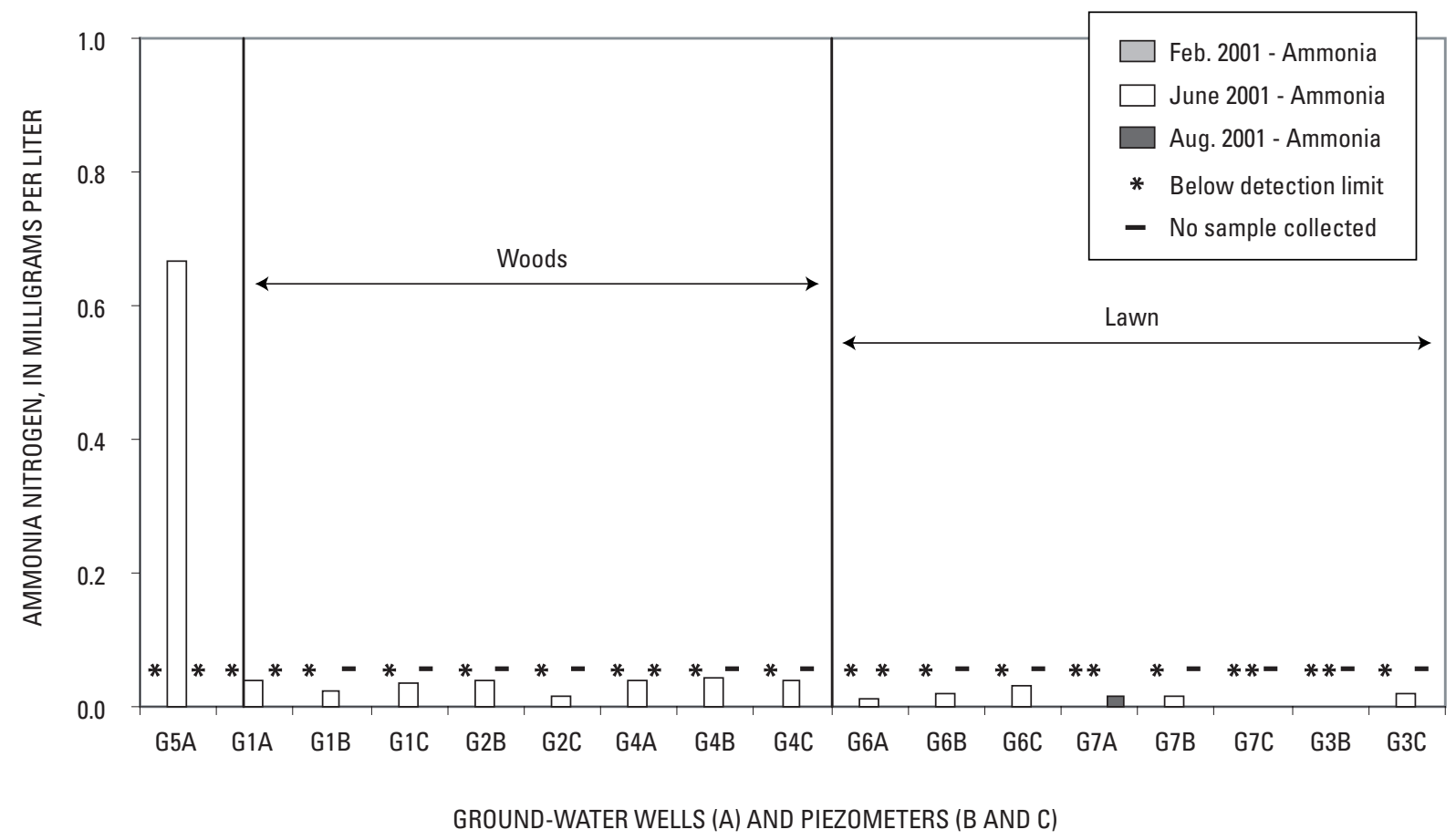

Figure 22b. Ammonia concentrations from the shallow ( $A$ ) and deep (B and C) ground-water systems of the Lower Ninemile Lake site, northern Wisconsin. (G5 is an upgradient well.) 


\section{Butternut Lake Site}

The ground-water-flow system is notably different at this site in that flow is both to the lake (late spring to early winter) and from the lake (late winter to early spring). Therefore, "upgradient" can refer to sites near to or distant from the lake. Another difference from other sites is that the shallow ground water was collected only from one location in the woods at this site, because the shallow water depth and presence of clay resulted in frozen shallow wells during the February sampling. Sufficient sample volume was obtained in the later well samplings at this site.

Unlike the Lower Ninemile Lake site where nutrient concentrations were similar in the two water-table wells at the lawn, the shallow ground-water samples at the Butternut Lake site demonstrate that ground water at various locations within the lawn vary in nutrient concentrations (figs. 23 and 24), presumably because of topographic position in the landscape (fig. 3). Generally, samples from the lawn slope (P2A) and away from the base of the slope (P4A) had lower nutrient concentrations than the lawn sample at the base of the slope (P3A). This difference might mean that surface-runoff-transported nitrogen and phosphorus constituents infiltrated at the bottom of the hill, before they reached P4A. In general, lawn samples had similar or greater nutrient concentrations than did samples of the shallow ground water underlying the woods, although this difference may be an artifact because of a smaller number of samples from the woods than from the lawns.

Similar to the Lower Ninemile Lake site, the variability in the shallow ground-water chemistry as reflected in the lawn samples from P3A was greater than that for the woods. The higher concentrations and greater variability of shallow ground-water chemistry at lawn well P3A indicate a more dynamic hydrologic setting than at any other site. The location on the flat area adjacent to the base of the slope likely resulted in increased recharge of lawnderived water, from a larger area of lawn than for the other lawn-sampling locations (P2 and P4, fig. 3). This result is consistent with the higher soil moisture measured at this location (fig. 12) and the deeper penetration of nutrients into the subsurface. At the other lawn catchments, less variability was noted in nutrient concentrations over time.

The dynamic nature of the nutrient ground-water chemistry again is indicated in both the shallow ground water and the deeper ground water sampled (B and C depths, figs. 25a, 25b, 26a and 26b). Higher nutrient concentrations at depth in areas where high nutrient concentrations are not seen in the shallow ground water (for example, in P1C) indicate that areas distant from the local recharge zone also are important for characterizing ground-water quality at the site. Moreover, the higher infiltration hypothesized in the $\mathrm{P} 3$ well and piezometer nest could explain the higher nitrogen concentrations measured deeper in the ground-water system-something not noted at any other well and piezometer nest.

\section{Nutrient Yields}

Although determining concentrations may provide insight into the water-quality process at a given location in the landscape, more important may be the constituent loads (concentration multiplied by water volume) and, ultimately, the yields (load divided by catchment area) from the different land uses.

Because nutrient loads are a product of water volume and concentration, the amount of runoff at these sites is an important factor in computing nutrient loads and the subsequent yields (load divided by catchment size). As shown in the Surface Runoff section, runoff from the lawn catchments was roughly an order of magnitude greater than runoff from the wooded catchment. This increased volume will be a major factor in explaining the higher nutrient yields from lawns than from the woods. Yields for nutrients, in pounds per acre, were computed for the surface-runoff samples at all of the sites (lawn and woods). Load and yield data for the surface-runoff samples are given in appendix 4.

\section{Surface Runoff}

Event-to-event yields can be variable. For example, from the 11 sites monitored, single-event contributions ranged from 14 to 73 percent of the total ammonia nitrogen load for the 11-month study period. Large proportions of annual loads generally are attributed to snowmelt events; but in the example here, the largest ammonia nitrogen loads at 5 of 11 catchments were from rainfall events.

For all constituents, the median nutrient yields from lawn catchments always were greater than the median nutrient yields from the woods (fig. 27); for ammonia nitrogen, nitrate plus nitrite, and total phosphorus median yields, the difference was at least an order of magnitude. A nonparametric Wilcoxon test was used to demonstrate that yields for all nutrient constituents from the lawn catchments were significantly different $(\mathrm{P}<0.05)$ from those from the wooded catchments. Although nutrient concentrations were greater in the woods, the runoff water volumes were the most important factor in determining 


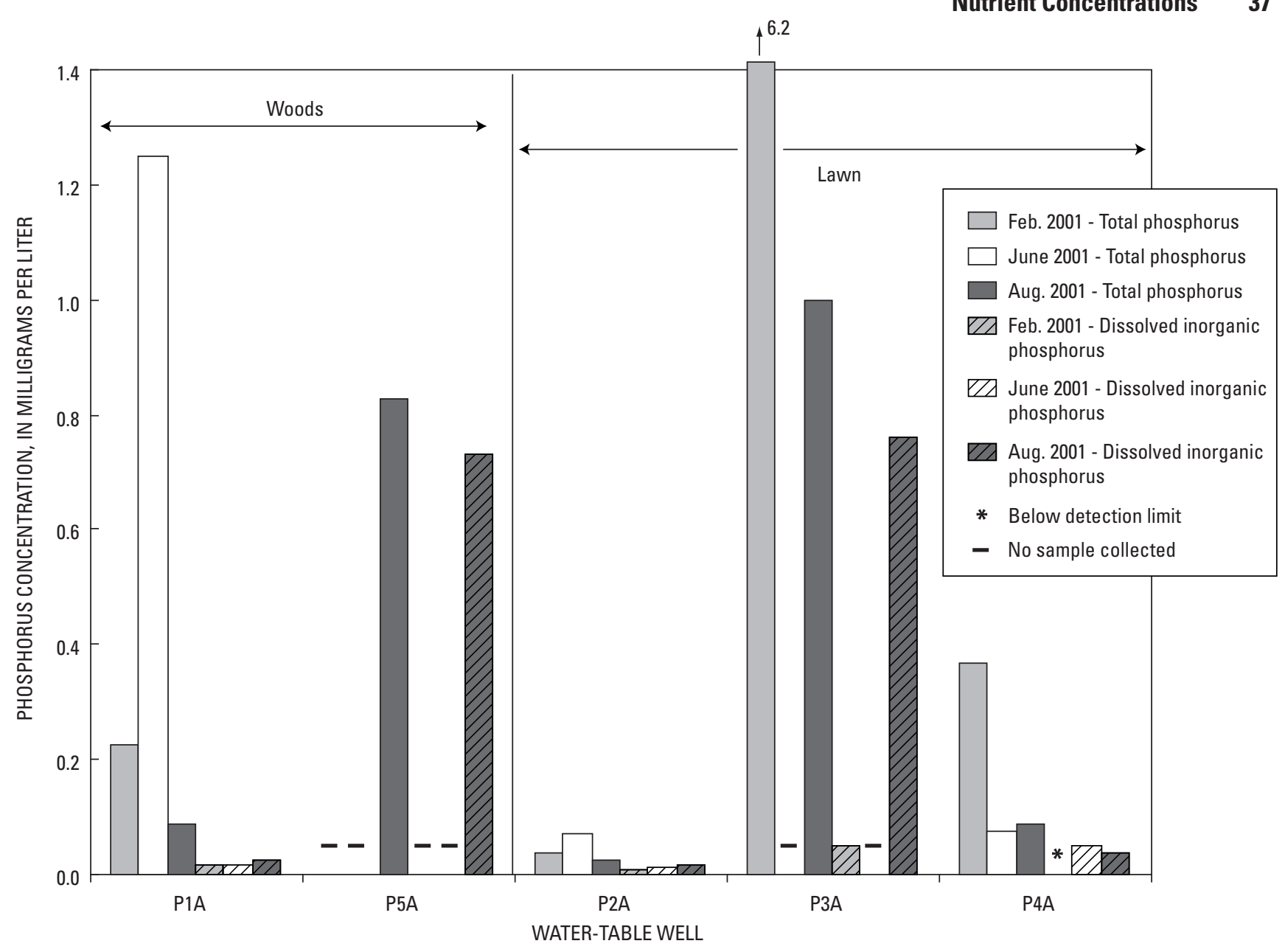

Figure 23. Phosphorus concentrations from the shallow ground-water system of the Butternut Lake site, northern Wisconsin.

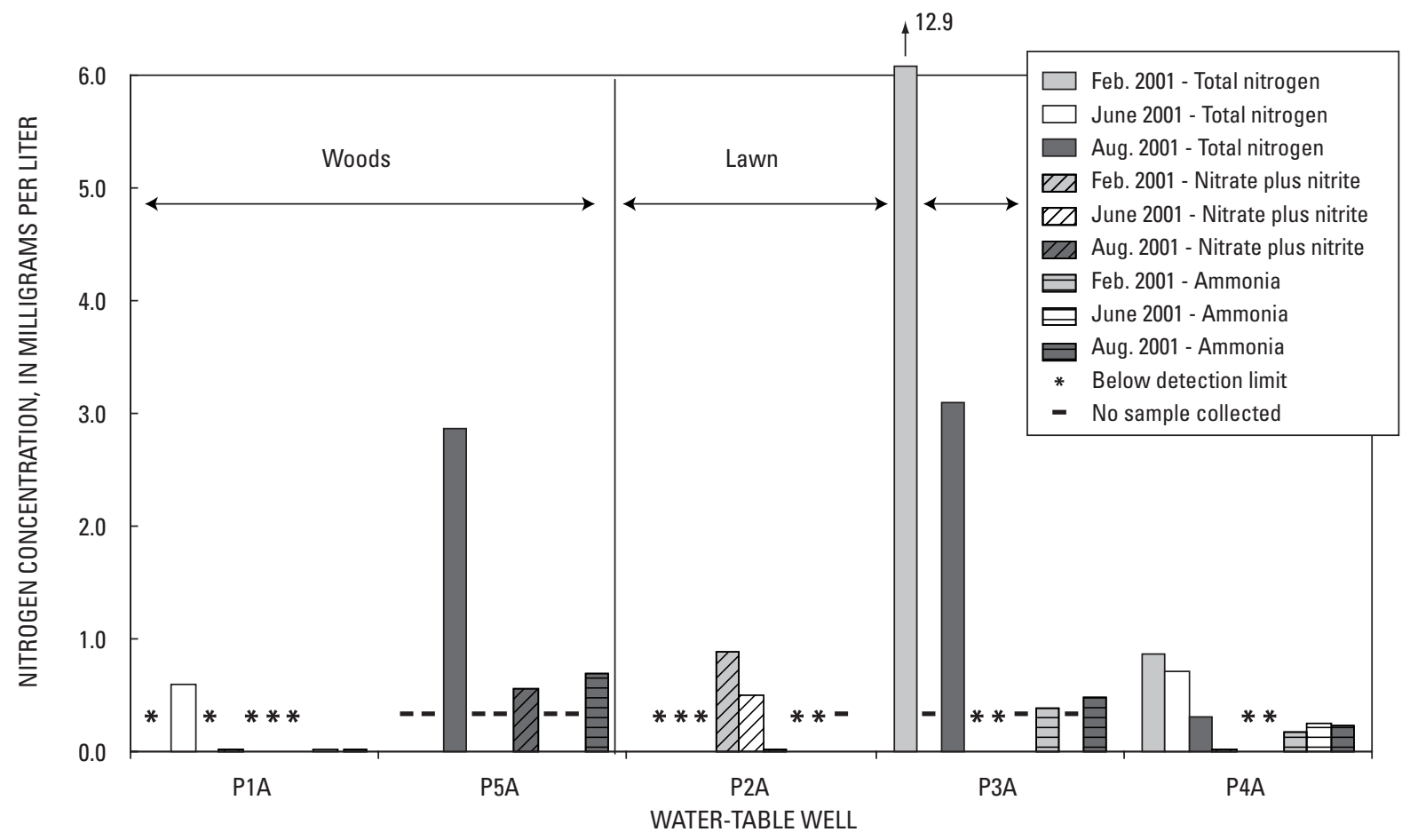

Figure 24. Nitrogen concentrations from the shallow ground-water system of the Butternut Lake site, northern Wisconsin. 


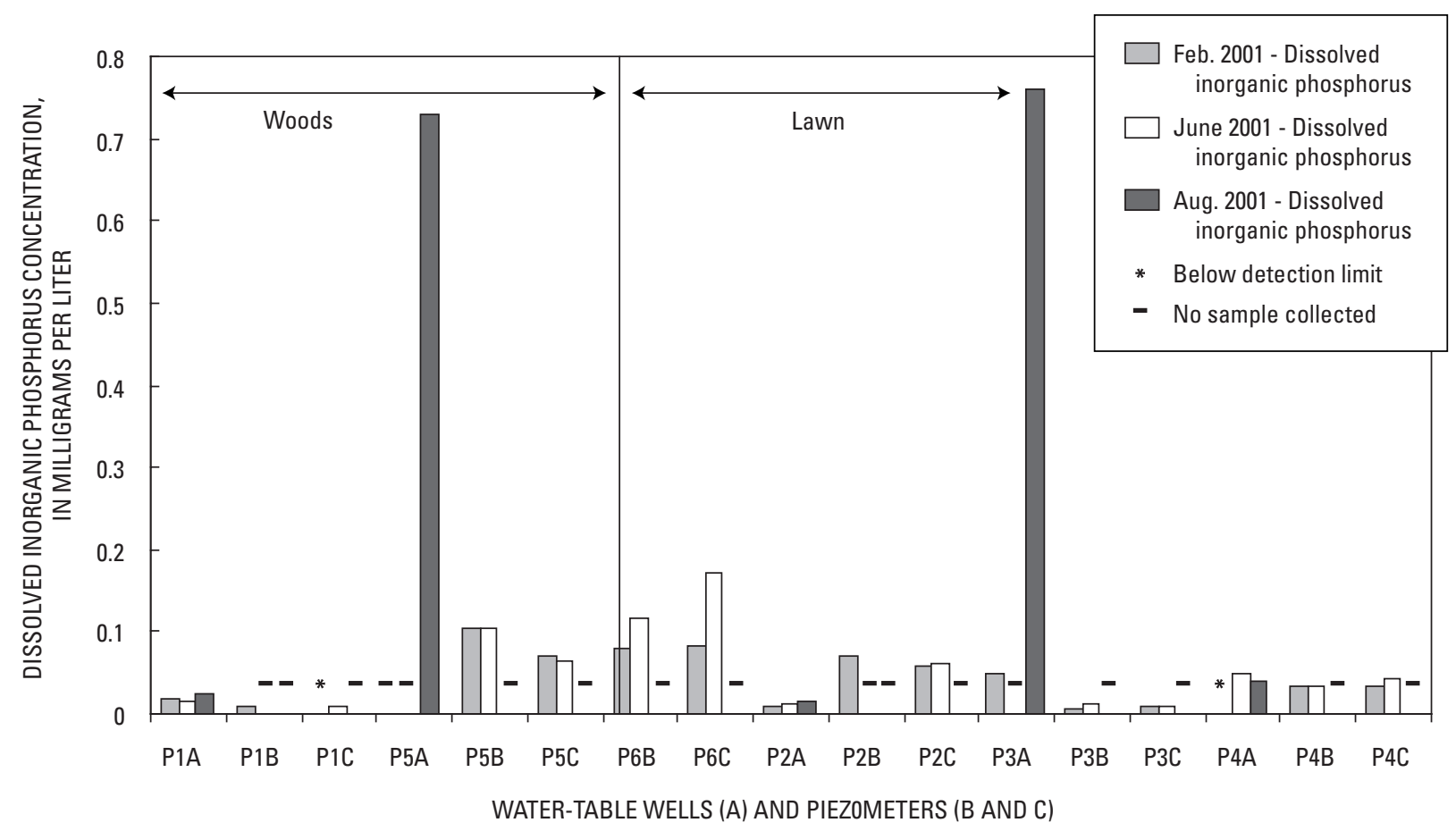

Figure 25a. Dissolved inorganic phosphorus concentrations from the shallow $(A)$ and deep (B and $C$ ) ground-water systems of the Butternut Lake site, northern Wisconsin.

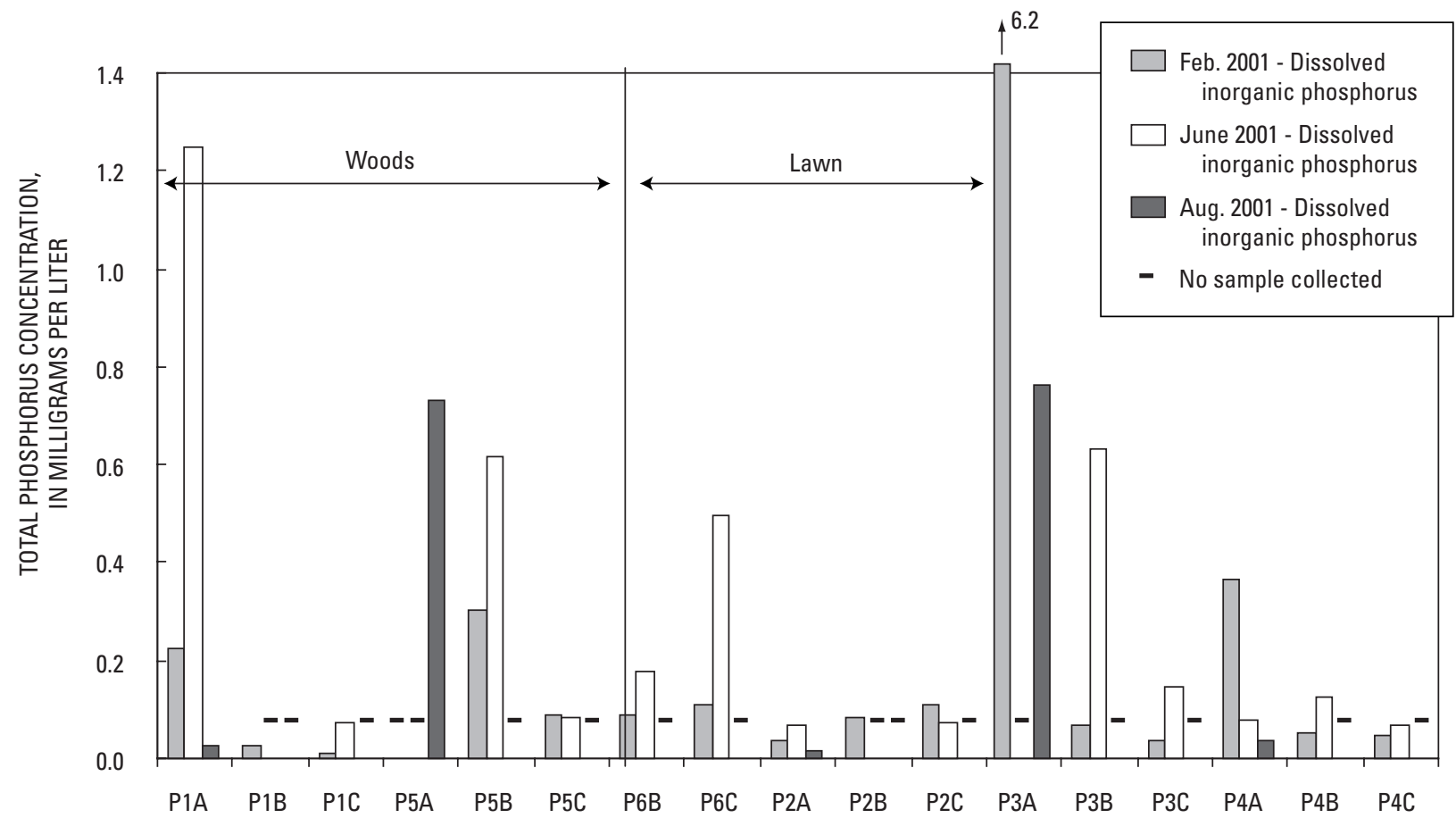

WATER-TABLE WELLS (A) AND PIEZOMETERS (B AND C)

Figure 25b. Total phosphorus concentrations from the shallow (A) and deep (B and C) ground-water systems of the Butternut Lake site, northern Wisconsin. 


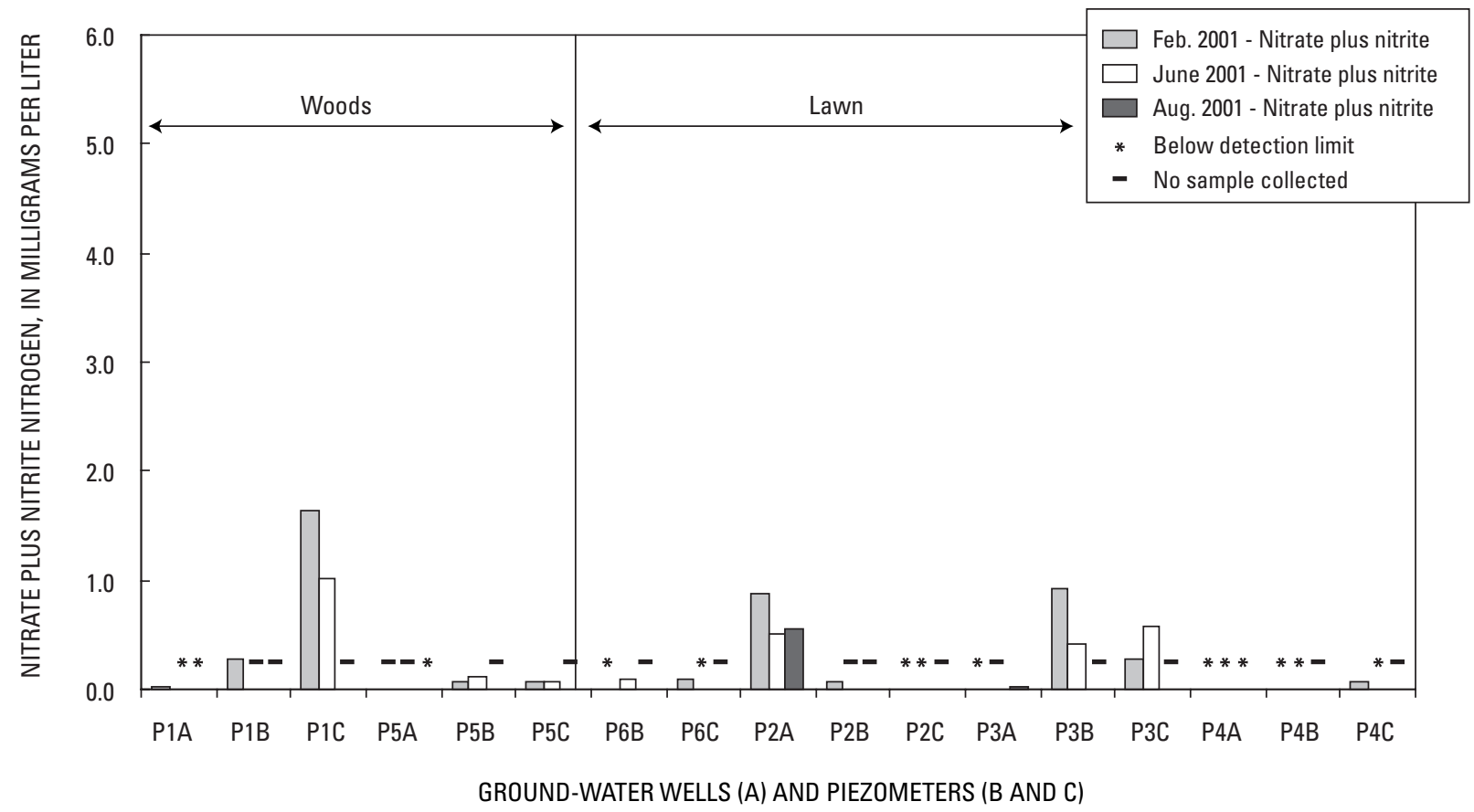

Figure 26a. Nitrate plus nitrite concentrations from the shallow (A) and deep (B and C) ground-water systems of the Butternut Lake site, northern Wisconsin.

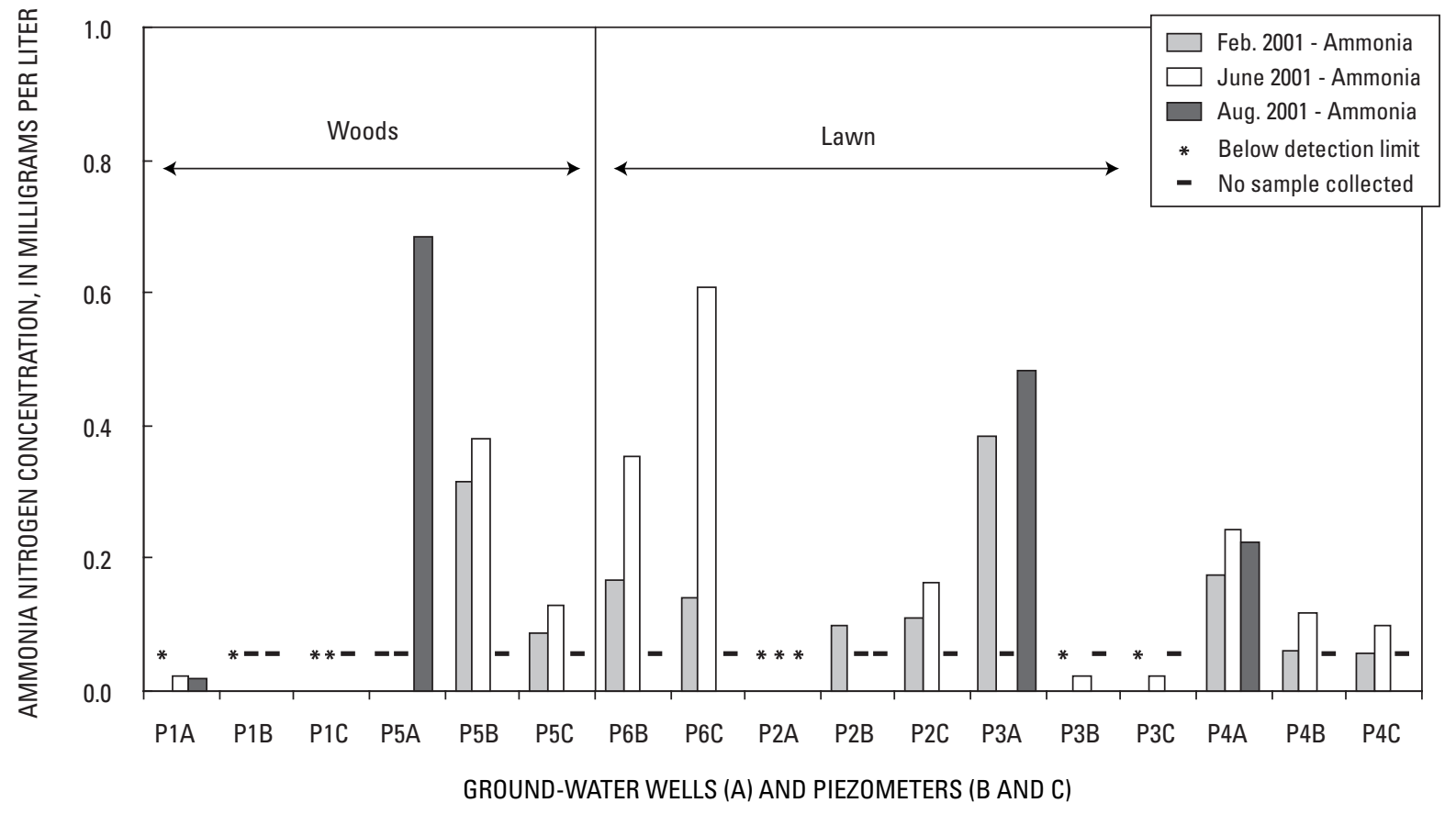

Figure 26b. Ammonia concentrations from the shallow (A) and deep (B and C) ground-water systems of the Butternut Lake site, northern Wisconsin. 
whether lawns or woods contributed more nutrients. These results appear to indicate, therefore, that nutrient export could be reduced by reducing runoff volume.

Annualized yields from each site are presented in figures 28 and 29. Annualized yields were computed by summing the individual yields and normalizing by the 23-month time period. Nutrient yields in pounds per acres per year are in table 12). In almost all cases, the annual nutrient yields from lawns are greater than those from corresponding woods. The only exception to this pattern is the Butternut Lake lower wooded catchment, where yields of ammonia nitrogen, Kjeldahl nitrogen, and dissolved phosphorus and total phosphorus were greater than those from the Butternut Lake lawn catchment.

Nutrient yields from both the lawn and wooded areas generally were less than those found in the previous studies with similar land uses (table 13). These differences may be due to generally larger catchment areas investigated in other studies. This study narrowly focused on small lawn and woods areas; previously reported yields have likely incorporated the added runoff-volume impact of other impervious source areas, such as streets, rooftops, and disturbed soils. A comparative study of residential/ forested land uses (Dennis, 1996) reported greater total phosphorus yields than observed here; although the export ratio (lawn/forest yield value) of 7.4 reported by Dennis (1996) is similar to the 9.0 ratio observed in this study.

\section{Ground Water}

Similar to surface-water yields, ground-water yields can vary, with individual rainfall/snowmelt events sometimes contributing substantial portions to the annual nutrient yield. For example, a study performed in sandy soils in southern Wisconsin demonstrated large temporal changes in nitrate concentrations, which were driven by a complex relation of precipitation infiltration, nutrient loading, vegetation maturity, and residual concentrations from the previous year (Muldoon and others, 1998). Although the investigators noted that large proportions of annual loading were attributed to snowmelt events, the highest loading rates were measured during the fall but were not associated with rainfall events. Clearly, characterizations of the temporal complexity with three sampling periods are inherently uncertain; therefore, the following discussion of yields cannot be considered a well-constrained estimate of ground-water loading to the lakes. However, it is instructive to assess relative contributions from wooded and lawn areas and to provide an approximate estimate of the relative ground-water contributions compared to surface-water contributions.

A comparison of the lawn and wooded-area yields was done for the Lower Ninemile Lake site (fig. 30). Estimates of the ground-water load and yield were computed using the following assumptions. First, the concentrations measured in the shallow ground water at the locations in

Table 12. Summary statistics for annual nutrient yields in runoff from the lawn and woods catchments, northern Wisconsin

[Yields in pounds per acre per year]

\begin{tabular}{|c|c|c|c|c|c|}
\hline \multicolumn{6}{|c|}{ Lawn annual yields, $n=4$} \\
\hline & $\begin{array}{c}\text { Ammonia } \\
\text { nitrogen }\end{array}$ & $\begin{array}{c}\text { Nitrate plus } \\
\text { nitrite nitrogen }\end{array}$ & $\begin{array}{c}\text { Total Kjeldahl } \\
\text { nitrogen }\end{array}$ & $\begin{array}{l}\text { Dissolved } \\
\text { phosphorus }\end{array}$ & Total phosphorus \\
\hline Maximum & $4.35 \times 10^{-2}$ & $5.63 \times 10^{-1}$ & $4.55 \times 10^{-1}$ & $5.80 \times 10^{-2}$ & $8.19 \times 10^{-2}$ \\
\hline Minimum & $1.37 \times 10^{-2}$ & $4.02 \times 10^{-4}$ & $4.56 \times 10^{-2}$ & $3.77 \times 10^{-3}$ & $1.22 \times 10^{-2}$ \\
\hline Mean & $2.5 \times 10^{-2}$ & $1.91 \times 10^{-1}$ & $1.96 \times 10^{-1}$ & $2.156 \times 10^{-2}$ & $3.48 \times 10^{-2}$ \\
\hline Median & $2.15 \times 10^{-2}$ & $1.01 \times 10^{-1}$ & $1.43 \times 10^{-1}$ & $1.22 \times 10^{-2}$ & $2.56 \times 10^{-2}$ \\
\hline \multicolumn{6}{|c|}{ Woods annual yields, $\mathrm{n}=6$} \\
\hline & $\begin{array}{c}\text { Ammonia } \\
\text { nitrogen }\end{array}$ & $\begin{array}{c}\text { Nitrate plus } \\
\text { nitrite nitrogen }\end{array}$ & $\begin{array}{c}\text { Total Kjeldahl } \\
\text { nitrogen }\end{array}$ & $\begin{array}{c}\text { Dissolved } \\
\text { phosphorus }\end{array}$ & Total phosphorus \\
\hline Maximum & $2.16 \times 10^{-2}$ & $1.64 \times 10^{-2}$ & $2.03 \times 10^{-1}$ & $5.20 \times 10^{-3}$ & $2.23 \times 10^{-2}$ \\
\hline Minimum & $4.54 \times 10^{-4}$ & $9.86 \times 10^{-5}$ & $2.92 \times 10^{-3}$ & $3.12 \times 10^{-4}$ & $4.77 \times 10^{-4}$ \\
\hline Mean & $7.61 \times 10^{-3}$ & $3.87 \times 10^{-3}$ & $4.59 \times 10^{-2}$ & $1.51 \times 10^{-3}$ & $5.45 \times 10^{-3}$ \\
\hline Median & $3.86 \times 10^{-3}$ & $4.39 \times 10^{-4}$ & $1.36 \times 10^{-2}$ & $7.80 \times 10^{-4}$ & $2.47 \times 10^{-3}$ \\
\hline
\end{tabular}


Table 13. Comparison of nutrient yields from previous studies throughout the country and from this study in northern Wisconsin [All yields in kilograms per hectare per year; --, not analyzed]

\begin{tabular}{|c|c|c|c|}
\hline Previous study & Land use & $\begin{array}{l}\text { Kjeldahl } \\
\text { nitrogen yield }\end{array}$ & $\begin{array}{c}\text { Total } \\
\text { phosphorus } \\
\text { yield }\end{array}$ \\
\hline King and others, 2001 & Stream draining turf & -- & 0.33 \\
\hline $\begin{array}{l}\text { Kussow, W.R., University of } \\
\text { Wisconsin-Department of Soil } \\
\text { Sciences, written commun., } 2002\end{array}$ & Turf & -- & .40 \\
\hline Dennis, 1986 & Residential & -- & 1.75 \\
\hline Rechow and others, 1980 & Residential & 5.5 & 1.1 \\
\hline Panuska and Lillie, 1995 & Urban & -- & .52 \\
\hline Thomann, 1987 & Urban & 5.0 & 1.0 \\
\hline $\begin{array}{l}\text { Panuska, J.C., Wisconsin Department of } \\
\text { Natural Resources, written commun., } 2002\end{array}$ & Rural residential & -- & .10 \\
\hline Panuska and Lillie, 1995 & Woods & -- & .09 \\
\hline Thomann, 1987 & Woods & 3.0 & .40 \\
\hline Dennis, 1986 & Woods & -- & .19 \\
\hline $\begin{array}{l}\text { Panuska, J.C., Wisconsin Department of } \\
\text { Natural Resources, written commun., } 2002\end{array}$ & Residential woods & -- & .08 \\
\hline Rechhow and others, 1980 & Residential woods & 2.46 & .20 \\
\hline This study & Lawn & 0.16 & 0.025 \\
\hline This study & Woods & 0.015 & 0.003 \\
\hline
\end{tabular}

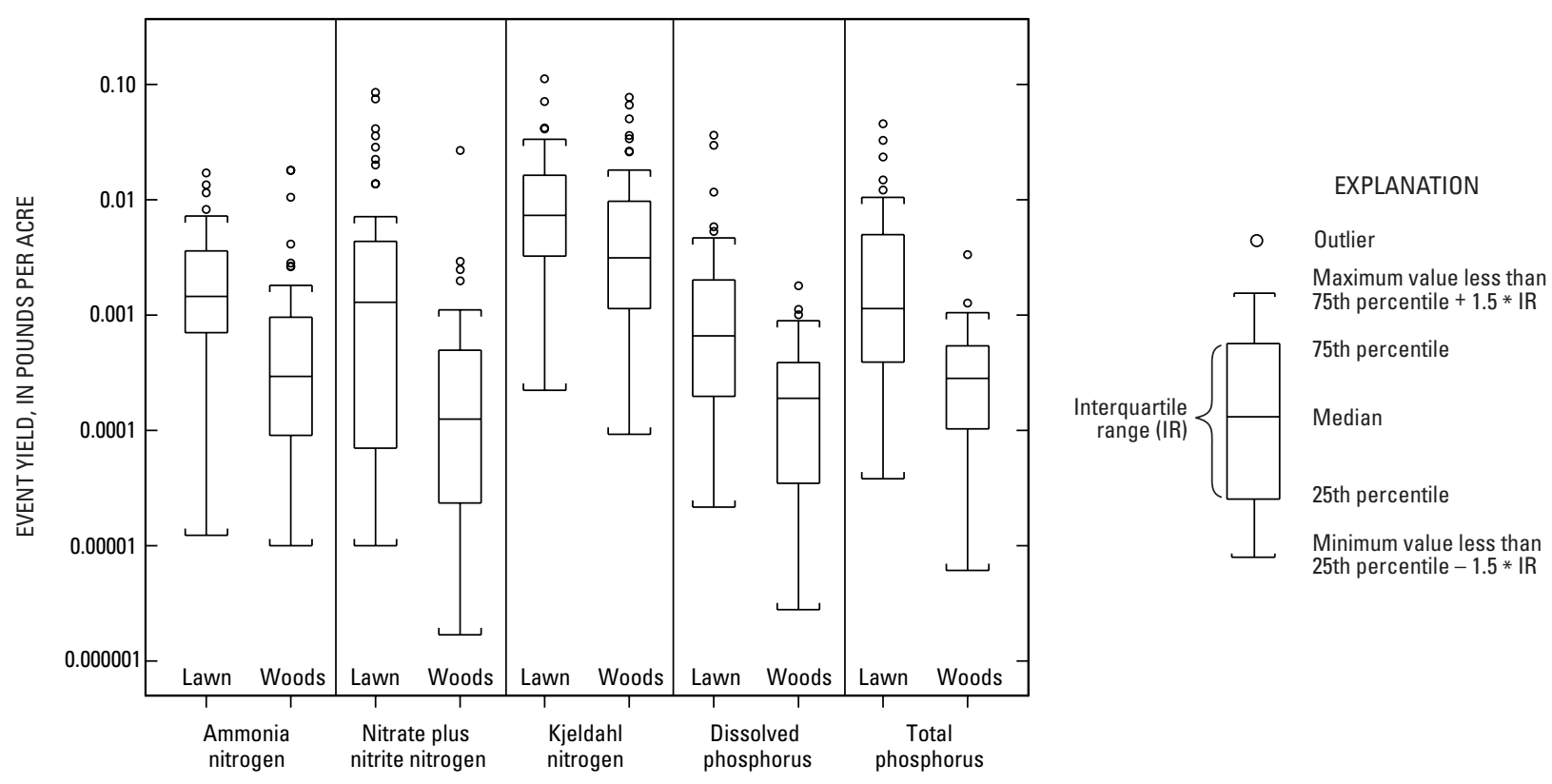

Figure 27. Event nutrient yields of surface runoff for lawn and wooded catchments, northern Wisconsin. 

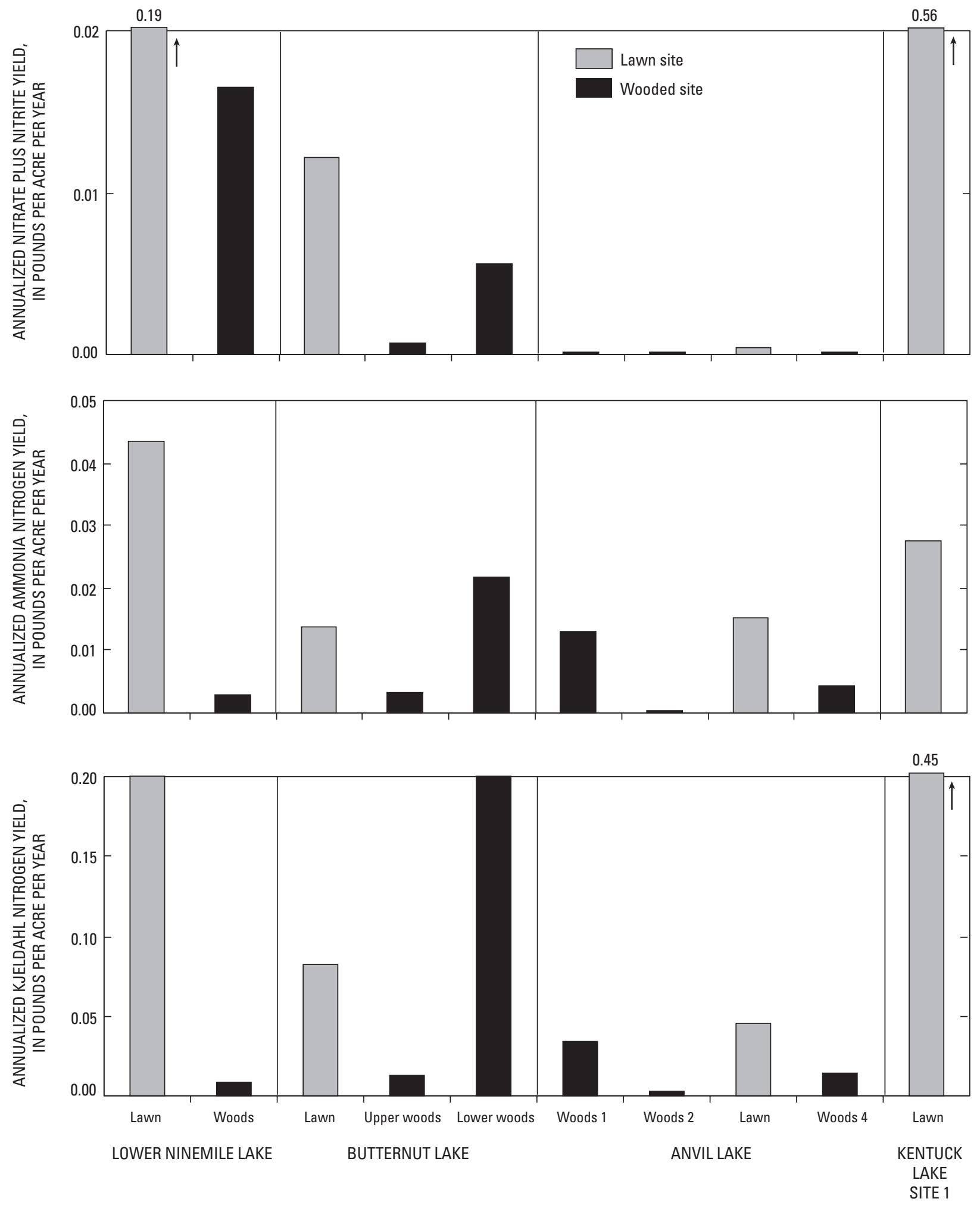

Figure 28. Nitrate plus nitrite, ammonia, and Kjeldahl nitrogen annual surface-runoff yield at lawn and wooded catchments, northern Wisconsin. 

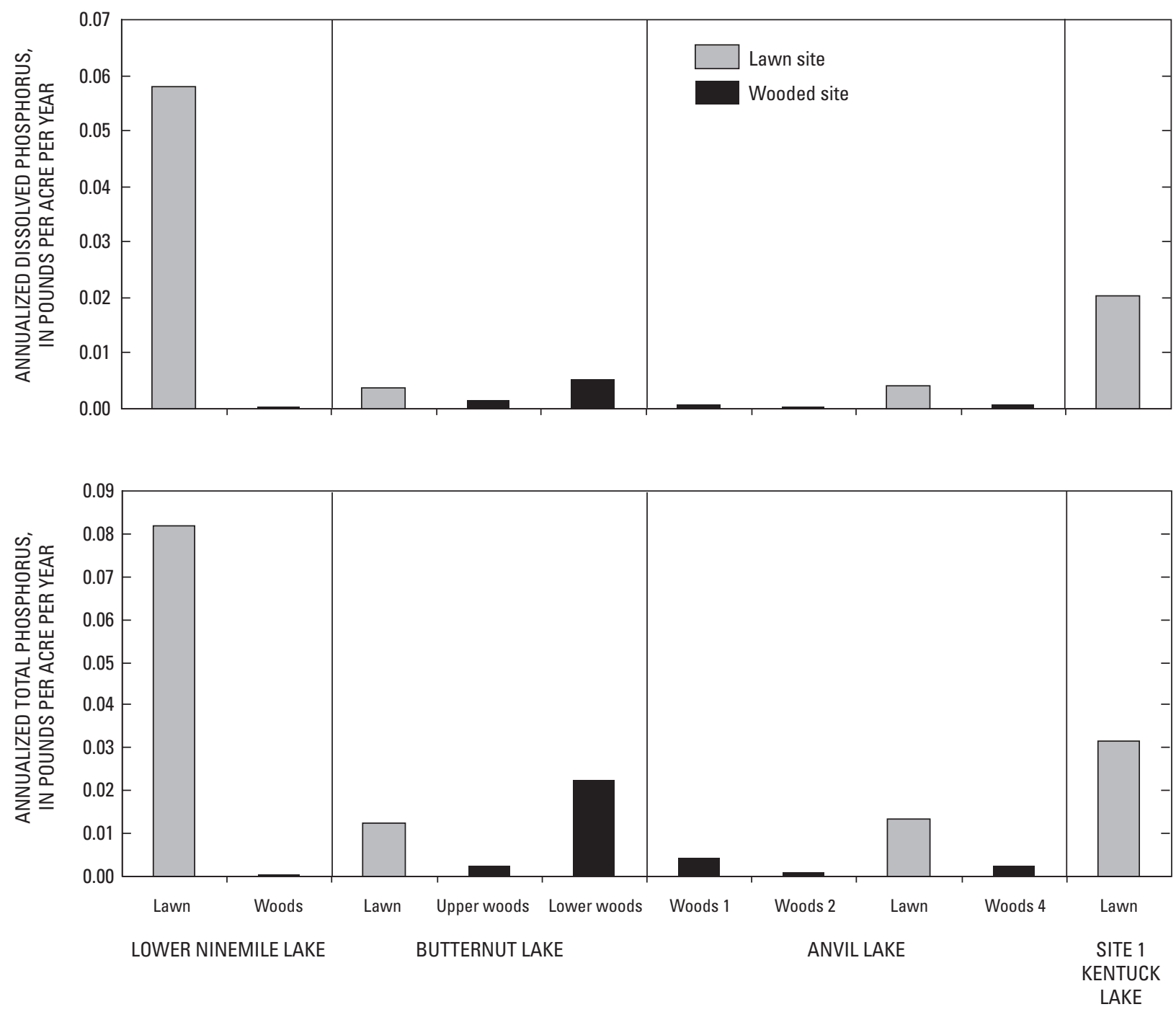

Figure 29. Dissolved and total phosphorus annual surface-runoff yield at lawn and wooded catchments, northern Wisconsin.

the lawn and woods characterized the entire associated lawn or woods catchment. Second, a median concentration of the three sampling periods was representative of the entire year. Third, the surface area that supplied the ground-water recharge did not change over time. Last, the actual ground-water-recharge rate was bracketed by the low, intermediate, and high recharge rates used to calculate the volume of ground-water recharge listed in table 8. Results derived from the use of these assumptions clearly indicate that ground water in the catchment can be a major pathway for nutrient transport (fig. 30). Because of the small sample size, a statistical determination of significance could not be done as was done for surfacerunoff nutrient yields, but the results indicate that groundwater yields of nitrate plus nitrite and total phosphorus from lawns are approximately 3 to 4 times those from the woods. No obvious difference was found between groundwater yields from the lawn or woods for dissolved inorganic phosphorus (fig. 30).

Because ground-water quality measured in the wells at the Butternut Lake site was varied over time and space and because characterization of the ground-water-flow system was made difficult by the presence of the clay lens, considerable uncertainty is associated with loads to Butternut Lake. Obtaining accurate estimates of nutrient yields would require additional characterization of the ground-water-flow system and the spatial and temporal nutrient history in the shallow ground water. These inherent uncertainties notwithstanding, it appears that the findings from the Lower Ninemile Lake site also may apply to the parts of the Butternut Lake site given the differences in concentrations measured in shallow ground water 


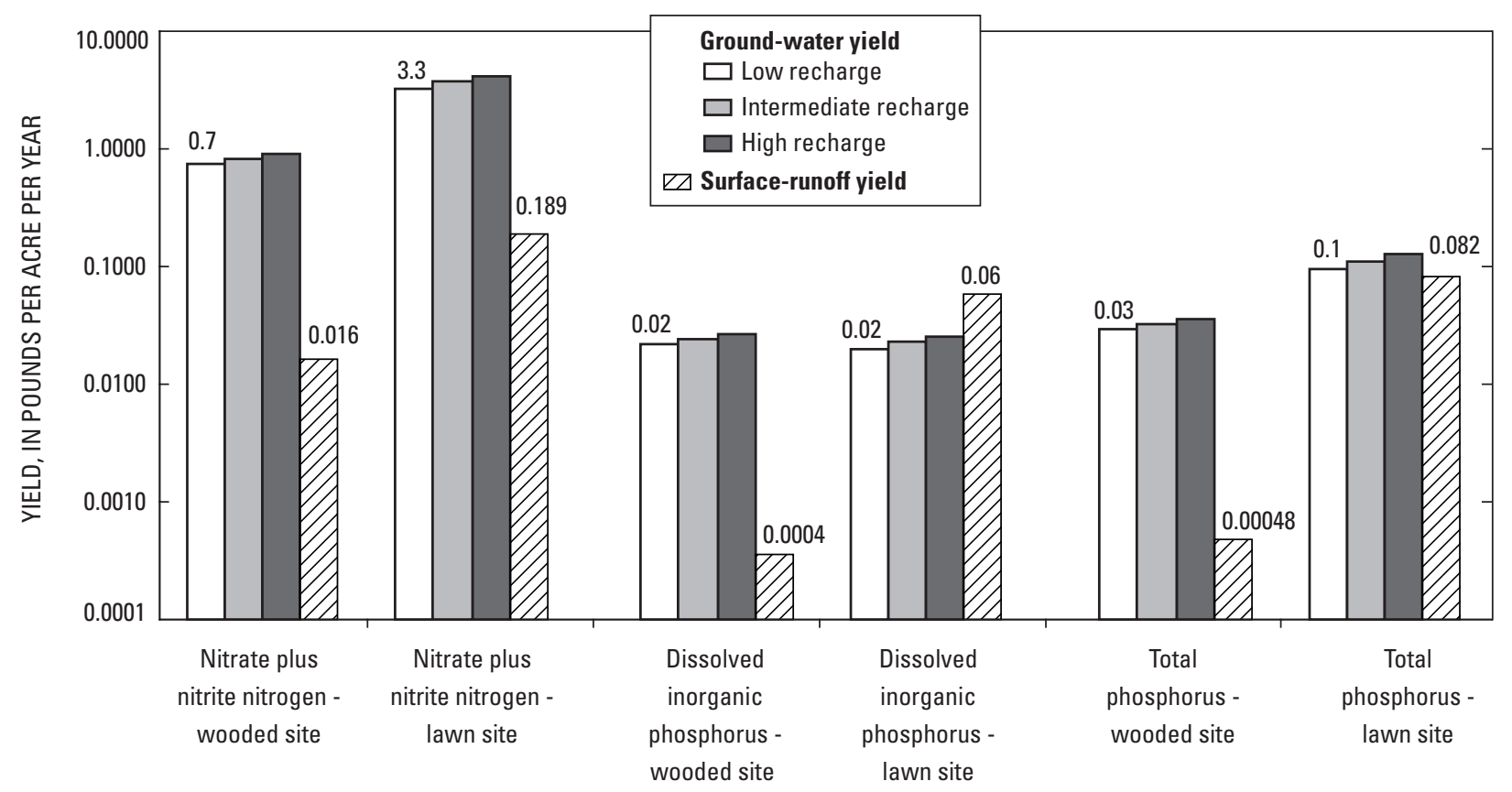

Figure 30. Comparison of surface runoff and ground-water yields at the Lower Ninemile Lake site, northern Wisconsin.

beneath the lawn and the woods. Because the ground water immediately under the P3 lawn location contains higher nutrient concentrations than that under the woods, nutrient yields from lawn areas might be expected to be greater than yields from undeveloped woods areas. However, the Butternut Lake site results also indicate that the location and type of lawn site can affect ground-water nutrient yields. Given the results from the P3 well nest, lawn sites where the slope ends at the lakeshore are expected to have a large adverse effect on the lake. Results from the P4 lawn location indicate that an intervening flat or buffer area may reduce the effects of the higher runoff and also may allow uptake of the high levels of nutrients (especially phosphorus) infiltrated into the shallow ground water. However, this indication requires additional work to assess transferability to other lawn settings and ground-water-flow systems.

\section{Future Work Needed For Calculating Loads to Lakes}

The results presented in this report characterize the near-lake loads at catchments within the four lake basins. However, additional information is needed to extrapolate these results to the larger lake and (or) riparian system. Capture zones of the Lower Ninemile Lake and Butternut Lake systems are shown in figure 13b. Because capture zones reflect all the areas that discharge ground water to the lakes and the tributary systems to the lakes, estimates of the land use in these zones and associated nutrient loads and transformations would have to be obtained in order to estimate total lake loads and the effects of land-use change on the lake loads. In addition, nutrient transformations and sinks in the watershed, along with those within tributary streams or headwater lakes, also may have to be accounted for.

\section{Transferability of Ground-Water Results}

Ideally, the study results described here would be widely applicable to many other sites and settings. However, it is unlikely that a ground-water study of two developed and undeveloped catchments can encompass the natural variability of environmental settings and flow systems. This observation notwithstanding, we believe that some generalities are applicable to many sites in northern Wisconsin.

First, dammed flowage lakes can be expected to have a simpler geology and flow system than natural ice-block (kettle) lakes. A great deal of recreational development has occurred around lakes in northern Wisconsin; therefore, the subsurface information from water wells may be misleading in terms of regional subsurface geologic conditions (John Attig, Wisconsin Geological and Natural History 
Survey, written commun., 2002). Most of these wells are near lakes and tend to reflect the local complex stratigraphy resulting from the demise of an ice block and are not representative of the much more uniform sandy sediment that dominates a short distance from most lakes in the extensive outwash plains. Therefore, although ice-block lakes are expected to have more complex near-lake geology and associated site-scale flow systems, the regional flow system is expected to be more similar to the flow system observed at the Lower Ninemile Lake site.

It should be noted that not all ice-block lakes are bordered by complex geology (John Attig, Wisconsin Geological and Natural History Survey, written commun., 2002). The protruding ice block may not contain appreciable debris, with little sediment available for deposition. Moreover, if the ice block is deeply buried rather than protruding, no material is available to collapse on the fine-grained sediments of the ice-block depression. Attig (1985) suggests that the topography near ice-block lakes can be useful for identifying the presence of debris-rich protruding ice blocks; that is, hummocky terrain adjacent to the southern and western sides of lakes indicates the presence of a protruding debris-rich ice block. These areas would be expected to have the near-lake silt and clay layers and more complex lake-ground water interaction, such as that observed by Kenoyer and Anderson (1989) in western Vilas County.

Shallow ground water beneath lawn catchments at the Lower Ninemile Lake site had higher and more variable nutrient concentrations than did ground water underneath the adjacent undeveloped wooded catchments. At two lawn areas at the Butternut Lake site, however, ground-water quality was similar to ground-water quality underlying the undeveloped woods. On the basis of concentrations and yields, the study results indicate undeveloped wooded areas have less effect on the shallow ground-water nutrient levels than do lawn areas. Although more work is needed, the study results indicate that choosing appropriate landscape position for lawns (such as slopes that do not terminate at the lake and areas with flat intervening or buffer areas between lawn and lake) can help reduce the adverse effect of the lawn on the shallow ground water and ultimately the lake.

\section{Summary}

With recent, rapid shoreline development in northern Wisconsin have come concerns that the increased development may impair lake-water quality. In order to assess the effects of development on lakes, the U.S. Geological Survey, in cooperation with the Wisconsin Department of Natural Resources, quantified the surface runoff and ground-water inputs from 4 catchments in northern Wisconsin.

Surface runoff and ground-water volumes and waterquality samples were collected over a 23-month period (November 1999 - September 2001) from lawn/wooded paired catchments in nearshore areas of four lakes in northern Wisconsin. In general, the surface-runoff volumes from the lawn catchments were an order of magnitude greater than those at the respective paired wooded catchments. Because nutrient loads were simply a product of the water volumes and concentrations, the increased water volumes from the lawn sites resulted in greater nutrient loads and subsequent annual yields.

No clear pattern was found in the surface-water nutrient-concentration data in comparisons of nutrient concentrations among catchments. The nonparametric Wilcoxon test was used to determine whether the difference in the median concentrations were statistically significant. Some of the median nutrient concentrations from lawns were significantly greater than those at paired woods catchments. When a composite of all lawn samples across sites was compared to a composite of all woods samples across sites, the median nutrient concentrations from woods were greater than those from the lawns, except for nitrate plus nitrite nitrogen.

The ground-water system was monitored with wells, piezometers, thermocouples, and soil-moisture probes. At the Lower Ninemile Lake site, (sloped) lawn soils were warmer and drier than soils in the woods. At the Butternut Lake site (lawn flat, woods sloped), the lawn generally was wetter, reflecting runoff from the adjacent slope. Groundwater levels varied appreciably as a result of manipulations of lake stage (Lower Ninemile Lake site) and complex geology inherent to kettle lakes (Anvil Lake, Site 1 Kentuck Lake, and Butternut Lake sites). Ground-water-flow modeling of the site showed that much of the ground water delivered to the lake resulted from distant areas that did not contribute runoff directly to the lake. A complete study of lake loads, therefore, would have to include near and distant areas in the ground-water contributing area of the lake.

The wells and piezometers were sampled for chemical analysis three times during the study period. At the Lower Ninemile Lake and Butternut Lake sites, the shallow ground-water chemistry varied appreciably over time in the lawn samples. This variation was not as evident in the woods or the upgradient well. 
Although concentration data can give insight into short-term processes and transport mechanisms affecting lake water quality, the effects of land uses on water quality ultimately will be a result of yields of constituents being transported to the lake. Results of yield computations indicate that median nutrient yields from lawns always were greater than those from woods. The median yields from lawns were an order of magnitude greater for ammonia nitrogen, nitrate plus nitrite, and total phosphorus than those yields from woods. Runoff volumes were the most important factor in determining whether lawns or woods contributed more nutrients to lakes.

The ground-water system may be an important pathway for nutrient transport; therefore, yields of constituents to ground water from lawns and wooded areas were calculated for the Lower Ninemile Lake site. Although there is uncertainty concerning whether results from three ground-water sampling periods represent actual conditions, it appears that lawns are approximately 3 to 4 times greater contributors of nitrate plus nitrite nitrogen and total phosphorus than woods when yields were computed by means of median concentrations and a range of recharge rates. No obvious difference was indicated between lawns and woods for dissolved inorganic phosphorus.

This study characterizes the nearshore lake loads at two locations within the respective basins. Additional information is needed to extrapolate these results to a large lake and (or) riparian system. Ideally, these study results would be widely applicable to many other sites and settings. The ground water beneath two lawn catchments had nutrient concentrations greater and more variable than those in ground water beneath adjacent undeveloped (wooded) catchments. This study indicates that undeveloped wooded areas have less effect on shallow groundwater concentrations than do lawn areas. Also, surfacerunoff yields from the wooded site would have less effect on the lake water quality than the surface-runoff yields from the lawn sites. Choosing the appropriate landscape position when selecting lawn location (slopes that do not terminate at the lake, and areas with intervening flat or buffer zones between lawn and lake) can help reduce the adverse effect of the lawn on the shallow ground-water quality and, ultimately, the lake water-quality.

\section{References}

Attig, J.W., 1985, Pleistocene geology of Vilas County: Wisconsin Geological and Natural History Survey Information Circular 50, $32 \mathrm{p}$.
Bannerman, R.T., Legg, A.D., and Greb, S.R., 1996, Quality of Wisconsin stormwater, 1989-1994: U.S. Geological Survey Open-File Report 96-458, 26 p.

Barten, J.M., and Jahnke, D., 1997, Suburban lawn runoff water quality in the Twin Cities Metropolitan Area, 1996 and 1997: Maple Plain, Minn., Internal report to Suburban Hennepin Regional Park District, 17 p.

Cole, J.T., Baird, J.H., and Cole, J.C., 1997, Influence of buffers on pesticide and nutrient runoff from Bermuda grass turf: Journal of Environmental Quality, v. 26, no. 26 , p. 1589-1598.

Conover, W.J., 1980, Practical nonparametric statistics ( $2 \mathrm{~d}$ ed.): New York, New York, John Wiley and Sons, 493 p.

Dennis, J. 1986, Phosphorus export from a low-density residential watershed and an adjacent forested watershed, in Fifth Annual Conference and International Symposium on Applied Lake and Watershed Management, 1986; Proceedings of the North American Lake Management Society, Lake Geneva, Wisconsin, Lakes and Reservoir Management, v. 2, p. 401-407.

Garn, H.S., 2002, Effects of lawn fertilizer on nutrient concentration in runoff from lakeshore lawns, Lauderdale Lake, Wisconsin: U.S. Geological Survey Water-Resources Investigations Report 02-4130, 6 p.

Haitjema, H.M., 1995, Analytic element modeling of groundwater flow: San Diego, Calif., Academic Press, 394 p.

Haitjema, H.M., Kelson, V.A., and de Lange, W., 2001, Selecting MODFLOW cell sizes for accurate flow fields: Ground Water, v. 39, no. 6, p. 931-938.

Hill, M.C., 1992, A computer program (MODFLOWP) for estimating parameters of a transient, three-dimensional, ground-water flow model using nonlinear regression: U.S. Geological Survey Open-File Report 91-484, $358 \mathrm{p}$.

1998, Methods and guidelines for effective model calibration: U.S. Geological Survey Water-Resources Investigations Report 98-4005, 90 p.

Hunt, R.J., and Krohelski, J.T., 1996, The application of an analytic element model to investigate groundwater-lake interactions at Pretty Lake, Wisconsin: Journal of Lake and Reservoir Management, v. 12, no. 4, p. 487-495.

Hunt, R.J., Anderson, M.P., and Kelson, V.A., 1998, Improving a complex finite-difference ground water flow model through the use of an analytic element screening model: Ground Water, v. 36, no. 6, p. 1011-1017. 
Hunt, R.J., Lin, Y., Krohelski, J.T., and Juckem, P.F., 2000 , Simulation of the shallow hydrologic system in the vicinity of Middle Genesee Lake, Wisconsin, using analytic elements and parameter estimation: U.S. Geological Survey Water-Resources Investigations Report 00-4136, 16 p.

Hunt, R.J., and Steuer, J.J., 2000, Simulation of the recharge area for Frederick Springs, Dane County, Wisconsin: U.S. Geological Survey Water-Resources Investigations Report 00-4172, 33 p.

Hunt, R.J., Haitjema, H.M., Krohelski, J.T., and Feinstein, D.T., 2003, Simulating lake-ground water interactions: MODFLOW and analytic element approaches: Ground Water, v. 41, no. 2, p. 227-237.

Kelson, V.A., Hunt, R.J., and Haitjema, H.M., 2002, Improving a regional model using reduced complexity and parameter estimation: Ground Water, v. 40, no. 2, p. $138-149$.

Kenoyer, G., and Anderson, M.P., 1989, Groundwater's dynamic role in regulating acidity and chemistry in a precipitation-dominated lake: Journal of Hydrology, v. 109 , p. 287-306.

King, K.W., Harmel R.D., Torbert, H.A., and Balogh, J.C., 2001, Impact of a turfgrass system on nutrient loadings to surface water: Journal of American Water Resources Association, v. 37, no. 3, p. 629-640.

Legg, A.D., Bannerman, R.T., and Panuska, J.C., 1996, Variation in the relation of rainfall to runoff from residential lawns in Madison, Wisconsin, July and August 1995: U.S. Geological Survey Water-Resources Investigations Report 96-4194, 11 p.

Mitchell-Bruker, S., and Haitjema, H., 1996, Modeling steady state conjunctive groundwater and surface water flow with analytic elements: Water Resources Research, v. 32 , no. 9 , p. 2725-2732.

Muldoon, M.A., Madison, F.W., and Birl, L., 1998, Variability of nitrate loading and determination of monitoring frequency for a shallow sandy aquifer, Arena, Wisconsin: Wisconsin Geological and Natural History Survey Open File Report, WOFR 1998-9, 26 p., and 1 diskette.

National Oceanic and Atmospheric Administration, 2000, Climatological data, annual summary, Wisconsin: v. 105 , no. 13,27 p.

Panuska, J.C., and Lillie, R.A., 1995, Phosphorus loadings from Wisconsin watersheds-Recommended phosphorus export coefficients for agricultural and forested watersheds: Wisconsin Department of Natural Resources Research Findings, no. 38, 8 p.
Pitt, R., and Voorhees, J., 1993, Source loading and management model (SLAMM) seminar publication: National Conference on urban runoff managementEnhancing urban watershed management at the local, county, and state levels, March 30- April 2, 1993, Center for Environmental Research Information: Cincinnati, Ohio, U.S. Environmental Protection Agency EPA/625/ R-95/003, p. 225-243.

Poeter, E.P., and Hill, M.C., 1997, Inverse models-A necessary next step in ground-water modeling: Ground Water, v. 35, no. 2, p. 250-260.

1998, Documentation of UCODE, a computer code for universal inverse modeling: U.S. Geological Survey Water-Resources Investigations Report 98-4080, 116 p.

Rechow, K.H., Beaulac, M.N., and Simpson, J.T., 1980, Modeling phosphorus loading and lake response under uncertainty - A manual and compilation of export coefficients: Washington, D.C., U.S. Environmental Protection Agency Office of Water Regulations and Standards, Criteria and Standards Division, EPA 440/5-80-011, $214 \mathrm{p}$.

Rosenberry, D.O., 1990, Effect of sensor error on interpretation of long-term water-level data: Ground Water, v. 28 , no. 6 , p. 927-936.

Simpkins, W.W., McCartney, M.C., and Mickelson, D.M., 1987, Pleistocene geology of Forest County: Wisconsin Geological and Natural History Survey Information Circular 61, $22 \mathrm{p}$.

Strack, O.D.L., 1989, Groundwater mechanics: Englewood Cliffs, N.J., Prentice-Hall, 732 p.

Thomann, R.V., 1987, Principles of surface water quality modeling and control: New York, Harper and Row, $644 \mathrm{p}$.

U.S. Environmental Protection Agency, 1983, Results of the National Urban Runoff Program: Washington D.C., U.S. Environmental Protection Agency Water Planning Division, NTIS Document PB 84-185552 (various pagination).

Waschbusch, R.J., Selbig, W.R., and Bannerman, R.T., 1999, Sources of phosphorus in stormwater and street dirt from two urban residential basins in Madison, Wisconsin, 1994-95: U.S. Geological Survey WaterResources Investigations Report 99-4021, 47 p.

Wisconsin Department of Natural Resources, 2000, Wisconsin Administrative Code, Environmental Protection, Chapter NR115, no. 532.

Wisconsin Laboratory of Hygiene, 1992, Manual of analytical methods of quality assurance: Madison, Wis., University of Wisconsin, 330 p. 


\section{Appendixes}


Appendix 1. Description of soil cores from the Lower Ninemile Lake lawn and woods sites, and the site 1 Kentuck Lawn lawn site

A total of five cores were collected at Lower Ninemile Lake, Butternut Lake, and Kentuck Lake site 1 by means of a Geoprobe sampler equipment with a large-bore-probe drive system. Core diameter was 1-in and core lengths generally were 8 -ft. Cores at individual sites were collected in both woods and lawns. On a regional scale, the surficial deposits in the vicinity of these lakes are similar. On a site-specific scale, a major difference among the sites was the presence or absence of finegrained material. For example, lacustrine clay was found at depth at Butternut Lake site and at the surface at the Kentuck Lake site. Even at the same lake site, variation in the fine-grained material was found. For example, a 3-ft mantle of silt over sand was found at the Butternut Lake site in the wooded area but was absent from the site on the lawn. Sand and gravel was found at all of the lakes sites. 
Appendix 1. Soil core descriptions for selected wells in Vilas, Oneida, and Forest Counties, Wisconsin

\begin{tabular}{|c|c|c|c|}
\hline Location & Well & $\begin{array}{c}\text { Interval } \\
\text { (feet below } \\
\text { level surface) }\end{array}$ & Core description \\
\hline \multicolumn{4}{|l|}{ Butternut Lake (Forest County) } \\
\hline \multirow[t]{7}{*}{ (woods) } & $\mathrm{P} 1 \mathrm{~A}$ & $0-0.5$ & Silt loam with organic matter \\
\hline & & $0.5-1$ & Silt loam \\
\hline & & $1-5$ & Gravelly sand \\
\hline & & $5-6$ & Clean fine sand \\
\hline & & $6-8$ & Thin lenses ( $<1$ inch) of fine sand and silty sand \\
\hline & & $8-10$ & Silty clay \\
\hline & & $10-12$ & Core empty (probably loose sand) \\
\hline \multirow[t]{3}{*}{ (lawn) } & $\mathrm{P} 2 \mathrm{~A}$ & $0-0.5$ & Silt loam with organic matter \\
\hline & & $0.5-1$ & Silt loam \\
\hline & & $1-8$ & Gravelly fine sand \\
\hline \multicolumn{4}{|c|}{ Kentuck Lake (Vilas and Forest Counties) } \\
\hline Site 1 & $\mathrm{~K} 1 \mathrm{~A}$ & $0-1$ & Clay with organic matter \\
\hline \multirow[t]{4}{*}{ (lawn) } & & $1-5$ & Clay \\
\hline & & $5-6$ & Clay with sand lenses \\
\hline & & $6-7$ & Clean sand \\
\hline & & $7-8$ & Gravelly sand \\
\hline \multicolumn{4}{|c|}{ Lower Ninemile Lake (Oneida and Vilas Counties) } \\
\hline \multirow[t]{3}{*}{ (woods) } & G1A & $0-3$ & Silt \\
\hline & & $3-5$ & Clean fine sand \\
\hline & & $5-8$ & Clean medium sand \\
\hline \multirow[t]{4}{*}{ (lawn) } & G7A & $0-1$ & Silty fine sand \\
\hline & & $1-4$ & Clean fine sand \\
\hline & & $4-7$ & Gravelly medium sand \\
\hline & & $7-8$ & Clean fine sand \\
\hline
\end{tabular}




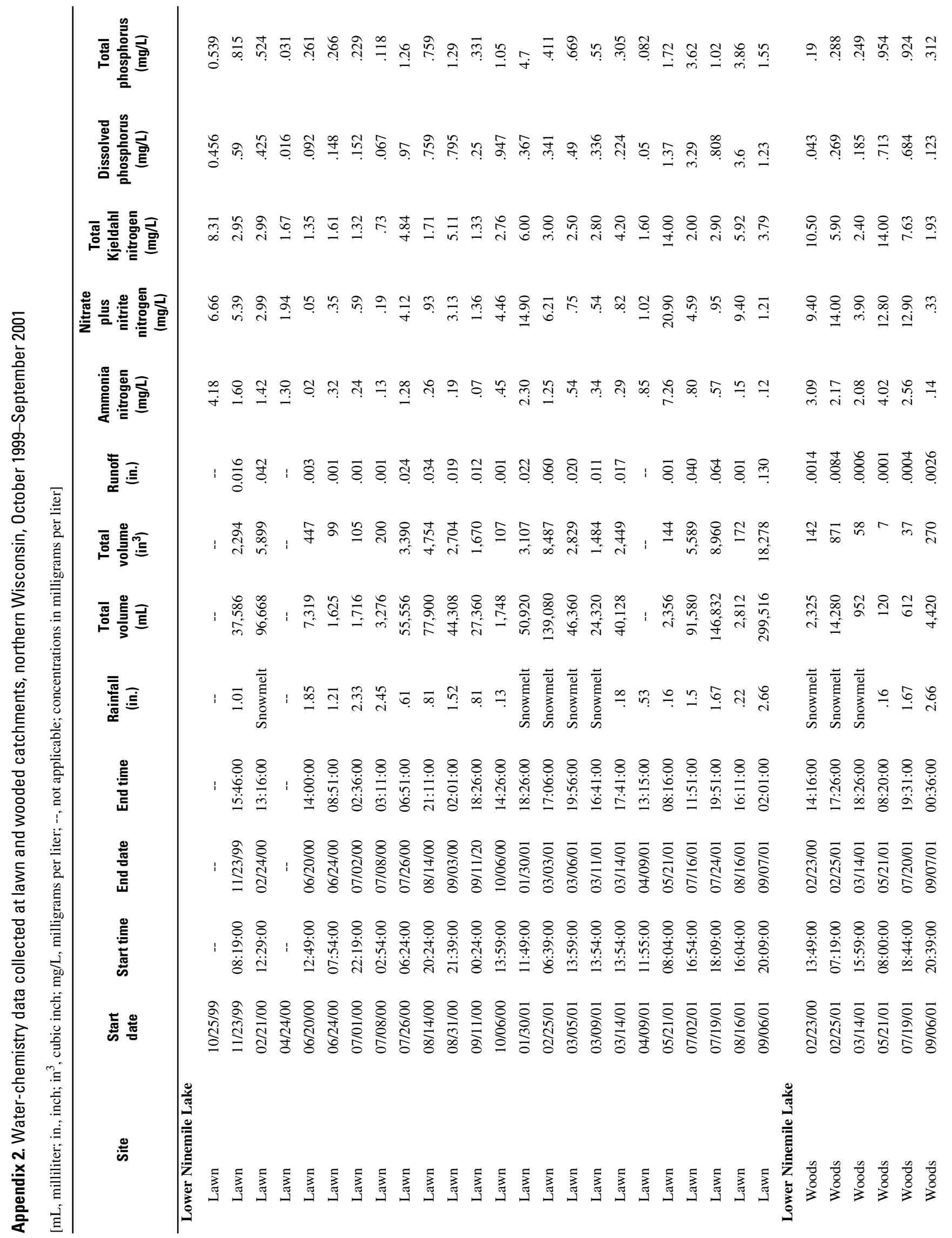




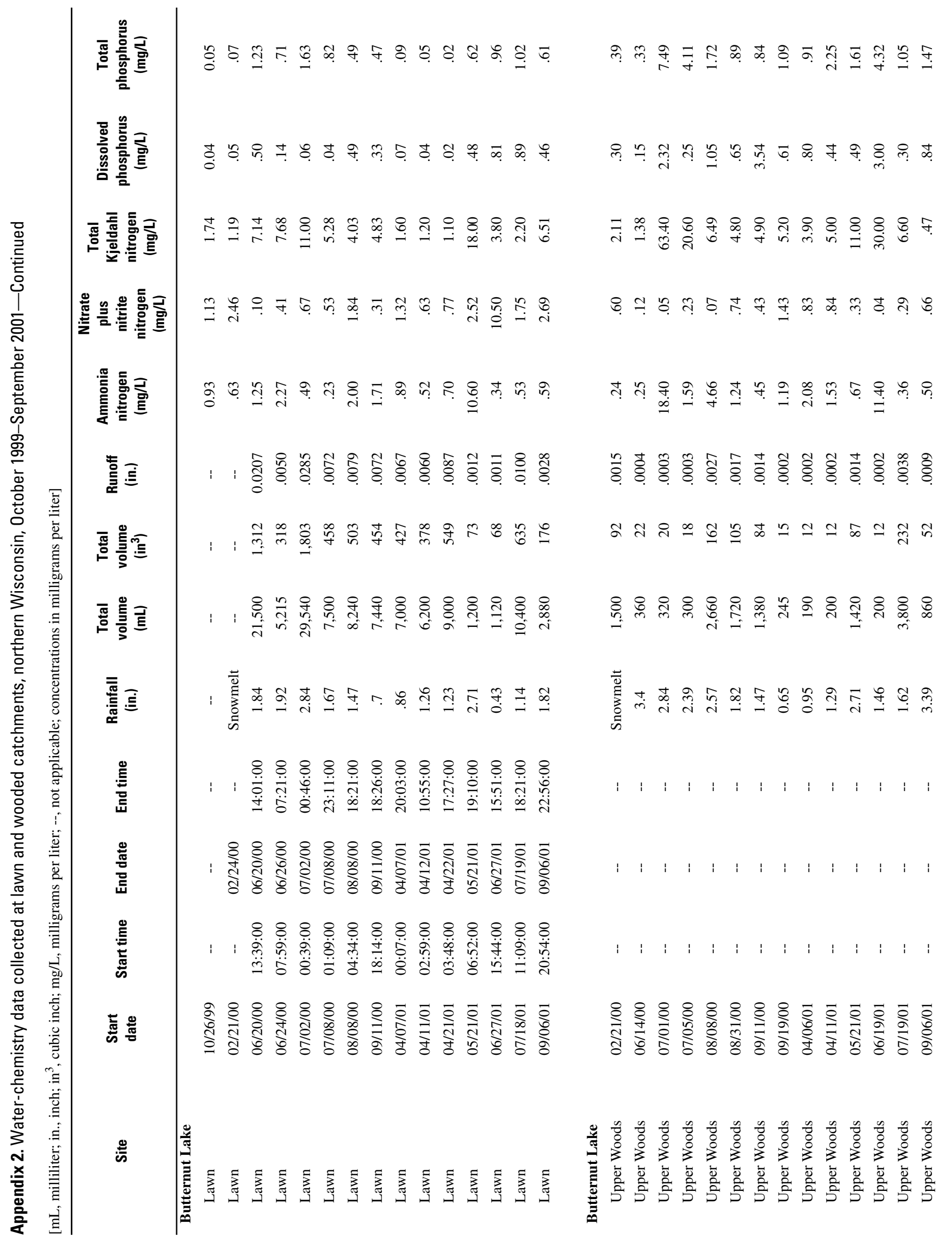




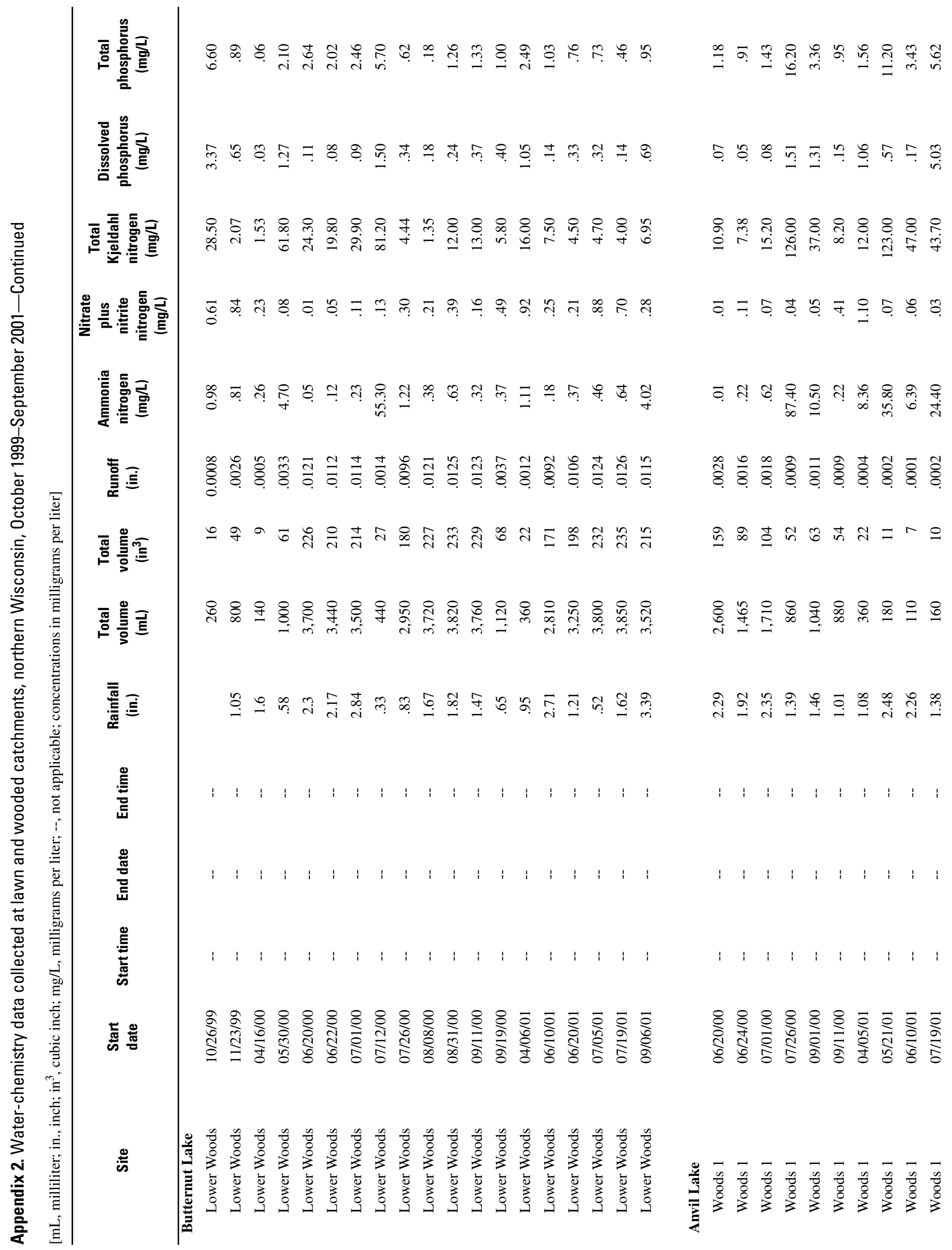




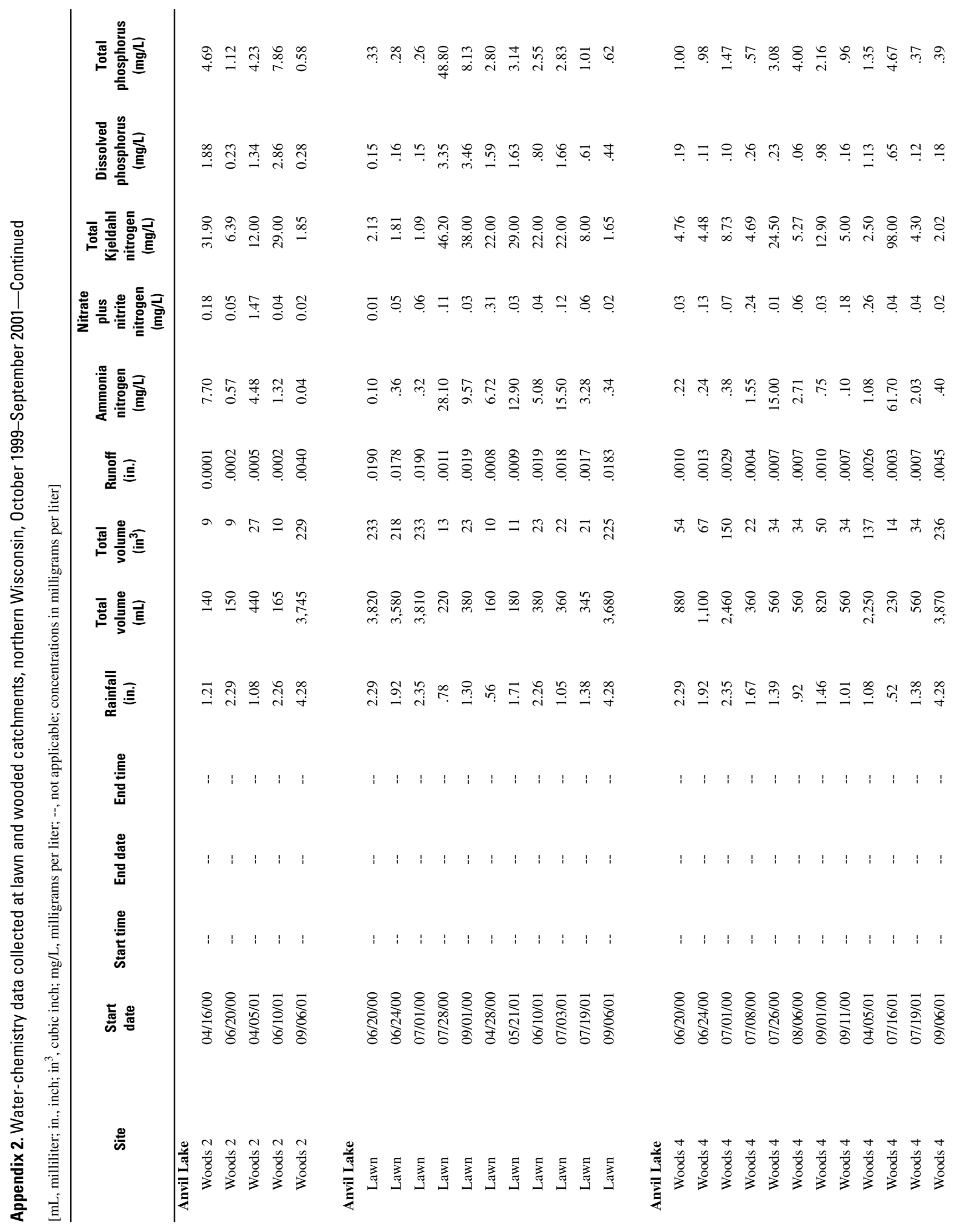




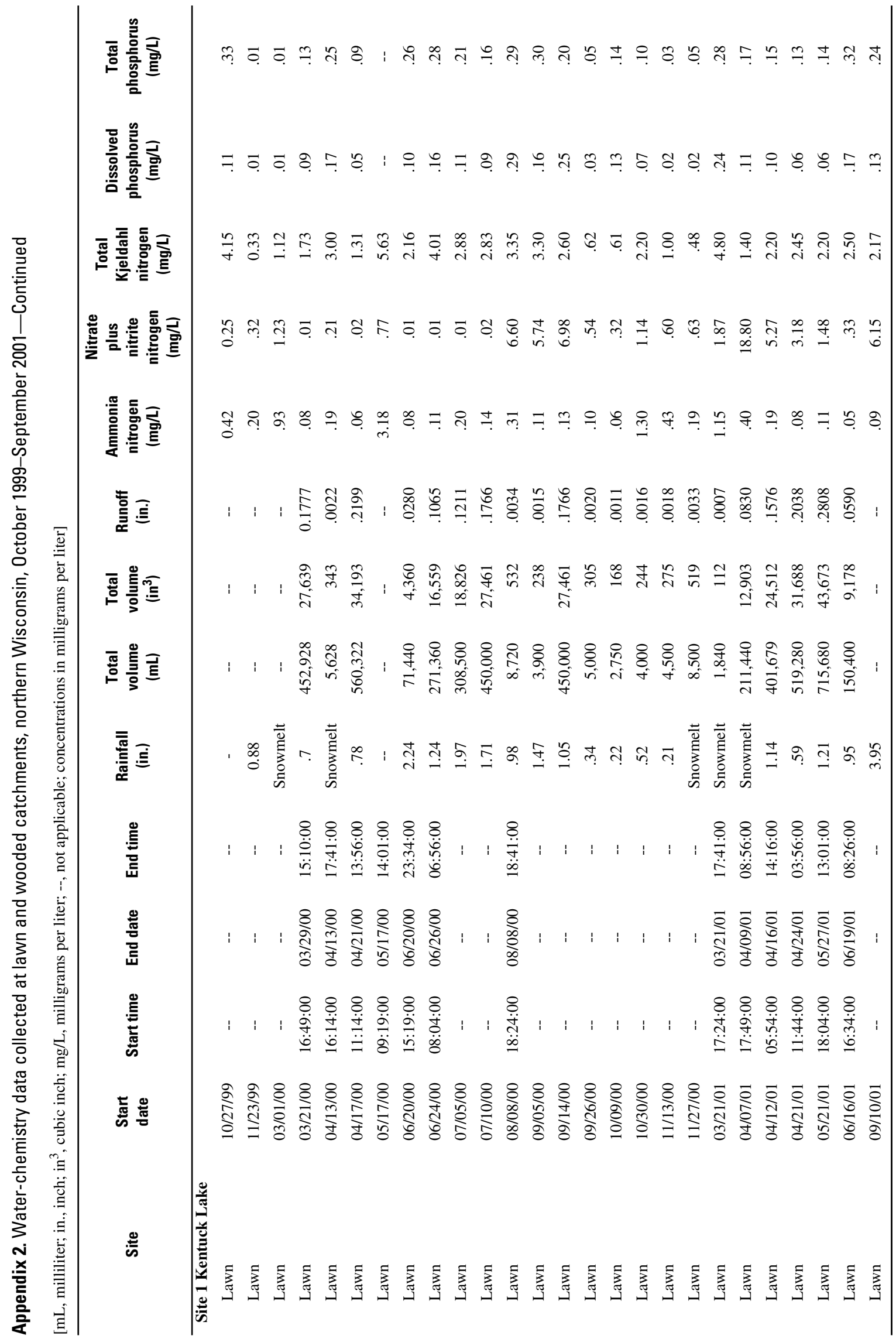




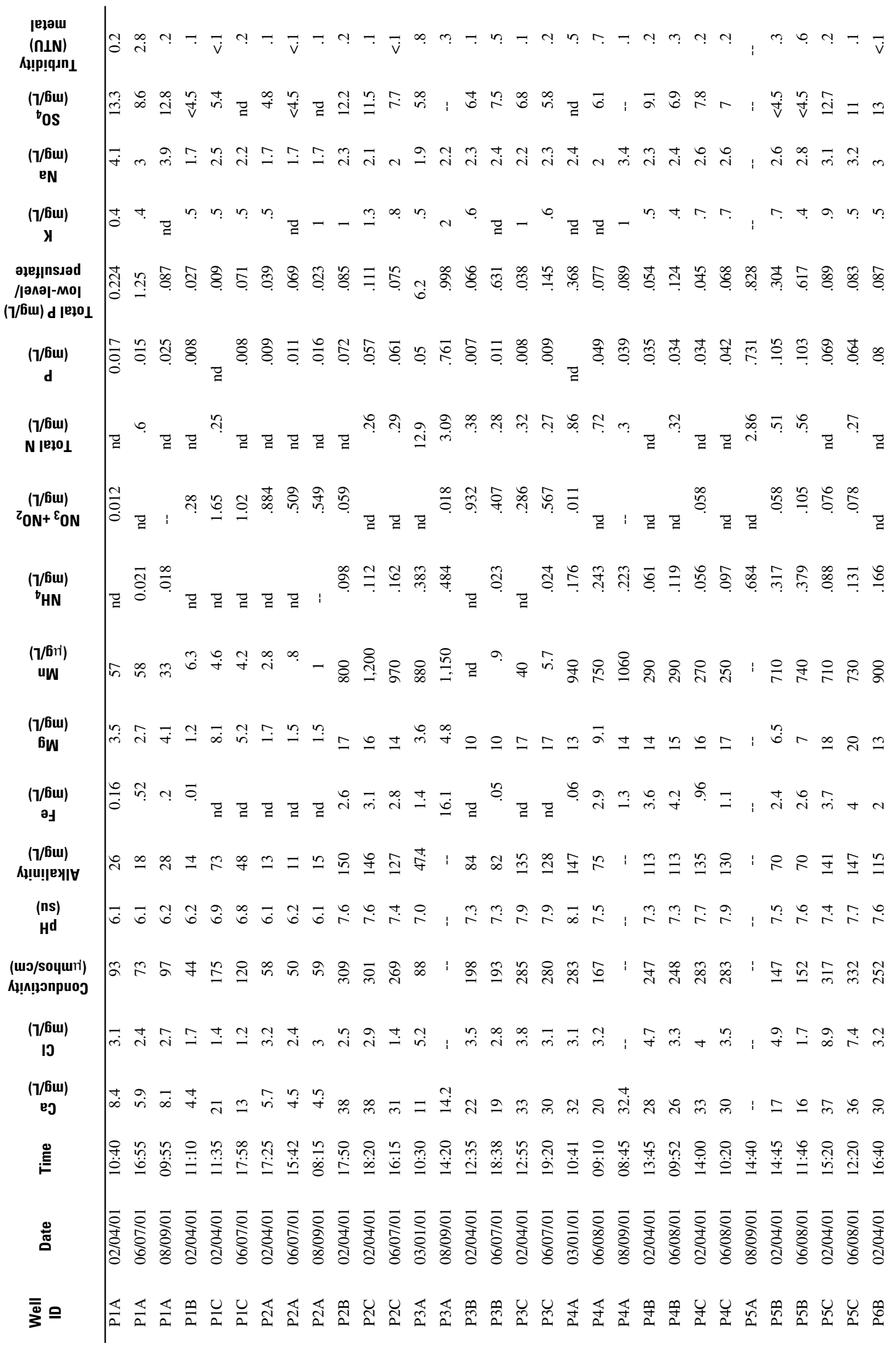




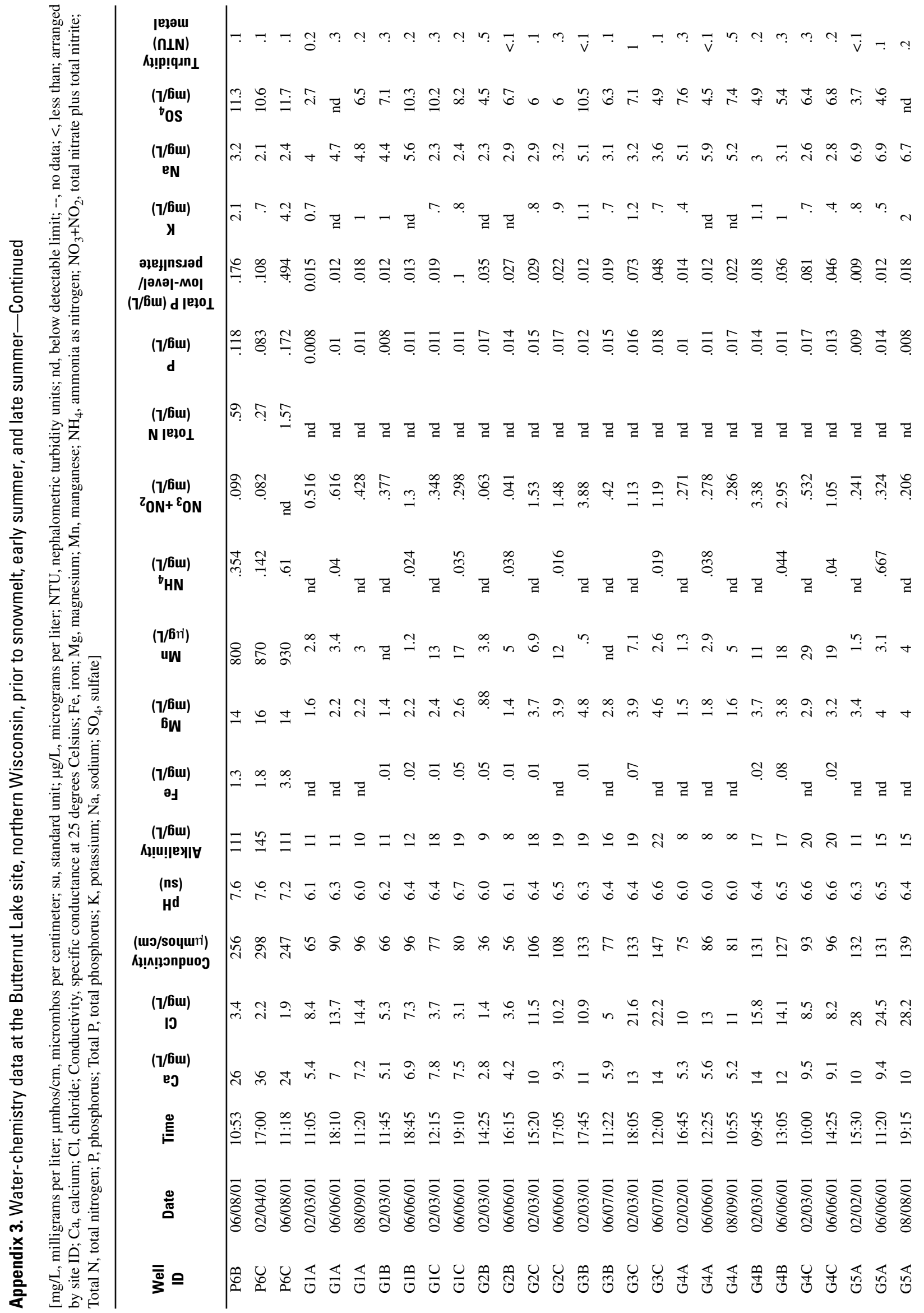




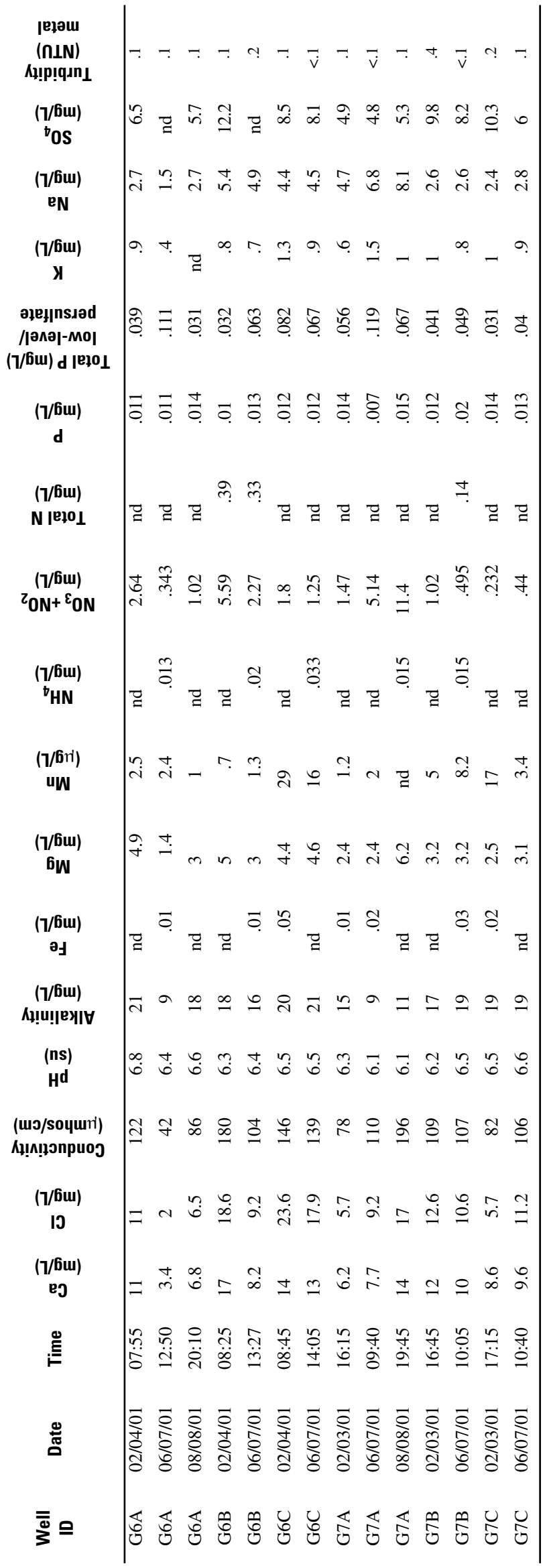




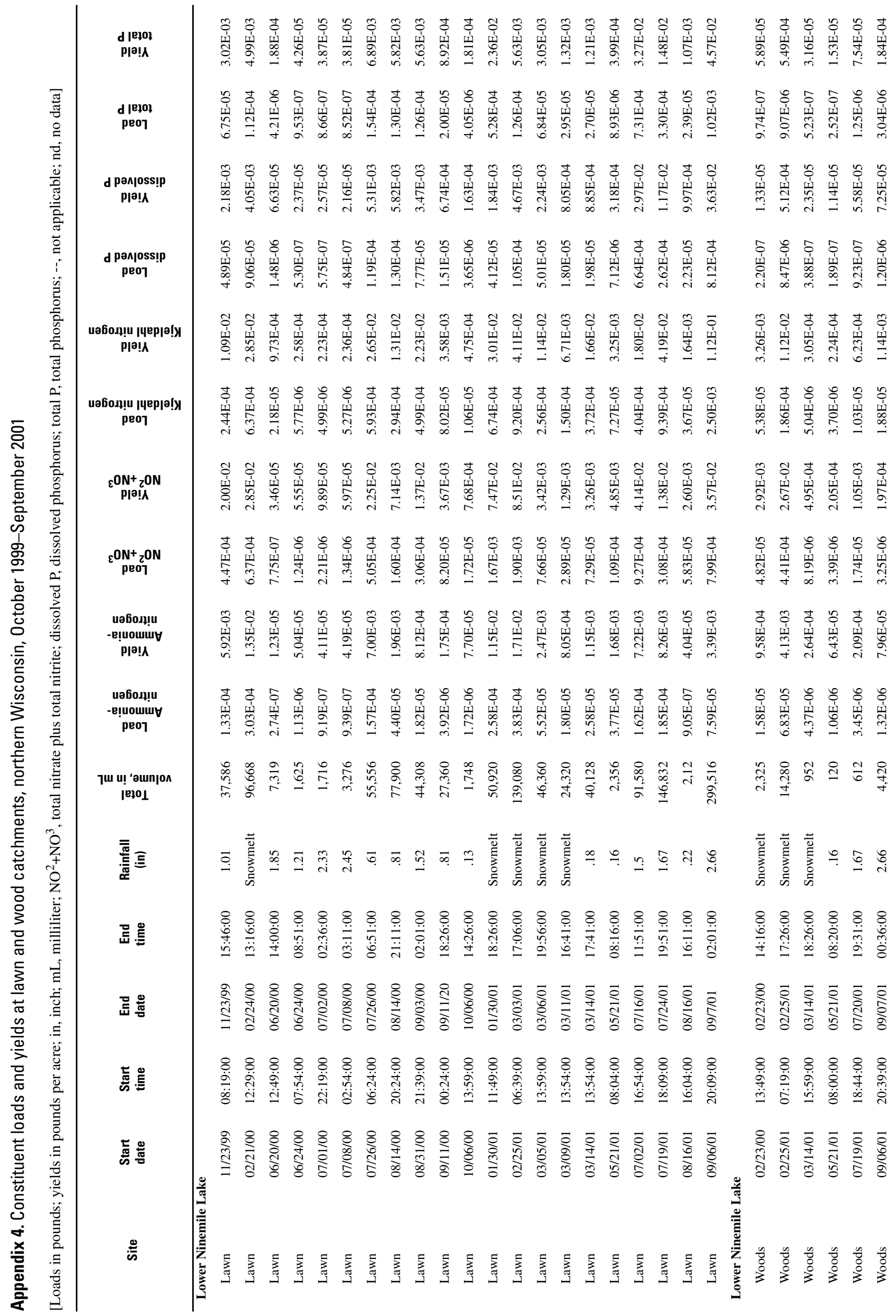




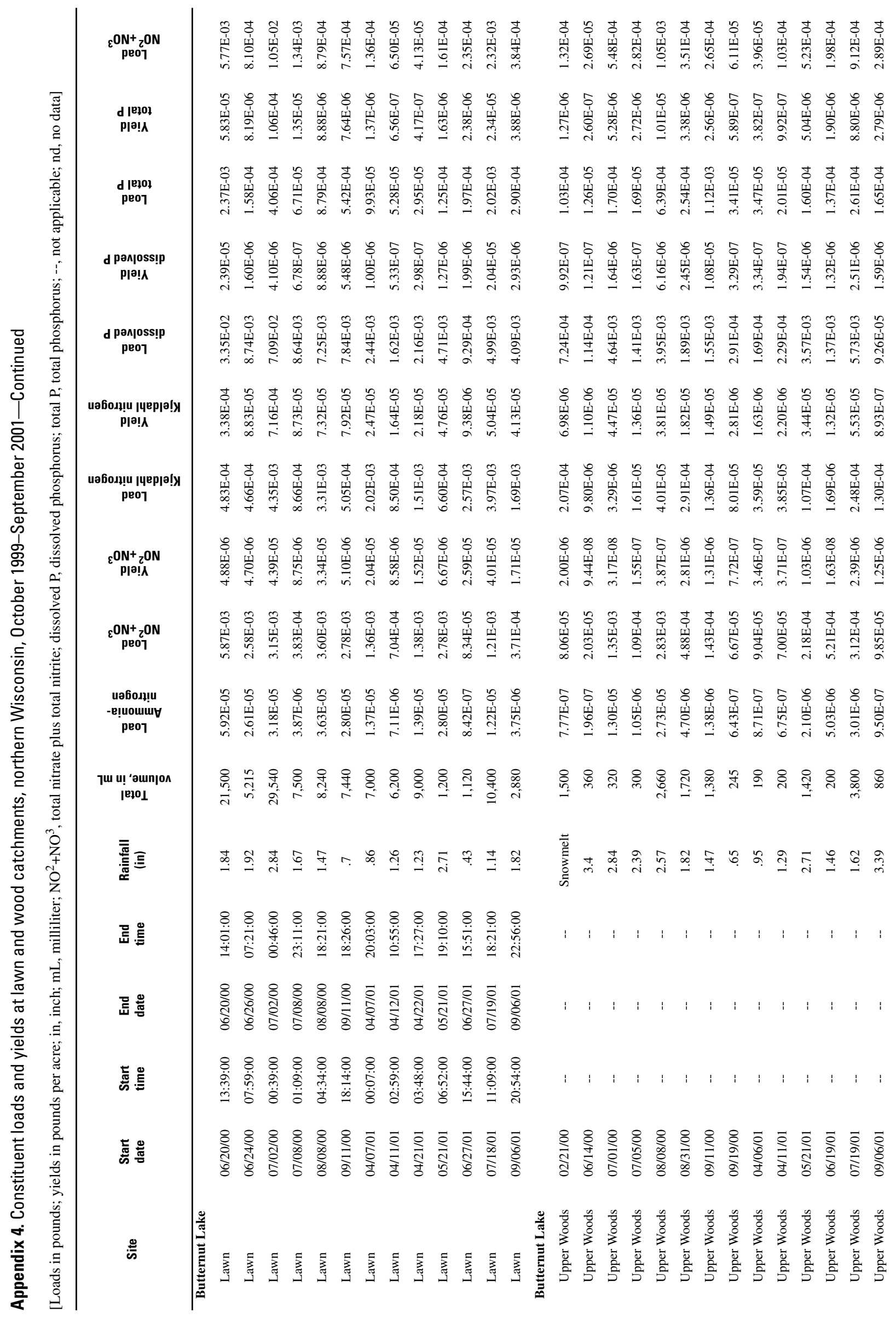




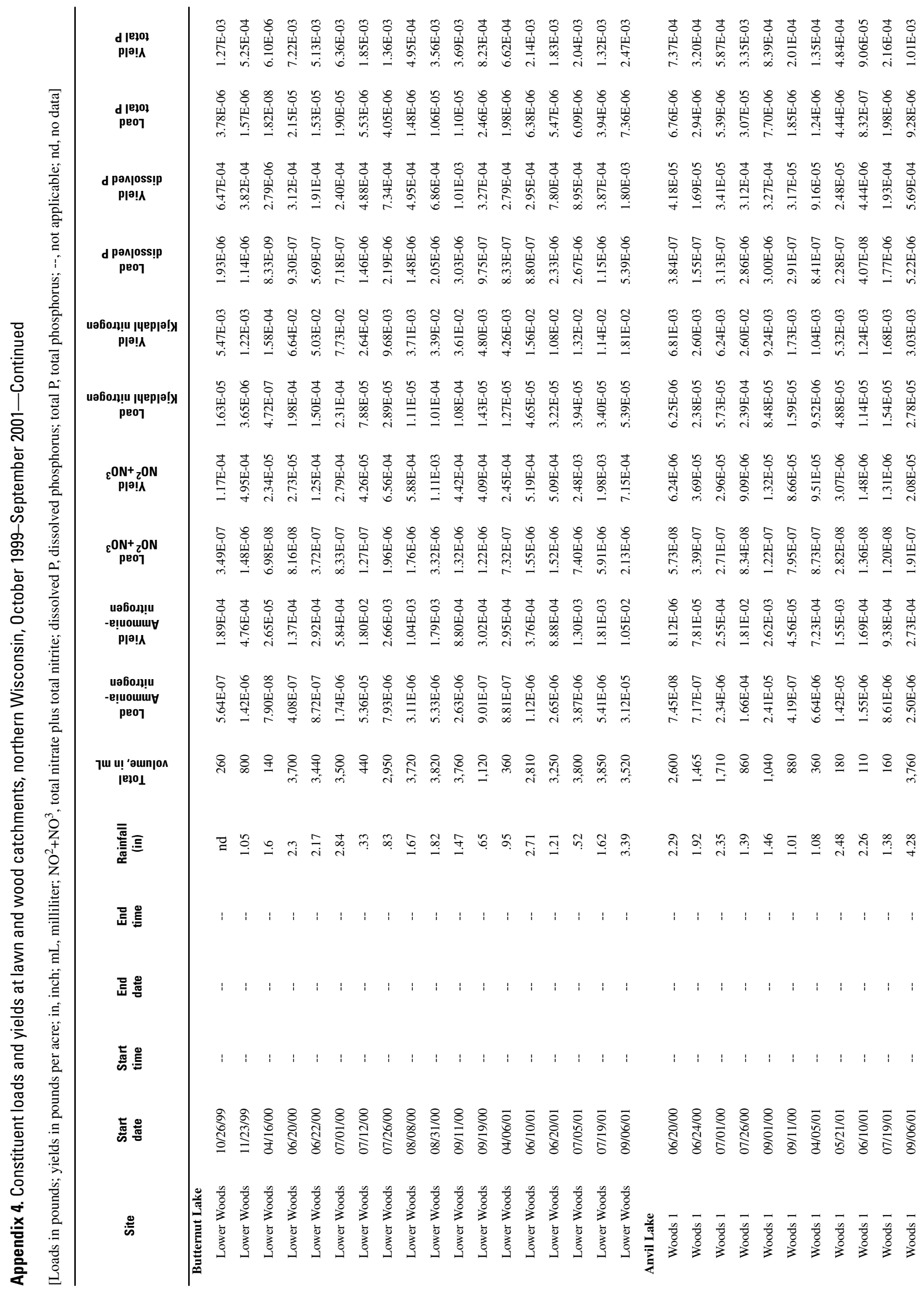




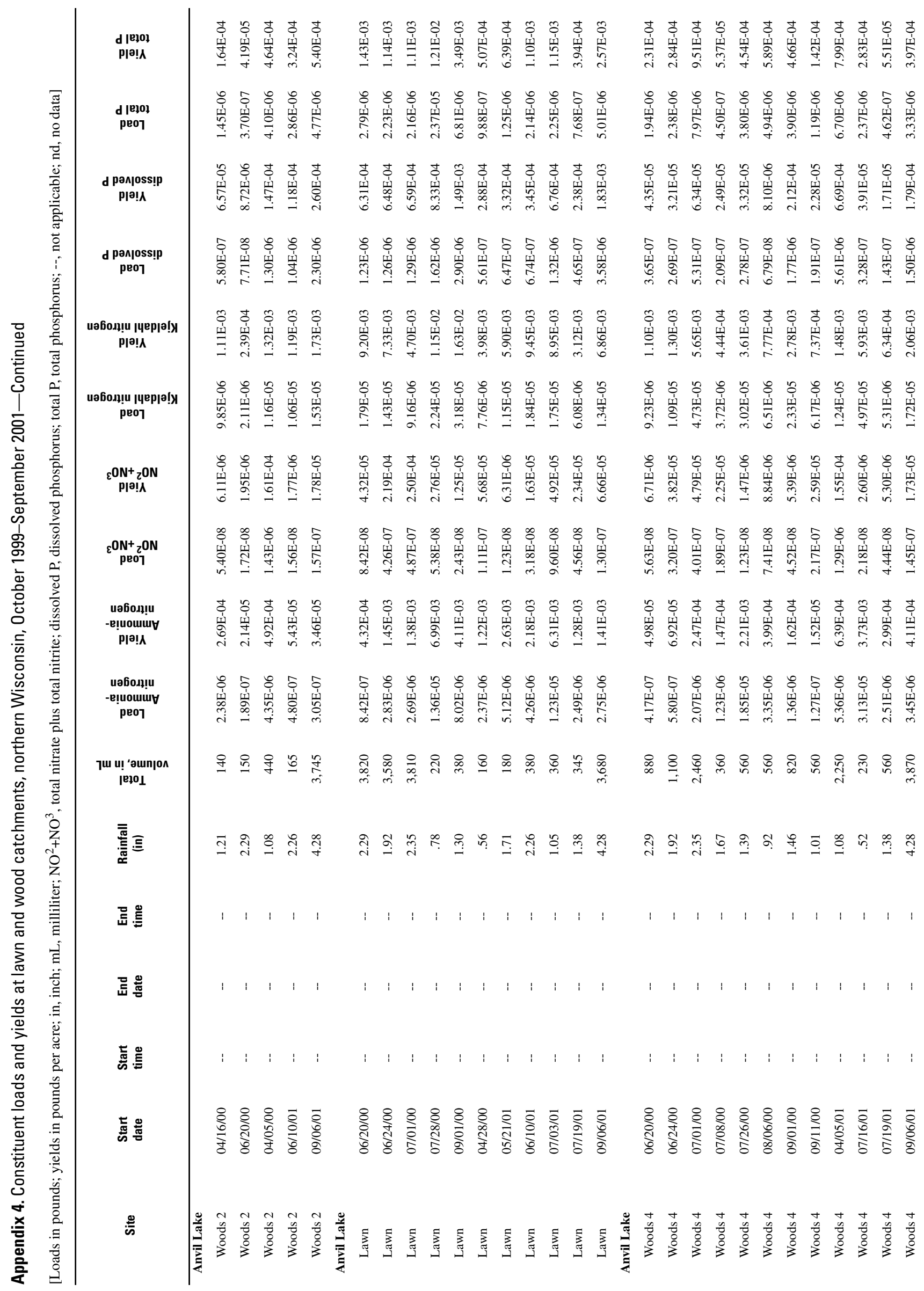


